\title{
KAPITALENS UDVIKLINGSFASER OG -TENDENSER I VESTTYSKLAND 2. DEL
}

Elmar Altvater, Jürgen Hoffmann, Wolfgang Schöller og Willi Semmler.

\section{Forsøg på en fremstilling af kapitalakkumulationens empiriske forløbsform}

\section{Indledning: Disposition og fremstillingens grænser}

I første del af denne artikel har vi først og fremmest diskuteret de metodiske problemer, der opstår ved analysen af udviklingstendenserne i et kapitalistisk land. Vi har fors $\varnothing \mathrm{gt}$ at bestemme forholdet mellem de marxske kategorier og den borgerlige statistiks begreber, at diskutere forklaringsværdien af indikatorer for den fremtrædende overflade i forhold til tilgrundliggende lovmæssigheder, og at vise problemet med analysen af en kapitalistisk nationalstat i sammenhæng med verdensmarkedsudviklingen. I den følgende 2. del af artiklen vender vi os mod selve den historiske analyse. Historisk analyse kan ikke betyde, at kapitalakkumulationsprocessens faktiske forløb nu skal fremstilles i alle detaljer, dvs. kapitalforholdets reproduktion, altså modsigelsen mellem lønarbejde og kapital i alle dens dimensioner. Vi har således pålagt os selv en begrænsning, for så vidt som enkelte aspekter af kapitaludviklingen behandles mere udførligt end andre; ja mange aspekter vil endog falde ud af vor fremstilling, ikke fordi de forekommer os uvæsentlige, men kun fordi vi skridt for skridt formår at oparbejde kendskab til problemerne. I det videre arbejde vil vi koncentrere os om de problemer, der står tilbage.

En sådan fremgangsmåde er naturligvis betænkelig, netop når det drejer sig om at drage politiske konsekvenser af en analytisk vurdering. Alligevel mener vi, at vores analyse er i stand til at skitsere den ramme, inden for hvilken kapi-

* Oversættelse af: Wolfgang Schoeller, Willi Semmler, Jürgen Hoffmann og Elmar Altvater: Entwicklungstendenzen des Kapitalismus in Westdeutschland, i: Probleme des Klassenkampfs nr. 16, 1974, s. 55-149. Artiklens første del blev bragt i KURASJE nr. 12, 1975, s. 26-54. 
taludviklingen i de næste år vil bevæge sig, den ramme indenfor hvilken også de taktiske overvejelser i lønarbejderklassens organisationer foregår. I den forbindelse vil vi lægge vægt på at tydeliggøre det - på den vesttyske venstrefløj for det meste - meget uspecifikt anvendte begreb om »kapitalens valoriseringsvanskeligheder «, der ifølge denne sprogbrug for det meste »vokser« og »skærpes «. Med dette formål vil denne artikels hovedgenstand være en indgående unders $\varnothing$ gelse af udviklingen i den vesttyske kapitals profitrate, af de faktorer, der har indflydelse på denne, og af deres betydning for kapitalakkumulationen. Vi vil altså i det væsentlige unders $\emptyset$ ge de objektive udviklingstendenser, der er bestemmende for kapitalforholdet, hvorimod betingelserne for arbejderklassens udvikling kun berøres periferisk i denne artikel ${ }^{1}$.

Dispositionen for denne artikel følger dels udviklingens kronologi, dels retter den sig efter systematiske synspunkter. Ved unders $\varnothing$ gelsen af profitratens udviklingstendenser går vi kronologisk frem, idet vi unders $\emptyset$ ger de faser, der på grundlag af den almene tendens (jvf. figur 3) aftegner sig i deres historiske rækkefølge. Efter fremstillingen af de almene udviklingsbetingelser vil vi undersøge, hvilken betydning det har haft for den vesttyske kapital at blive integreret $\mathrm{i}$ verdensmarkedet. I tilslutning hertil vil der blive fremsat nogle bemærkninger om statens rolle i den vesttyske kapitalismes udviklingsproces; i denne sidste del vil der kun blive fremlagt en foreløbig vurdering, der i det videre arbejde vil blive forfinet. I et af de næste PROKLA-hæfter (17/18) vil der i dette øjemed blive offentliggjort et forklaringsfors $\varnothing \mathrm{g}$ på den nuværende inflation.

Vi begrænser altså bevidst rækkevidden af vores undersøgelse til analysen af profitratens vigtigste bestemmelsesfaktorer og konsekvenserne af deres ændringer for kapitalakkumulationsbevægelsen. Når vi i det følgende forsøger at påvise de kapitalistiske udviklingstendenser med empirisk materiale, så vil vi naturligvis ikke dermed empirisk bevise den marxske teori. For værdibevægelsens former er ikke operationaliserbare, empirisk testbare og verificerbare ved hjælp af foreliggende statistisk materiale i den positivistiske videnskabsforståelses betydning. ${ }^{1 \mathrm{a}}$

1. Vi henviser i denne sammenhæng til de forskellige arbejder af Redaktionskollektiv Gewerkschaften, der er offentliggjort i PROKLA. Jfr. også den nyeste udgivelse af Projekt Klassenanalyse, Materialien zur Klassenstruktur der BRD. Zweiter Teil: Grundriss der Klassenverhältnisse (1950 bis 1970), Westberlin 1974. Dette arbejde fremkom kort før redaktionsafslutningen på denne artikel, så det har ikke været muligt at gå udførligt ind på den. Mens Projekt Klassenanalyse (PKA) fors $\varnothing \mathrm{ger}$ at forklare klasseforholdene og deres indre opdeling i overensstemmelse med de af Marx udledte selvstændiggjorte former ved hjælp af materiale fra den borgerlige statistik og på den måde betoner det strukturelle aspekt, går vi i vores undersøgelse ud fra akkumulationsteorien. PKA's bemærkning om kapitalakkumulationens historiske udvikling (s. 49-65) i Tyskland/Vesttyskland er i øvrigt lige så utilstrækkelig som vores henvisning til konsekvenserne af kapitalakkumulationens modsigelser for samfundets klasseopdeling.

1a. Angående forholdet mellem teori og empiri er fornylig udkommet Friedrich Eberle og Eike Hennig, Anmerkungen zum Verhältnis von Theorie und Empirie, in: Gesellschaft, Beiträge zur Marxschen Theorie 2, Frankfurt 1974, s. 7-110. Idet de henregner fremstillingen af »kapitalen i almenhed « til »strukturhistorie « og Marx' politiske skrifter til »begivenhedshistorie«, må de på forhånd erklære alle forsøg på formidling mellem værdibevægelsen 
Vi kan kun illustrere de værdikategorier, som det drejer sig om her, og kun med hvilke den historiske akkumulationsprocesses modsigelser i Vesttyskland kan bringes på begreb. Den egentlige vanskelighed i den forbindelse består i at gennemføre illustrationen ved hjælp af systematisk og hensigtsmæssigt udvalgte kategorier og materiale og at fortolke den borgerlige statistiks empiriske materiale meningsfuldt ved hjælp af den marxske teori.

Således går det til, at vi i denne fremstilling så at sige bevæger os på »dobbelt grund «: Når vi benytter den borgerlige statistiks empiriske materiale, befinder vi os helt inden for den borgerlige $\varnothing$ konomis begrebsramme; derimod lægger vi den marxske teori til grund ved afledning af tendensudsagn. Denne fremgangsmåde kan ikke undgås; i første del af denne artikel har vi givet en begrundelse for den ${ }^{1 b}$. Vor vigtigste tese, som vi indgående har begrundet (i KURASJE 12), er antagelsen om, at der over længere tidsrum er samme bevægelsesretning for de værdikategorier, der fremtræder på den empiriske målbare overflade. Det drejer sig derfor f.eks. ikke om at udregne profitratens aktuelle størrelse. Når vi beregner kapitalrentabilitetens udvikling ud fra en korresponderende størrelse i den borgerlige statistik, så kan man for hvert år angive et exakt procenttal. Dette procenttal har kun tilnærmelsesvis noget at gøre med profitratens aktuelle højde. Alligevel går vi ud fra, at kapitalrentabilitetens bevægelsesretning i det store og hele også betegner profitratens bevægelsesretning. Udfra denne synsvinkel forekommer beregningen af kapitalrentabiliteten os at være vigtig: den giver ikke oplysning om den aktuelle størrelse, men derimod om profitratens bevægelsesretning.

Lignende kan siges om komponenterne i såvel profitraten som i kapitalrentabiliteten. Under hensyntagen til de fremførte begrænsninger - kun at ville angive værdikategoriernes bevægelsesretning - kan man for de komponenter, der indvirker på profitraten finde »korresponderende « kategorier i den borgerlige statistik. Når vi i det følgende udarbejder en liste over de korresponderende

og dens nødvendige såvel som historiske fremtrædelsesformer som håbløse. Men dermed definerer de den marx'ske teori de facto som irrelevant for begribelsen af historiske begivenheder eller endog for udarbejdelsen af politiske taktiker. Deres tiltro til den borgerlige empirisme kompleteres på denne måde med rekonstruktionen af en elfenbens »marxisme«. Til slut i den lange artikel indrømmer de »at tvivle for meget af mistanke«. På trods af den på mange punkter uretfærdige mistanke har de ret i deres appel »endelig (!) at omfatte de centrale metodiske spørgsmål i forsøget på rekonstruktion af den marxske teori.« Os forekommer kun dette »endelig « at være en smule overdrevet. For diskussionen om forholdet mellem væsen og fremtrædelse, om afledningen af overfladen, om anvendeligheden af statistiske indikatorer osv, som den (i ofte polemisk form) i lang tid er blevet ført inden for de vesttyske venstregrupper, er netop den fordrede diskussion af centrale metodiske spørgsmål. Blot har forfatterne ikke det mindste kendskab til denne diskussion på trods af en overvældende litteraturopvisning.

1b. Lignende vanskeligheder har også Projekt Klassenanalyse i omtalte bog og Helmut Zschocke, Kapitalstruktur und Kapitalverwertung in der BRD-Industrie, Berlin (DDR) 1974, hvis ansats lige som vores også er akkumulationsteoretisk orienteret. Vi vil berøre den endnu nogle steder i teksten. 
begreber, så sker det kun med den advarsel, at det på ingen måde drejer sig om transformation af marxske begreber til borgerlige. Den marxske teori er ikke ét i forhold til den borgerlige teori anderledes videnskabelig sprogsystem, der simpelthen kan oversættes til det borgerlige videnskabssprog. Den marx'ske teori er jo netop kritik af denne videnskab, især den borgerlige $\varnothing$ konomi. ${ }^{1 \mathrm{c}}$ Når den historiske analyse af den kapitalistiske økonomis bevægelse skal bestemme denne bevægelse som en empirisk begribelig proces på grundlag af statistisk materiale, kan den ikke give afkald på at fremstille modsigelsesmomenterne og kapitalakkumulationens bevægelsesretning.

Hvis vi tager hensyn til alt dette og desuden ikke glemmer afgrænsningerne i første del, så kan bevægelserne - ikke de absolutte størrelser - i de følgende statistiske kategorier anvendes som indikatorer for værdibevægelsens kategorier: Kapitalintensiteten (bruttoanlægsformue pr. arbejdsplads, $\mathrm{K} / \mathrm{L}$ ) indicerer omtrentligt kapitalens tekniske sammensætning; kapitalproduktiviteten (nettoproduktionsværdi i forhold til bruttoanlægsformue, $\mathrm{Y} / \mathrm{K}$ ) indicerer forholdet mellem levende og dødt arbejde ( $\mathrm{v}+\mathrm{m} / \mathrm{c})$; arbejdsproduktiviteten (nettoproduktionsværdi pr. arbejder, Y/L) indicerer arbejdets produktivkraft; lønkvoten (andel af løn og gage i forhold til nettoproduktionsværdien, $\mathrm{W} / \mathrm{Y}=\mathrm{w}$ ) indicerer arbejderklassens andel $\mathrm{i}$ det af den producerede værdiprodukt $(\mathrm{v} / \mathrm{v}+\mathrm{m})$ - herved abstraheres der foreløbigt fra forskellen mellem produktive og uproduktive arbejdere; forholdet mellem profitter og lønninger, (nemlig 1-w/w) indicerer merværdiraten. Og endelig kapitalrentabiliteten

$$
\left(\mathrm{pi}=\frac{\mathrm{Y} / \mathrm{L}(1-\mathrm{w})}{\mathrm{K} / \mathrm{L}}\right)
$$

indicerer profitraten

$$
\left(\mathrm{p}^{\prime}=\frac{\mathrm{m} / \mathrm{v}}{1+\mathrm{c} / \mathrm{v}}\right)
$$

Vi understreger endnu engang, at der hermed ikke foregives at vare foretaget nogen transformationer, men at de borgerlige kategoriers målelige bevægelser kun kan give oplysninger om det, som selve værdibevægelsen har fuldbyrdet. Dette implicerer imidlertid yderligere en vanskelighed, nemlig den sproglige beherskelse af disse to planer hhv. kategorisystemer. Vi har bestræbt os på altid at bruge de marxske kategorier, når vi forsøger at give en interpretation af værdibevægelsen; vi anvender altid statistikkens begreber, når vi fremstiller og

1c. Det er ikke kun kritik i betydningen ideologikritik, men materialistisk kritik. Dette betyder, at den i kritikken inddrager det historiske grundlag, på hvilket den borgerlige videnskab, specielt den borgerlige økonomi, opstår. Afdækningen af nødvendigheden af de kategorier, inden for hvilke den borgerlige videnskab bevæger sig, sker gennem analysen af det borgerlige samfunds indre natur, dels bevægelseslove og betingelserne for dets ophævelse. Ikke det kritiske aspekt, som sådan, men den kendsgerning, at den marxske teori viser ud over det borgerlige samfund, altså en revolutionsteori, gør det umuligt at transformere den til andre videnskabssprog. 
interpreterer statististiske indikatorer for udviklingsprocessen. Denne skarpe adskillelse kan dog ikke opretholdes i alle passager i fremstillingen.

Med det empiriske bevis for, at kapitalrentabiliteten siden midten af 50'erne tendentielt er faldet i Vesttyskland, er på ingen måde den marxske teori om profitratens tendentielle fald empirisk bevist. Det drejer sig heller ikke for os om at bevise det. Men vi har villet påvise, at kun på den måde som vi har foretaget empirisk unders $\varnothing$ gelse af udviklingsprocessen i et kapitalistisk land $i$ et konkret tidsrum, er det muligt at bringe udviklingstendenserne og deres modsigelser på begreb med de marxske kategorier. ${ }^{2}$

Dermed skulle det være klart, at kontroversen om loven om profitratens tendentielle fald skyder forbi målet, for så vidt kontrahenterne henviser til det empiriske materiale. Da imidlertid de empirisk orienterede kritikere af loven om profitratens tendentielle fald har opnået en meget stærk politisk betydning, vil vi indledningsvis kort berøre dette problem uden at tage hensyn til alle de argumenter, der angriber den teoretiske konsistens af loven. ${ }^{2 a}$

Hos de empirisk orienterede kritikere kan vi udskille tre argumentationslinier:

1. Den $f \varnothing r s t e$ position $^{3}$ går ud fra det »empiriske faktum «, at der er en langsigtet konstant for indkomstfordeling, for kapitalkoefficienten (f.eks. kapitalproduktiviteten) og en tilsvarende konstant for profitraten. For kapitalens organiske sammensætning er der tilsvarende også en langsigtet konstant.

Ifølge denne position, der ofte henholder sig til empiriske tendenser i Vesttyskland for tidsrummet før 1960, har enhver afvigelse fra den postulerede konstante proportion (under langsigtede akkumulationsfaser og under den industrielle cykel) tilbøjelighed til at genoprette de gamle proportioner gennem tilsvarende modreaktioner.

Schmitt-Rink henholder sig til en påstået empirisk konstant for disse makroøkonomiske størrelser i sin kritik af loven om den faldende profitrate, når han skriver: »Marx' antagelse, at kapitalkoefficienten stiger m.h.t. mekaniseringsprocessen, at kapitalproduktiviteten falder - vil sige: at kapitalintensiteten

2. Dette krav behøver to vigtige afgrænsninger: For det første bliver teoretiske kontroverser ikke afgjort med en fremstilling af historiske forhold i et kapitalistisk land. For det andet er selve vores empiriske fremstilling endnu begrænset. Når vi eksempelvis beregner profitraten, så benytter vi især tal fra industrien. Brancheprofitrater i andre områder af $\emptyset$ konomien bliver ikke beregnet her. Men med denne fremgangsmåde abstraheres fra udligningsbetingelserne til gennemsnitsprofitraten, fra mulige værdioverførsler mellem sektorerne. Derudover har vi endnu ikke overvejet den særskilte situation for den vesttyske kapital i forhold til andre kapitalistiske lande. For at få et tilfredsstillende overblik over tendenserne for kapitalakkumulationen, ville dette dog være nødvendigt. Allerede ud fra disse indskrænkninger er det nødvendigt at advare mod overfortolkninger af det materiale, som vi har fremlagt og analyseret.

2a. Som repræsentanter skal her nævnes: Paul M. Sweezy, Theorie der kapitalistischen Entwicklung, Köln-Deuz 1959 og Natalie Moszkowska, Das Marxsche System - Ein Beitrag zu dessen Ausbau, Berlin 1929.

3. Denne position repræsenterer frem for alt Cambridge-skolen. Jvf. arbejderne af Joan Robinson og Nicholas Kaldor. 
stiger stærkere end arbejdsproduktiviteten, - bliver gendrevet af tilgængelige resultater fra empiriske unders $\varnothing$ gelser: Kapitalkoefficienten, kapitalproduktiviteten viser sig at være bemærkelsesværdig konstant $^{4}{ }^{4}$

Denne »konstant « gælder ganske vist kun - som vi vil vise - indtil første halvdel af 60'erne. De empiriske unders $\varnothing$ gelser viser for 60'erne og 70'erne ikke længere en konstant for disse størrelser. Schefold vil på sin side give et indblik i den empiriske konstant for indkomstfordeling og profitrate med argumentet, at »klasserne på en eller anden måde er kommet »overens « med dette forhold $\aleph^{5}$. Tendensen til den konstante proportion følger hos Schefold der med sine argumenter knytter an til Cambridge-skolen - af, at arbejdsgiverne altid opnår en »tilfredsstillende profitrate«. Stiger den organiske sammensætning og lønkvoten (ved knaphed på arbejdskræfter) og falder derfor profitraten i boom'et, så formindskes investeringerne, fordi profitraten ikke længere »anses for tilfredsstillende«. Stagnationen bereder omvendt igen en højere profitrate i den forstand, at der ventes sålænge, at betingelserne for en tilfredsstillende profitrate udvikles igen. Falder profitraten på den anden side, fordi reallønnen stiger hurtigere end produktiviteten, »så falder profitraten enten med det samme og udløser en krise, eller det bliver plausibelt, at den organiske sammensætning må stige, hvad kun er et andet udtryk for, at der finder en stadig substitutionsproces sted, der... endelig må munde ud i profitratens fald og krisen $\ll^{6}$. Hverken henvisningen til den påstået empiriske konstant for profitratens komponenter eller de teoretiske forklaringer på modreaktioner, der igen efter afvigelserne skal etablere proportionens konstant, forekommer os at have et tilstrækkeligt fundament. Vi vil vise at de empiriske

4. G. Schmitt-Rink, Kapitalintensität und Kapitalrentabilität im Marxschen Model. Über Konsistenz und Relevanz des Gesetzes vom tendenziellen Fall der Profitrate, i: Schmollers Jahrbuch 1967, s. 139.

5. B. Schefold, Wert und Preis in der marxistischen und neokeynesianischen Akkumulationstheorie, i: Mehrwert, Hefte 2, 1973, s. 164.

6. B. Schefold, op.cit., s. 165 f. Bag denne (først og fremmest) indlysende overvejelse står en meget formalistisk model for den kapitalistiske akkumulationsproces. Ifølge den bliver den gamle (værdi) forhold altid reetableret i krisen - selv om det indrømmes, at de stoflige, produktionsteknologiske forhold fuldstændigt må ændres. Deroverfor sætter vi med Eugen Varga, der skriver: »Gentagelsen af cyklen betyder imidlertid ikke sammenkædningen af kvalitativt ensartede processer. Den nye cyklus er samtidig et trin i kapitalismens historie, der driver den et stykke mod sin ende. Enhver krise tilintetgør et stort antal af små kapitalister, betyder et yderligere fremskridt mod centralisation: ethvert opsving betyder et stort nyanlæg af fixe kapital«. Eugen Varga, Die Krise des Kapitalismus und ihre politischen Folgen, Fankfurt und Wien 1969, s. 208. Schefold negligerer forskellen mellem kapitalistisk udviklingslov, dens tendentielle gennemslag og tendensens cykliske forløbsform. Det sidste bliver hypostaseret af ham. Kapitalismen får derved evighedskarakter, da det er et system, der nødvendigvis stabiliserer sig selv. De politiske konsekvenser, som Schefold og de andre repræsentanter for Cambridgepositionen drager, bliver nødvendigvis moralske. Dette aspekt bliver udførligt kritiseret af Robert Rowthorn, Marxism and the Capital Theory Controversy, i: Bulletin of the Conference of Socialist Economists, 2,2 Autumn 1972, s. $22 \mathrm{ff}$. 
fakta taler imod denne konstant. Derudover kan den teoretiske og empiriske problemstilling i henseende til den kapitalistiske akkumulationsproces ikke være spørgsmålet om konvergens til ligevægtsreproduktion, (et typisk spørgsmål for den borgerlige ligevægtsteori) men det må derimod være at forklare de tendenser, der netop producerer uligevagt og modsigelser i den kapitalistiske reproduktionsproces.

2. En anden position ${ }^{7}$, som Gillman er repræsentativ for, tvivler på, at den marxske forklaring af kapitalens voksende organiske sammensatning er rigtig i empirisk forstand for alle faser af den kapitalistiske udvikling. Gillmans unders $\varnothing$ gelse, der egentlig beror på hypoteser af nogle amerikanske økonomer (bl.a. Kuznet), ifølge hvilke den amerikanske væksts- og akkumulationsproces siden 20'erne overvejende har været bestemt af kapitalbesparende teknisk fremskridt, er den grundigste empiriske undersøgelse af dette problem. Gillman kommer i denne undersøgelse til den slutning: »Mens Marx' lov om profitratens faldende tendens gjaldt for kapitalismen i det stadium, hvor den var kendetegnet af hurtig udvikling og mekanisering, ophører dens gyldighed skridt for skridt, eller den gør sig kun svagt gældende, når industrien er fuldt udviklet og mekaniseret. Dette må være sådan, lyder argumentet, fordi kapitalismens transformation fra sit håndværksmæssige trin til sit industrialiserede trin - fra hånd - til maskinfabrikation - samtidig betyder dens transformation fra den lille position, der er underlagt konkurrencebetingelserne, til den overvejende monopolistiske storproduktion. Har disse betingelser engang været fremherskende, så antager de modgående tendenser, som Marx taler om, en ny, kvalitativ intensitet. Nye former for teknologisk innovationer og ledelsesformer for $\varnothing$ konomien er blevet udviklet, hvorved merværdiraten er steget, men uden en kvantitativ stigning i den konstante kapital, som i fortiden havde en tilbøjelighed til at hæve kapitalens organiske sammensætning «. Gillmans hovedargument mod en stigning i den organiske sammensætning siden $20^{\prime}$ erne er altså »muligheden for produktion af en yderligere merværdi uden en modsvarende kompletering af den investerede kapital ${ }^{8}{ }^{8}$

I den borgerlige definition af det tekniske fremskridt hed det: Stigning i output eller arbejdsproduktivitet uden stigning i kapitalindsats pr. arbejdskraft (neoklassisk definition) eller stigning i output uden stigning i kapitalindsats pr. outputenhed (postkeynesiansk definition). Vi kommer nedenfor tilbage til dette problem under analysen af kapitaludviklingen i BRD. Der er blevet fremlagt en række undersøgelser af amerikanske $\varnothing$ konomer, der påstår at have fastlagt en tendens til kapitalbesparende teknisk fremskridt siden 20'erne i USA.

I de marxske begreber betyder Gillmans tese: Stigning i arbejdsproduktivitet (og tilsvarende merværdiraten) uden tilvækst i det døde arbejde i forhold

7. J. M. Gillman, Das Gesetz des tendenziellen Falls der Profitrate, Frankfurt und Wien 1969.

8. J. M. Gillman, op.cit., s. 73. 
til det levende arbejde $\mathrm{c} /(\mathrm{v}+\mathrm{m})$, eller uden tilvækst i den organiske sammensætning c, selvom også den tekniske sammensætning kan stige. Den empiriske udvikling i Tyskland viser også, at den af Gillman og af andre påståede tendens til kapitalbesparende innovationer og til en uforandret eller stigende kapitalkoefficient (eller en uforandret eller stigende kapitalproduktivitet) imidlertid ikke lader sig generalisere - selvom denne tendens fasevis må sætte sig igennem. (I vores figur 1 sammenlignes den stigende kapitalproduktivitet i Tyskland efter verdenskrisen og i figur 2 efter den anden verdenskrig). Denne form for teknisk fremskridt, der er fastlagt af borgerlige og marxistiske økonomer, var virkelig fremherskende i 50'erne i Forbundsrepublikken, men forsvinder i 60'erne.

3. En tredje gruppe af kritikere, der ligeledes implicit forudsætter den organiske sammensætnings konstans i tid, kritiserer en anden komponent af profitraten, nemlig mervardiraten eller lønkvoten. If $\varnothing$ lge disse kritikere er den relevante indflydelse på profitraten i efterkrigsudviklingen (særlig i 60'erne) ikke udgået fra den tendentielle stigning i det døde arbejde i forhold til det levende arbejde, altså fra en stigning i kapitalens organiske sammensætning, men den er snarere udgået fra ændringen af fordelingsforholdene mellem lønarbejde og kapital til fordel for lønarbejderne. (Denne position forsvares kraftigt af Glyn/ Sutcliffe i deres bog »British Capitalism, Workers and the Profits Squeeze « - vi har i PROKLA 14/15 diskuteret denne bog). ${ }^{9}$ På grundlag af vores formel for profitraten og kapitalrentabiliteten (s. 8) er denne argumentation let at tilbagevise. Falder merværdiraten i vores formel for profitraten, må profitraten falde eller udtrykt i statistiske begreber, stiger lønandelen i nettoproduktionsvolumet eller den totalsamfundsmæssige lønkvote, så må kapitalrentabiliteten falde. Arbejdernes lønstrejker og fagbevægelsens stigende lønforhandlingsmagt i efterkrigstiden, bliver i denne interpretation til den umiddelbare og afgørende årsag til den faldende kapitalvalorisering. Forudsat er her kun, at der kan opnås en reel omfordeling af indkomsten til ugunst for profitandelen ved lønstrejker og lønkrav.

Det empiriske fremtrædelsesbilled med en tiltagende lønandel af nettoproduktionsvolumen i anden halvdel af 60'erne i Vesttyskland synes at give disse kritikere ret. Stigningen i lønandelen af nettoproduktionsvolumen synes virkeligt i slutningen af 60'erne at have fået mere vægt i forhold til den aftagende tendens for kapitalrentabiliteten. Bortset fra den inflationære forfalskning af w og bortset fra den efter vort skøn problematiske ligesætning af lønkvoten (w) med merværdiraten, viser - og dette er den egentlige langsigtet tendens, som vi vil påvise - kapitalproduktiviteten på den anden side et kontinuerligt fald siden anden halvdel af 50'erne. Kapitalproduktiviteten fremstiller ganske vist først og fremmest et forhold af fysiske størrelser, men kan efter vore overve-

9. A. Glyn og B. Sutcliffe, British Capitalism, Workers and the Profits Squeeze, Harmondsworth 1972. 
jelser (i første del) interpreteres som forhold mellem værdier, nemlig som forholdet mellem det levende og det i produktionsmidler genstandgjort arbejde. (Omvendt repræsenterer kapitalkoefficienten forholdet mellem det døde og det levende arbejde). Denne tendens til fald for kapitalproduktiviteten antyder derfor en stigning i forholdet mellem det døde og det levende arbejde og - med hensyntagen til arbejdskraftens værdiforandring - en stigning i den organiske sammensætning (fremkaldt gennem den enorme »kapitalintensivering « $\mathrm{i}$ BRD). Den egentlige langsigtede årsag til kapitalvaloriseringens tendens til fald er derfor ikke så meget lønandelens stigning af nettoproduktet, men den kendsgerning, at produktivitetsstigningen i det mindste i BRD blev købt med en meget stærkere stigning i kapitalintensiteten og derfor med en virkelig stigning i den organiske kapitalsammensætning. Også denne tredje position forekommer os derfor hverken i teoretisk eller empirisk forstand at være holdbar.

\section{De historiske forudsætninger for det vesttyske »økonomiske mirakel«: Fascisme, anden verdens- krig og efterkrigstiden}

Man kan ikke foretage en analyse af den vesttyske kapitals akkumulationsbevægelse, uden at man tager hensyn til de historiske forudsætninger for det hurtige økonomiske opsving, som meget snart blev ideologiseret til »det tyske $\varnothing$ konomiske mirakel«. De gunstige betingelser for profitudviklingen efter den anden verdenskrig, som var grundlaget for den hurtige kapitalakkumulation, er blevet fremkaldt gennem verdenskrisen, fascismen, krigen og den umiddelbare efterkrigstid. For at forstå den vesttyske kapitalismes dynamik, må man altså unders $\varnothing \mathrm{ge}$ dens forhistorie. Det vil ske i det følgende afsnit.

\subsection{Den økonomiske verdenskrise}

Udgangspunktet for vor fremstilling er den $\varnothing$ konomiske verdenskrise ${ }^{10}$, ikke blot fordi denne krise har haft betydning for depressionens dybde og

10. Den verdens $\varnothing$ konomiske krise hører stadigvæk til den kapitalistiske udviklings uafklarede fænomener inden for den borgerlige økonomiske historie. Det kan ikke betale sig at gå ind på de diverse teorier og fremstillinger angående den $\emptyset$ konomiske verdenskrise. De forskellige borgerlige teorier er - immanent kritiseret - meget udførligt behandlet hos Gerhard Kroll, også Gottfried Haberler (Prosperität und Depression, Tübingen og Zürich 1955) fremstiller immanent teorierne for selv at sammenblande en eklektisk mixtur til forklaring af den verdens $\varnothing$ konomiske krise. Den stadigvæk - efter vores opfattelse og kendskab bedste historiske fremtilling af betingelserne, forløbet og de økonomiske såvel som politiske konsekvenser af krisen stammer fra Eugen Varga, Die Krise des Kapitalismus und ihre politischen Folgen, Frankfurt 
varigheden af den efterfølgende stagnationsfase for kapitalakkumulationen, men fremfor alt fordi krisen (som sådan) altid fremstiller et nyt startpunkt og skaber forudsætningerne for hele den videre udvikling - indtil den næste krise. På historisk enestående måde blev det her tydeligt, at kapitalen er blevet til en skranke for sin egen udvikling, selvom denne skranke for den borgerlige bevidsthed snarere forekom som katastrofen ${ }^{11}$ unddraget rationel forklaring end som det nødvendige resultat af tilspidsningen af modsigelserne i den kapitalistiske udvikling.

Enhver cyklisk krise er udtryk for kapitalens faldne valoriseringsmuligheder, der reducerer nyanlæg af kapital. Udvidelsen af den fungerende kapital er ikke længere tilstrækkelig til helt at beskæftige arbejderne og til at udnytte den bestående kapacitet af fixeret kapital i form af produktionsmidler. Således går det til, at arbejdsløshed og underudnyttelse af produktionskapaciteten bliver de to vigtigste fremtrædelsesformer for den kapitalistiske krise. Men i krisens konsekvenser er allerede anlagt muligheden for dens overvindelse: Varekapitalens prisfald - som det skete i hidtil ukendte dimensioner under den $\varnothing$ konomiske verdenskrise ${ }^{12}$ - devalorisering af den anlagte produktive kapital gennem konkurs, afskrivninger, (der bogføringsteknisk sanktionerede den fuldbyrdede devalorisering), selve den fysiske tilintetgørelse af varelagre og produktionsmidler, og en formindskelse af udlægget til varen arbejdskraft gennem den løntrykkende virkning af den millionstærke industrielle reservearme - alt dette måtte føre til, at kapitalens profitabilitet igen kunne tilvejebringes. Fordi udbytningsraten kunne stige gennem krisens disciplinerende virkning og den udlagte kapitalværdi kunne forringes gennem devaloriseringsprocessen. Da kapitalens valoriseringsgrad således egentlig skulle have forbedret sig, skulle det også kunne forventes, at der af krisen ville følge et nyt opsving for kapitalakkumulationen. Dette var dog på ingen måde tilfældet under den $\varnothing$ konomiske verdenskrise. Snarere gik den over i en stagnationsfase, der i USA varede indtil den anden verdenskrigs udbud ${ }^{13}$. Derfor er det ikke blot nødvendigt at forklare den $\varnothing$ konomiske verdenskrise, men det er også nødvendigt at undersøge den langvarige stagnationsperiode og dens national specifikke overvindelse.

und Wien 1969. Deri fortjener de artikler, der er skrevet fra 1930 til 1934 og den delvist gengivne bog »Die große Krise und ihre politischen Folgen - Wirtschaft und Politik 19281934, s. 88-370 særlig opmærksomhed. Jvf. også G. Kroll, Von der Weltwirtschaftskrise zur Staatskonjunktur Berlin 1958; M. Flamant, Jeanne Singer- Kérel, Modern Economic Crises, London 1970; Ernst Wagemann, Struktur und Rhythmus der Weltwirtschaft, Berlin 1931; Ch.

P. Kindleberger, Die Weltwirtschaftskrise (Geschichte der Weltwirtschaft im 20. Jahrhundert, Band 4), München 1973.

11. Jvf. dertil G. Lukacs, Geschichte und Klassenbewußtsein, Berlin 1923, s. 110-115.

12. Jvf. dertil de statistiske oplyninger i: Statistisehes Handbuch von Deutschland, München 1949, s. 463ff; også E. Varga op.cit.

13. Jvf. G. Kroll, op.cit. 20. kapital. 
Uden nu at gøre fordring på at give en forklaring, der tager hensyn til alle betingelserne for »den store depression « vil vi dog påpege tre væsentlige fremtrædende sammenhænge: ${ }^{14}$

For det første har den fixe kapitals stigende andel i den samlet udlagte konstante kapital ændret devaloriseringsprocessens karakter. Fixeringen af stigende kapitalmasser i stoflig form, kapitalmasser, der under flere omslagsperioder er fastlagt i produktionssfæren, må tvangsmæssigt ændre de former, under hvilke devaloriseringen af kapital fuldbyrdes i krisen som forudsætning for nyanlæg. Det problem, der her antydes, bliver i virksomheds $ø$ konomilæren alment betegnet som den »stigende fixomkostningsbelastning «, der formindsker $\emptyset$ konomiens tilpasningselasticitet ved vekslende afsætningssituationer. Under krisen har E. Schmalenbach allerede påpeget dette. Han slår fast, at de økonomiske forhold befinder sig »i overgangen eller ved tærsklen mellem den frie og den bundne $\varnothing$ konomi «. Han fører denne »systemforandring « tilbage til forskydningen mellem produktionsomkostningerne inden for virksomheden. »Det drejer sig netop om, at andelen af de proportionale omkostninger i produktionsprocessen er blevet mindre og andelen af de fixe omkostninger er blevet stadig større, så meget, at andelen af de fixe omkostninger til sidst blev bestemmende for produktionsudviklingen ${ }^{15}$. Derfor er stigningen i virksomhedsstørrelserne, stigningen i $k a$ pitalintensiteten og den nødvendige kontinuitet i produktionsforl $\varnothing$ bet som følge af den høje fixkapitalandel i de store virksomheder også det egentlige problem for de store kapitaler, der må akkumulere stadig større profitmasser alene for at kunne opretholde en engang opnået rentabilitet. Schmalenberg: »På utallige generalforsamlinger hører man bestyrelsen fremføre, virksomheden i dag ikke arbejder helt tilfredsstillende; men hvis endnu nogle maskiner blev anskaffet og der blev foretaget yderligere udvidelser, så ville virksomheden blive rentabel $\ll^{16}$.

Forudsætningen for, at denne proces fungerer, er imidlertid stigende afsætningsmuligheder. Sålænge den kapitalistiske $\varnothing$ konomi befinder sig i en boomperiode med hurtig ekspanderende afsætningsmarked, kan også produktionspotenserne udvides; ja enkeltkapitalerne må endog på grund af den omkostningsgunstige masseproduktion, der gennem konkurrencen bliver påtvunget alle enkeltkapitalisterne - for såvidt som produktionsprocessen og markedet tillader dette (her spiller brugsværdisiden af produktet ind) - fixerer stigende kapitalmasser i produktionsprocessen. Dette skete også i rationaliseringsbølgen i Tyskland mellem 1926 og 1928. Uafhængig af deres kapacitetsudnyttelsesomkostninger forårsager fixerede kapitalmasser reparationsomkostninger, renholdelses- og vedligeholdelsesomkostninger; også kreditter, der i reglen er blevet stiftet ved anskaffelsen af fixkapitaler, der rummer produktionsmidler, må forrentes og tilbagebetales uaf-

14. Som det kan læses hos A. Sohn-Rethel, Ökonomie und Klassenstruktur des deutschen Faschismus, Frankfurt 1973, s. 41.

15. E. Schmalenbach, cit. hos A. Sohn-Rethel, op.cit., s. 41.

16. Ibid s. 43. 
hængig af afsætningssituationen. Kostprisen på det enkelte produkt varierer på grund af fixomkostningsandelen ikke med variationen i udbredelsesmængden; med stigende fixomkostningsandel falder den således kun ubetydeligt ved en tilbagegang i den salgbare produktion eller den kan endog stige ${ }^{17}$. Et prisfald i krisen, der kunne have den funktion atter at rense værdidimensionen, rammer kapitalerne så meget des hårdere, jo højere den fixkapitalandel er, som forårsager »fixomkostninger«. Men mere endnu: Uelasticiteten på prisreaktioner har sit modstykke i uelasticiteten overfor den nødvendige tilpasning til ændrede afsætningsbetingelser. Ved høj fixkapitalandel er en skridtvis tilpasning af produktionsoutputtet ikke længere muligt. Hvis det for den givne enkeltkapital er tydeligt, at produktionsoutputtet ikke længere kan forhøjes, så vil den - for at undgå fixomkostningsbelastning - ved en bestemt kapacitetsudnyttelsesgrad snarere lade det samlet anlæg ligge stille end producere med underudnyttelse af kapaciteten. Men derved bliver krisen uddybet over al måde: produktionsindskrænkningerne er kraftigere end de egentlig behøvede at være ud fra afsætningssituationen. Det får igen konsekvenser for efterspørgselsforholdene (først og fremmest i afdeling I). Også opsvinget fra krisen bliver derved vanskeliggjort. For nye anlæg bliver først opført eller gamle braklagte anlæg tages i anvendelse igen, når realiseringschancerne er tilstrækkelige store for at afsætte de producerede varer - forudsat, at devaloriseringen og løntrykket under krisen er sat så vidt igennem, at profitabel produktion overhovedet er muligt. Her viser det sig, at i krisen må der tages hensyn til produktionens betingelser, dvs. produktion af profit og kapitalcirkulationen til realiseringen af den producerede værdi og profit. Den første betingelse kræver »udrenselse « af kapitalstrukturen gennem devalorisering (konkurs, prisfald osv.) såvel som disciplinering af lønarbejderne (løntryk, stigning i arbejdstid og arbejdsintensitet). Den anden betingelse nødvendigg $\varnothing \mathrm{r}$ et for varens produktionsbetingelser modsvarende realiseringsfelt, der må være så meget desto større, jo større mindsteafsætningsmængden er for rentabel drift af et anlæg. Dermed er vi imidlertid allerede ved den anden sammenhæng, der forekommer os væsentlig til forklaring af krisens dybde og varighed.

For det andet: det næsten fuldstændige sammenbrud af verdensmarkedet, som fandt sted på denne tid, er ligeledes af vigtighed for krisens vægt og varighed. Ikke blot - med kreditkrisens udbrud, der overfladisk dateret indgik i historien som »sorte fredag « på New Yorker børsen i september 1929 -

17. Det kan tydeliggøres med et eksempel: Hvis en produktion på 100 stk. giver omkostninger til et beløb af 10000 pengeenheder, så vil kostprisen være 100 pengeenheder pr. stk. Men af disse omkostninger på 10000 pengeenheder kan de 5000 være uafhængige af produktionsmængden. Ved en tilbagegang til 60 stk. bliver ifølge vores antagelse de variable omkostninger 3000 (nemlig 60\% af 5000), de fixe omkostninger 5000. Totalomkostningerne ved produktionen af 60 stk. er altså 8000 pengeenheder. Kostprisen pr. stk. bliver ved den formindskede produktion altså ikke længere 100, men 133,3 pengeenheder. Dette er et kendt fænomen i driftsøkonomien. Jvf. eksempelvis E. Heinen, Betriebswirtschaftliche Kostenlehre Bd. 1, Grundlagen, Wiesbaden 1959, s. $280 \mathrm{ff}$. 
udgjorde den udenlandske kapital i Tyskland, fremfor alt den amerikanske, et kriseforstærkende element og i 1931 efter sammenbruddet af Danatbanken blev den lynhurtig gjort flydende og trukket tilbage; men med sammenbruddet af valutasystemet (ophævelsen af Pund-sterlingens konvertibilitet og overgangen til deviseregulering i Tyskland) blev også realiseringschancerne for varer $\mathrm{i}$ andre lande næsten umuliggjort. For som følge af den almene krise aftog afsætningsmulighederne hurtigt, hvilket igen var anledning til protektionistiske foranstaltninger. Det nationalt begrænsede marked viste sig imidlertid i krisen at være for lille til at kunne beskæftige den kapacitet, der var anlagt ud fra et større realiseringsfelt.

Dertil kommer for det tredie noget mere til. På trods af den økonomiske verdenskrise havde en hidtil ukendt vægt $\mathrm{i}$ kapitalismens historie, så kunne den ikke reducere de beskaftigede arbejderes lønninger uden tidsforsinkelse i Tyskland (det ser anderledes ud i USA). ${ }^{18}$ Trykket fra den hurtigt voksende industrielle reserverarme begyndte kun langsomt at virke, især da arbejderklassen endnu ikke var så demoraliseret, at der ikke blev ydet hård modstand mod trykket fra kapitalen. ${ }^{19}$ Således gik det til, at den tarifmæssige timeløn for de beskæftigede arbejdere i Tyskland indtil 1930 stiger og først i det tredje kriseår falder, mens leveomkostningerne allerede i året 1930 falder radikalt p.gr.a. det stærke prisfald. ${ }^{20}$ Efter Kroll falder derfor også gevinstopnåelsen allerede fra 1928 og kapitalrentabiliteten falder. (Jvf. også figur 1). Ud fra denne måske overraskende sammenstilling må man dog på ingen måde slutte, at arbejdernes situation var forbedret, mens kapitalisternes var forværret. Arbejdsløsheden, der allerede i 1928 er meget høj med næsten 1,4 mio., stiger siden begyndelsen af den akutte krise med tiltagende hurtighed indtil det officielt højeste tal på mere end 6 mio. i året 1933. ${ }^{21}$. Således formindskes også allerede fra 1929 den samlede arbejdsindkomst. Udgjorde den endnu i 1928 i Tyskland 42,6 mia. RM, så udgør den i 1932 med 25,7 mia. RM nu knapt 60\% af oprindelsesværdien ${ }^{22}$.

18. Jvf. dertil G. Kroll op.cit. s. 74.

19. At lønningerne i forhold til kapitalens akkumulationsbeov var for høje og profitten for lav, men lønningerne stiger på ingen måde absolut - som kurven for »W « i figur 1 kunne lade formode, viser enhver konfrontation af løn- og profitudviklingen. Jvf. Statistisches Handbuch op.cit., s. 463 (prisindex), s. 472 (tarifløn), s. 484 (arbejdsløshed); også E. Hennig, Thesen zur deutschen Sozial- und Wirtschaftsgeschichte 1933 bis 1938, Frankfurt 1973, s. 53, passim.

20. Jvf. Statistisches Handbuch op.cit., s. 463/472.

21. Jvf. Statistisches Handbuch op.cit., s. 484f.

22. Jvf. oplysninger hos G. Kroll op.cit., s. 108. Hele den elendighed, som arbejderklassen i disse år måtte lide - elendigheden, som ganske vist skyldtes »de økonomiske forholds stumme tvang «, ikke den fascistiske terror til opretholdelsen af kapitalherredømmet med brutale midler - kommer ikke til udtryk i disse data. Tallenes skinobjektivitet skjuler denne sammenhæng, der heller ikke i en økonomisk analyse er til at afsløre. Vi er klar over begrænsningerne ved en sådan analyse, men mener dog, at det er nødvendigt at fremstille globale - og derfor abstrahere fra individuel og kollektiv erfaret elendighed - tendenser for at forstå den historiske sammenhæng mellem den verdensøkonomiske krise, dens politiske løsningsformer og den vesttyske kapitalakkumulation efter den anden verdenskrig. 
De tendenser, som her kun er skitseret og som er begrænset til Tyskland, kan vi forfølge ved hjælp af figur 1. I den bliver det tydeligt, at fra 1929 tiltog kapitalstocken indenfor håndværk og industri ikke længere og i årene fra 1930 til 1933 aftog den endog (jvf. $g_{k}$ ). Dette er et tegn på, at selv reinvesteringer ikke længere bliver foretaget i tilstrækkeligt omfang. Og øjensynlig formindskedes den kapital, der var anlagt i produktionsmidler, ikke i tilstrækkelig grad til at forhøje valoriseringsgraden for den endnu fungerende kapital. Lønkvotens (w) stigning, der kan uddrages af figur 1, kan - som det allerede er fremført - ikke føres tilbage til en vækst i arbejdsindkomsterne, men til et absolut fald i nettoproduktet (Y) og til den negative profit, der er opstået som følge af kapitaltab. Alligevel måtte reallønningerne for de beskaftigede arbejdere ikke været faldet tilstrækkeligt til at skaffe kapitalen en profitstimulans. Derfor faldt da også kapitalrentabiliteten uhørt. Kapitalismen blev til en »kapitalisme med omvendt profit-fortegn $\ll^{23}$.

For imidlertid ikke at drage falske og ensidige slutninger af denne fremstilling, må det betones, at for det første var kapitalrentabilitetens nedgang $\mathrm{i}$ USA langt større end i Tyskland (og frembragte dog ikke nogen form for fascistisk borgerligt herredømme) og at for det andet har kapitalrentabilitetens fald været fuldstændig uens - hvis man henholder sig til enkelte brancher og fremfor alt til kapitalens størrelse (monopolisering!). Krisen formindskede ganske vist kapitalens $\emptyset$ konomiske magt, men det var på ingen måde ensbetydende med en magtgevinst til arbejderklassen og dens organisationer. Under krisens forløb viste det sig mere og mere, at kapitalen behøvede en politisk renselseskrise, når den ikke var i stand til ved egne kræfter at komme ud af depressionen. ${ }^{23 a}$ Dette lovede nazipartiet at tilbyde som hestekur. Selvom de økonomiske forudsætninger for fascismen hermed er karakteriseret, så er den politiske gennemførelse af »magtovertagelsen « dermed på ingen måde tilstrækkeligt bestemt. Endelig må man tænke over den kendsgerning, at krisen var langt værre i USA end i Tyskland og dér kunne en fascistisk bevægelse ikke »overtage magten«. Vi henviser kun til det for at påpege, at på dette sted skulle de politiske, sociale, ideologiske processer inddrages for virkeligt at begribe fænomenet den tyske fascisme ${ }^{24}$. Svarende til vores

23. Således A. Sohn-Rethel, op.cit. s. 120. Vores figur 1 viser at denne sætning kan tages for sin fulde ordlyd.

23a. På krisens funktion som økonomisk »renselsesmiddel« byggede endnu i 1929 eksempelvis Thyssen: »Jeg har brug for denne krise nu. Den frembyder den eneste mulighed for med et slag at regulere lønspørgsmålet og reparationerne.« cit. hos Ch. P. Kindleberger op.cit. s. 183.

24. Vi kan ikke i denne sammenhæng gå udførligt ind på det særlige forhold mellem politik og $\emptyset$ konomi, hvordan det fremkaldte den engang igangsatte fascistiske løsning på krisen, eller på forholdet mellem bourgeoisiet og det fascistiske parti. Jvf. dertil A. Sohn-Rethel op.cit. også B. Blanke, Thesen zur Faschismus-Diskussion, i: Sozialistische Politik, nr. 3 (1969); N. Kadritzke, Fascismus als gesellschaftliche Realität und als unrealistischer Kampfbegriff, i: Probleme des Klassenkampfs, nr. 8/9 (1973) s. 129ff; vigtig er også diskussionen i Argument nr. 32 (1965); 41 (1966); 47 (1968) mellem Mason og Gichon og andre. 
begrænsede målsætning med denne analyse giver vi afkald på en udførlig fremstilling og går over til at undersøge det fascistiske » 1000 års « betydning for den vesttyske kapitals senere udviklingsproces.

\subsection{Fascismen i Tyskland}

Depressionen efter krisen kan overvindes, hvis merværdiraten forh $\varnothing$ jes gennem lønnedsættelse, forlængelse af arbejdstiden, intensivering af arbejdet, og hvis stigningen i arbejdets produktivkraft ikke tilintetgøres af en hermed sammenhængende stigning i kapitalintensiteten, der har negative konsekvenser for udviklingen af kapitalrentabiliteten, og ikke mindst hvis renten sænkes i forhold til den industrielle profit. Imidlertid måtte forbedringen af realiseringsbetingelserne for den producerende varekapital komme fra det indenlandske og det udenlandske marked, hvorved efterspørgselsudviklingen væsentligt bestemmes af kapitalernes indbyrdes efterspørgsel, dvs. af deres profitudsigter. Disse forudsætninger for et fornyet opsving for den kapitalistiske produktionsmåde kunne imidlertid ikke længere tilvejebringes på den »traditionelle måde « for kapitalistisk kriseovervindelse under forløbet af den økonomiske verdenskrise - som vi senere kan konstatere. Ved dette erkendelsespunkt begyndte de borgerlige teorier i 30'erne, da de drog den slutning, at uden statslige indgreb ville investeringsniveauet være for lavt til at sikre den fulde beskæftigelse for arbejderbefolkningen. Som den første faktor, der var ansvarlig for det utilstrækkelige investeringsniveau, udpegede stagnationsteoretikeren Alvin Hansen den utilstrækkelige befolkningstilvækst i sammenligning med det 19. årh. Dermed var en hurtig udvidelse af den effektive efterspørgsel begrænset. Som anden faktor udpegede han det tekniske fremskridt, der have mistet sin styrke. For det tredje var det ikke længere muligt territorialt at udvide den kapitalistiske produktionsmåde, så også den vækstimpuls, der udgik fra »new frontier«, var aftaget. Disse faktorer skulle bekræfte Keynes udsagn om, at »kapitalens grænseproduktivitet «, dvs. profitabiliteten var aftaget sammenlignet med det 19. årh., og kun ved hjælp af statslige indgreb kunne de stagnative tendenser virksomt modgås. ${ }^{24 a}$

Således var den borgerlige teori som videnskabelig refleks af de praktiske indvundne erfaringer i og efter krisen i det mindste implicit bevidst om, at politiske interventioner gennem staten var nødvendige i kapitalreproduktionen for at hæve »kapitalens grænseproduktivitet« til et »tilfredsstillende «

24a. Jvf. den korte, men præcise diskussion hos Eric Roll, A History of Economic Thought, London 1973 ligesom C. Napoleoni, Grundzüge der modernen ökonomischen Theorien, Frankfurt 1968. 
stillende « niveau. Med andre ord: Kapitalens profitrate kunne ikke længere 'genoprettes alene gennem de renselsesprocesser, der udspiller sig i krisen. Statslige aktioner var tværtimod nu nødvendige for at hæve profitraten.

Vi har ikke her til hensigt udførligt at fremstille og kritisere stagnationstesen. For os drejer det sig kun om at vise, at under den $\varnothing$ konomiske verdenskrise havde de betingelser udviklet sig, der umuliggjorde et nyt opsving uden politiske indgreb fra staten. Den »laisser faire « politik, som den $\varnothing$ konomiske teori i vide kredse postulerede indtil krisen, selv om den aldrig blev virkeliggjort, havde således vist sig som uanvendelig i og med at kapitalismen havde vist sig som uduelig til af egen kraft at overvinde depressionen.

Således begyndte statsinterventionismen at spille en større rolle i alle kapitalistiske lande; i Tyskland blev denne proces fuldbyrdet på den mest konsekvente måde - i kapitalistisk forstand -, eftersom her alle de institutioner i det borgerlige-demokratiske samfund, der stod i vejen for en hurtig forhøjelse af kapitalens profitabilitet og en fremskyndelse af akkumulationsprocessen, blev tilintetgjort: for at hæve udbytningsraten af arbejderklassen blev arbejderklassens politiske og fagforeningsmæssige organisationer brutalt $\varnothing$ delagt og i stedet for blev arbejderklassen gennem statslig or ganisering i den Tyske Arbejderfront så disciplineret, at arbejdstiden kunne forlænges, at arbejdet kunne intensiveres, at arbejdskraftens mobilitet kunne indskrænkes, og at lønningerne kunne begrænses.

En sådan svækkelse af den økonomiske og politiske magt hos arbejderbevægelsens organisationer tjente også til at fjerne det parlamentariske system, hvormed tillige modsigelserne indenfor kapitalistklassen, der havde kunnet nedsætte de statsinterventionistiske foranstaltningers virkning, blev hæmmet i deres politiske artikulationsmulighed og den borgerlige klasse blev forenet $\mathrm{i}$ det mindste på den politiske overflade - uden dermed at ophæve konkurrencen mellem kapitalerne ${ }^{25}$. For at udelukke den tyske kapital fra verdensmarkedskonkurrencen, blev der ført en autarkisk politik indadtil og udadtil expansion, der kun er bagsiden af autarkipolitikken ${ }^{26}$. Den magtudfoldelse, der i den forbindelse var nødvendig, betød forceret oprustning, militarisering af hele samfundet. Dermed havde man samtidigt formindsket det problem, der melder sig ved ethvert nyt opsving, nemlig at realisere de producerede varemasser under

25. Dette fremhæver E. Varga op.cit. s. 110: - nu engang gør de indre modsigelser mellem de enkelte kategorier af kapitalister sig gældende. Hoover har foreslået store investeringer i jernbaner, men samtidig også udbygning af kanalsystemet og vidt udbredt anlæg af veje. Jernbanekapitalen protesterer: Du kræver af os, at vi skal anbringe en milliard dollar i vores jernbaner, men samtidig organiserer du konkurrencen fra skibsfarten og automobilerne mod os! Hvordan kan vi under sådanne omstændigheder anbringe ny kapital i jernbaner, vi vil jo kun have tab! Varga anfører på det angivne sted endnu flere sådanne modsigelser mellem kapitalfraktionerne.

26. F. Pollock, Die gegenwärtige Lage des Kapitalismus und die Aussichten einer planwirtschaftlichen Neuordnung, i: Zeitschrift für Sozialforschung, Jahrg. 1. 1932. 
profitable betingelser. For den oprustning, der blev iværksat fra 1934, betød for kapitalen en stadig udvidelse af afsætningsområdet.

Vor tese om kapitalens udvikling under fascismen lyder: 1. Gennem de fremtvungne lave lønninger, den lange arbejdstid og forringelse af de lønafhængiges levestandard blev mervardiraten absolut forhøjet. Dermed blev forudsætningerne for profitproduktion afgørende forbedret, mens samtidig realiseringen af de producerede og potentielle producerbare værdi- og merværdimasser var sikret gennem udelukkelsen af den udenlandske konkurrence fra hjemmemarkedet og gennem udviklingen af den statslige efterspørgsel i form af beskæftigelses- og rustningsprogrammer. På dette grundlag kunne værdiproduktionen forøges gennem udvidelsen af arbejdstiden og intensivering af arbejdet hos de beskæftigede arbejdere og gennem indlemmelse af hidtidige ubeskæftigede arbejdere i den kapitalistiske produktionsproces. 2. Gennem den absolutte formindskelse af værdien af varen arbejdskraft (og udelukkelsen fra verdensmarkedskonkurrencen) var kapitalen foreløbigt ikke tvunget til væsentligt at hæve arbejdets produktivkraft. Samtidig blev reproduktionsbetingelserne for den samfundsmæssige totalkapital afgørende ændret gennem den statslige efterspørgsel: de forhåndenværende produktionsressourcer i afdeling I måtte for en større del holdes fri til produktion af rustningsgoder, mens reallønningernes stagnation modsvarede en stagnation af konsumgodeindustrien. Den sidstnævntes produktivkraft blev praktisk taget ikke forøget, for den havde jo betydet yderligere efterspørgsel efter produktionsmidler fra afdeling IIs side i forhold til afdeling I (hvor disse bliver produceret). Den absolutte nedgang i arbejdslønnen og dermed i massernes konsumkraft kompleterede og modsvarede den accelerede profitproduktion og realiseringen af de producerede værdier gennem den statslige efterspørgsel efter rustningsgoder. De to teser skal nu udvikles.

Arbejderklassens situation er først og fremmest bestemt af arbejdsløshedens omfang. Den har nemlig i kapitalakkumulationens cykliske forløb den funktion at sænke prisen på varen arbejdskraft. Massearbejdsløsheden under den $\emptyset$ konomiske verdenskrise har netop haft denne effekt: Hvis vi f.eks. sætter den tarifmæssige timeløn for faglærte arbejdere i 1928 til 100, så falder denne løn indtil 1933 til 81,9. Dette er der intet særligt ved sammenlignet med lignende udvikling i andre kapitalistiske lande under den $\emptyset$ konomiske verdenskrise. Det særlige ved den tyske udvikling under fascismen viser sig først, når vi undersøger om lønningerne igen steg efter overvindelsen af den økonomiske verdenskrise $^{27}$ ved det begyndende opsving: Selv i de år, hvor arbejdsløsheden i praksis var overvundet gennem den udviklede statslige efterspørgsel efter rustningsgoder og gennem andre beskæftigelssprogrammer, skete der ingen nævneværdige lønstigninger; lønningerne blev tværtimod lovmæssigt begrænset

27. Jvf. dertil materiale hos G. Kroll, op.cit. 
(lønstop i 1933), arbejdskraftens mobilitet blev indskrænket ${ }^{28}$. Således forblev lønningerne for alle arbejderkategorier under det niveau, som de havde nået før den $\varnothing$ konomiske verdenskrise. Ved en sammenligning af den reale bruttotimefortjeneste viser det sig, at kun i årene 1939 og 1941 blev niveauet for 1933 nået. I alle de andre år forblev lønningerne under det niveau, der var opnået før den fascistiske magtovertagelse. At dette tydeligvis havde følger for arbejdskraftens vardi, altså for værdien af den gennemsnitlige konsumfond, viser følgende oversigt over per-capita-forbrug af nogle livsvigtige varer: I tidsrummet fra 1930 til 1938 - altså fra krisens laveste punkt til den fascistiske konjunkturs blomstring - stiger per-capitaforbrug af kød omtrent $12 \%$; forbruget af fjerkræ går næsten $12 \%$ tilbage; forbruget af æg falder med 14\% og forbruget af drikkemælk stagnerer; forbruget af forskellige spiselige fedstoffer går alt i alt tilbage, dog stiger forbruget af smør omkring 9\%; kartoffelforbruget stiger i disse 8 år næsten 5\%, mens forbruget af frugt og grøntsager kraftigt reduceres ${ }^{29}$. Med denne »stigningsrate « blev end ikke niveauet for 1928 nået, der atter kun lå ubetydeligt over 1913 niveauet. En sådan stagnation af konsumtionsniveauet måtte fremtvinges ad statslig vej ${ }^{30}$.

Samtidig aftog arbejdsløsheden kontinuerligt efter den fascistiske magtovertagelse. Efter højdepunktet i januar/februar 1933 med over 6 mio. arbejdsløse går tallene tilbage. I april 1937 kommer man for første gang siden 1927 under milliongrænsen. Også beskæftigelsen tiltager regelmæssigt, selvom en del af de arbejdsløse ikke bliver indlemmet i produktionsprocessen som følge af oprustningen (opbygning af »Wehrmacht «), men forsvinder $i »$ Wehrmacht « eller andre militære og paramilitære organisationer. (En anden del - klassebevidste, politiske aktive proletarer bliver kastet i fængsler og koncentrationslejre).

Denne udvikling står i modsætning til den i USA, hvor lønningerne steg meget hurtigere trods en langt langsommere udryddelse af arbejdsløsheden: Sætter man 1929 lig med 100, så nåede reallønningerne i Tyskland i 1937 98, mens de i USA steg til 132. Samtidig blev i Tyskland den ugentlige arbejdstid udvidet: Den var i 1938 for mænd over 50 timer, for kvinder næsten 48, og dette skønt 48-timer arbejdsugen allerede var blevet tilkæmpet efter den første verdenskrig. Denne udvidelse af arbejdstiden og af beskaftigelsen af produk-

28. Jvf. dertil også, ligesom i det følgende også problemet om arbejdskraftens værdisænkning under fascismen, E. Mandel, Der Spätkapitalismus, Frankfurt 1972 s. 152.

29. Statistisches Handbuch von Deutschland op.cit., s. 488; egne beregninger.

30. Sohn-Rethel taler i denne sammenhæng om »absolut merværdiproduktion«. Det forekommer os at være problematisk, da han for det første mekanisk stiller absolut og relativ merværdiproduktion over for hinanden og for det andet ikke tager hensyn til, at produktivkraftsstigningerne (ved konstant arbejdstid) legemligg $\varnothing \mathrm{r}$ sig i et forøget brugsværdikvantum, uden at - ceteris paribus - værdimassen behøver at forøges; massernes konsumtionskraft kan - ved tilsvarende prisfald - altså forøges, uden at lønnen behøver at forøges. De ændrede metoder for profitproduktionen kan derfor kun analyseres i sammenhæng med de specifikke betingelser for akkumulationen. 
tive arbejdere havde den allerede ovenfor beskrevet effekt, at de værdi- og merværdiskabende potenser alt i alt blev udvidet.

Som følge af værdiformindskelsen af arbejdskraften blev tydeligvis også forholdet mellem merværdimassen og variabel kapital (»udbytningsgraden «) ændret til fordel for kapitalen. Vi kan her kun illustrere forandringen af udbytningsraten ved forandringen af lønkvoten og af forholdet mellem kapital- og arbejdsindkomst. Ifølge det faldt lønkvoten (for hele produktionen) - målt som lønandel af nationalindkomsten - fra 64\% i 1932 under fascismen til 57\% i 1938 (niveauet for 1932 blev i øvrigt først igen nået i 1963 - i Vesttyskland!). Derimod steg - ifølge A. Schweitzers beregninger ${ }^{31}$ - de store virksomheders gevinster fra 1932 til 1936 med 433\%. Man kommer til lignende resultater, hvis man sætter de af W. G. Hoffmann undersøgte tal for arbejds- og kapitalindkomster i de forarbejdende erhverv i forhold til hinanden; i den følgende tabel (s. 24) er tallene fra Weimar republikken og BRD taget med for at give et bedre overblik ${ }^{32}$.

Fascismens historiske funktion fremtræder ganske tydeligt i denne talrække. Den fik meget hurtigt og i vældig omfang bragt udbytningsraten af arbejderklassen (indiceret ved forholdet mellem kapitalindkomster og arbejdsindkomster) op på et niveau, der ligger mere end 300\% over niveauet i Weimar Republikken. Derigennem blev profitraten i den grad forhøjet, at kapitalakkumulationen tog et nyt opsving. Kapacitetsudnyttelsen steg hurtigt især p.gr.a. rustningskonjunkturen og opførelsen af ny kapacitet blev profitabelt p.gr.a. de statsligt fastsatte lønninger, det lavt fastholdte konsumtionsniveeau, og det hurtigt stigende statsforbrug. Den organiserede arbejderbevægelse var tilintetgjort og ethvert forsøg på at modsætte sig det fascistiske herredømme endte i KZ. Derfor kan Pritzkoleit skrive: »I et ord: Industrien gik det godt. Arbejdsgiverne var igen herre i sit eget hus. Mellem virksomhedsledelsen og de underordnede kunne hverken fagforeningen eller virksomhedsråd træde ind ... Personalet var forpligtet til at være deres virksomhed tro, dvs. de var bundet til deres virksomhed og måtte tage til takke med den principielt stabile løn, der blev dem tilbudt... $\ll^{33}$

Den lavt fastholdte arbejdsløn, stagnationen af konsumtionsniveauet for de lønafhængige og udelukkelsen af verdensmarkedskonkurrencen fra det tyske marked skabte muligheder for den tyske kapital at producere til en højere merværdirate, uden at arbejdsproduktiviteten (Y/L) i almindelighed blev væsentligt forhøjet (med undtagelse af bestemte områder inden for sværindustrien og investeringsvareindustrien). Afdeling I's ressourcer blev gennem den statslige rustningsefterspørgsel omdirigeret til rustningsproduktionen og dermed blev den brakliggende kapacitet helt udnyttet, mens den tyske kapitals kapitalstock alt $i$ alt ikke blev udvidet væsentligt.

31. Arthur Schweitzer, Labour in Organized Capitalism, Schweizerische Zeitschrift für Volkswirtschaft und Statistik, 1959, s. 497.

32. Jvf. også Mandel op.cit.

33. K. Pritzkoleit, Gott erhält die Mächtigen, Düsseldorf 1963, s. 30. 
Tabel 1:

Udvikling i kapitalstock, arbejds- og kapitalindkomster 1925-1959.

\begin{tabular}{|c|c|c|c|c|c|}
\hline & $\AA \mathrm{r}$ & $\begin{array}{l}\text { Kapital- } \\
\text { stock } \\
\text { Mia. RM } \\
2\end{array}$ & $\begin{array}{l}\text { Arbejds- } \\
\text { indkomster } \\
\text { Mia. RM } \\
3\end{array}$ & $\begin{array}{c}\text { Kapital- } \\
\text { indkomster } \\
\text { Mia. RM } \\
4\end{array}$ & $\begin{array}{c}\text { Forholdet } \\
\text { mellem } 4 \\
\text { og } 3 \text { i \% } \\
5\end{array}$ \\
\hline \multirow{10}{*}{ Weimar } & 1925 & 114,4 & 31,2 & 2,6 & 8,4 \\
\hline & 1926 & 112,2 & 30,1 & 2,3 & 7,7 \\
\hline & 1927 & 118,2 & 36,6 & 5,9 & 16,1 \\
\hline & 1928 & 128,3 & 40,8 & 5,3 & 13,0 \\
\hline & 1929 & 131,4 & 42,9 & 5,5 & 12,8 \\
\hline & 1930 & 127,4 & 39,2 & 3,0 & 7,7 \\
\hline & 1931 & 115,1 & 31,2 & 0,5 & 1,6 \\
\hline & 1932 & 99,3 & 23,4 & $-9,0$ & - \\
\hline & 1933 & 95,5 & 23,7 & $-2,0$ & - \\
\hline & 1934 & 99,6 & 28,0 & 2,1 & 7,5 \\
\hline & 1935 & 102,8 & 30,5 & 7,1 & 23,2 \\
\hline \multirow[t]{7}{*}{ Fascisme } & 1936 & 105,6 & 33,3 & 7,6 & 23,6 \\
\hline & 1937 & 114,9 & 36,6 & 13,5 & 37,2 \\
\hline & 1938 & 123,3 & 39,5 & 17,1 & 43,4 \\
\hline & 1950 & 147,4 & 38,9 & 15,5 & 40,0 \\
\hline & 1951 & 182,8 & 46,7 & 20,5 & 43,9 \\
\hline & 1952 & 207,6 & 51,7 & 23,6 & 45,5 \\
\hline & 1953 & 213,7 & 56,9 & 24,9 & 44,0 \\
\hline \multirow[t]{6}{*}{ BRD } & 1954 & 225,4 & 62,3 & 30,3 & 48,7 \\
\hline & 1955 & 252,2 & 70,7 & 33,0 & 46,6 \\
\hline & 1956 & 278,5 & 79,1 & 34,4 & 43,2 \\
\hline & 1957 & 306,9 & 85,8 & 37,5 & 43,0 \\
\hline & 1958 & 329,7 & 92,0 & 37,1 & 40,5 \\
\hline & 1959 & 354,5 & 98,4 & 46,6 & 47,5 \\
\hline
\end{tabular}

Kilde:

W. G. Hoffmann, Das Wachstum der deutschen Wirtschaft seit der Mitte des 19. Jahrhunderts, Berlin-Heidelberg-New York 1965, s. 507 ff og 256; (egne beregninger).

Af tabel 1 fremgår det, at kapitalstockens niveau på intet tidspunkt under fascismen (1933-1938) når kapitalstockens højde i 1928; kapitalstockens ringe tilvækstrate (her: industri og håndværk) fremgår tydeligt af figur 1, hvilket 
også bliver bekræftet af Bettelheim ${ }^{34}$, der går udfra, at under fascismen tilfaldt kun $30 \%$ af investeringerne »de produktive private investeringer «. Kapitalproduktiviteten $(\mathrm{Y} / \mathrm{K})$ blev forhøjet uforholdsmæssigt ved den stigende udnyttelse af den forhåndenværende kapitalstock og ved indlemmelsen af brakliggende arbejdskræfter i produktionsprocessen, forlængelsen af arbejdstiden etc. På den anden side måtte ikke blot det akutte råstofproblem, der var opstået med udelukkelsen fra verdensmarkedet, løses, men den efterspørgsel, der hidtidig er udgået fra verdensmarkedet, måtte også erstattes og »finansieres « indenlandsk gennem »en statslig efterspørgsel «. En sådan efterspørgsel kunne åbenbart ikke komme fra kapitalen ved den foreløbig givne valoriseringssituation. Til forskel fra USA og Storbritannien kunne Tyskland ikke gribe tilbage til traditionelle råstofs- og afsætningsmarkeder, især da den akkumulation, der igen kom igang i disse lande i 1932/33, væsentligt blev båret af udadtil afskærmede indenlandske konjunkturer. Den fascistiske stat måtte derfor garantere realiseringen af værdiproduktet ved rustningsefterspørgslen, der blev finansieret ved den statslige tvangsfiktion (Mefo-veksel), der på ingen måde modsvarede en reel modværdi: Det var i sidste instans veksler på de kommende erobrede råstofs- og afsatningsområder. ${ }^{35}$

Den terroristisk forhøjede udbytningsrate og den absolutte fastholdelse af de lave lønninger svarede på denne måde til rustningsproduktionens behov, og på den anden side blev modifikationen af den indre sammenhæn mellem afdelingerne i den samfundsmæssige reproduktionsproces muliggjort gennem udelukkelsen af verdensmarkedskonkurrencen (gennem garantien for disse betingelser lå også her interesseidentiteten mellem kapitalen og den fascistiske stat); på samme måde blev den militære ekspansion derfor ikke blot bevidst tilstræbt af den fascistiske bevægelse med den engang iværksatte kriseløsning, men den blev også $\varnothing$ konomisk nødvendig forudsætning for »betalingen af deficits« ved hjælp af materiale-, kapacitets- og arbejdsreserver, der skulle erobres. Rustningsproduktionen skabte altså ikke blot den materielle forudsætning, men fremtvang i denne sammenhæng netop den militære expansion! Bourgeoisiets opposition mod Hitler måtte derfor - som Sohn-Rethel anskueligt beskriver - forblive virkningsløs, da det ikke længere selv havde noget ( $\varnothing$ konomisk) alternativ at tilbyde ${ }^{36}$.

Autarkipolitik, terroristisk forhøjelse af merværdiraten og imperialistisk expansion blev på denne måde fuldstændiggjort. Vi kan tydeliggøre vor tese om kapitalens udvikling under fascismen ved hjælp af figur 1:

34. Ch. Bettelheim, Die deutsche Wirtschaft unter dem Nationalsozialismus, München 1974, s. 249: »Alt i alt overstiger de områder, som vi har regnet til privatinvesteringer, først i 1938 niveauet for $1928 \ldots \ll$ Og: »I dette tidsrum fandt der heller ingen udvikling sted af produktivkræfter i egentlig forstand, ser man bort fra begrænsede sektorer inden for sværindustrien «. (s. 250). Aktieselskabernes nominalkapital faldt - ifølge Bettelheim - endog fra 22,26 mia. RM (1932) til 18,74 mia. RM (1938).

35. Ang. fremstillingen af finanseringsmekanismen for oprustningen jvf. Ch. Bettelheim, op.cit. og Sohn-Rethel, op.cit.

36. Vi henviser på dette sted til den i note 24 citerede litteratur! 
Figur 1:

Udvikling i kapitalproduktiviteten Y/K, lønkvoten w, væksten i kapitalstocken gK og i kapitalrentabiliteten pii årene 1925-1939 (industri og håndværk).

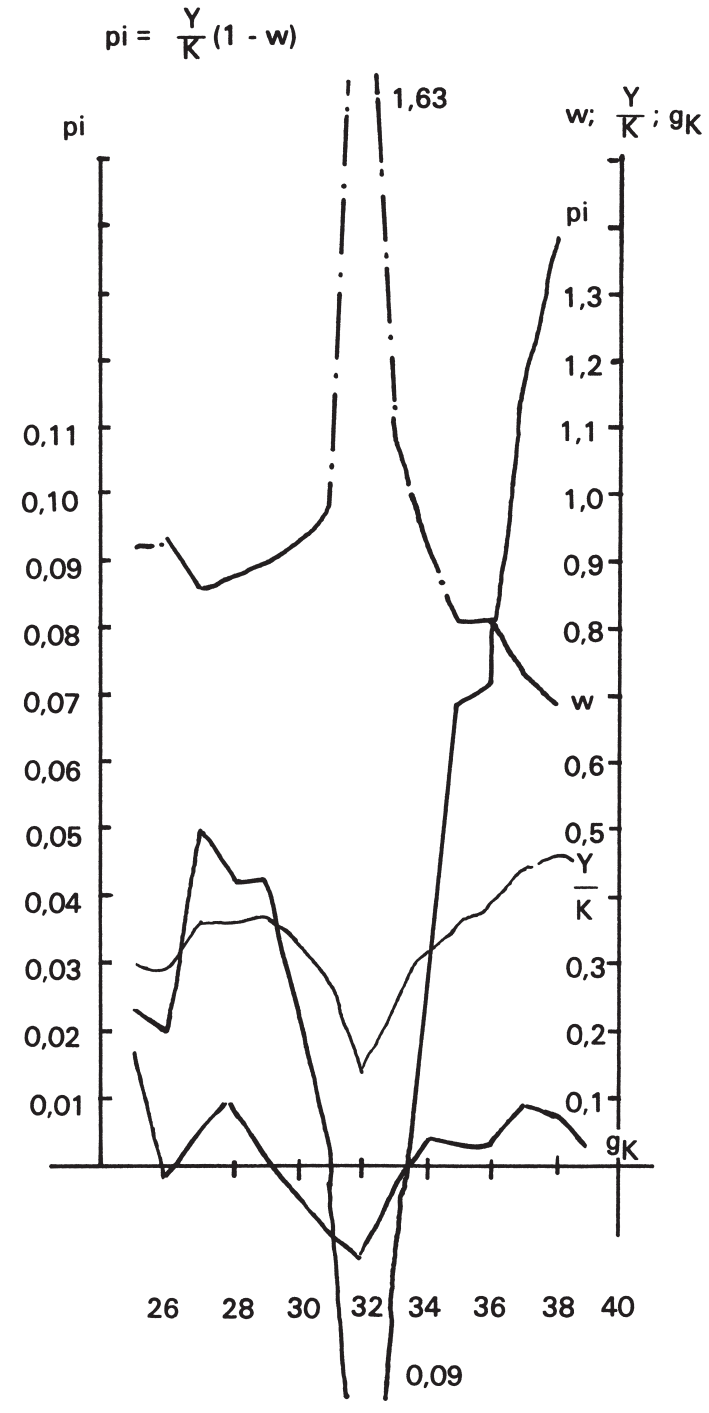

Kilde:

egne beregninger på basis af data fra W. G. Hoffmann: Das Wachstum der deutschen Wirtschaft seit Mitte des Neunzehnten Jahrhunderts, Berlin/Heidelberg/New York 1965. 
Mens lønkvoten w trykkes langt ned under niveauet for 1926-1930 (og i $\varnothing v$ rigt også langt ned under gennemsnitsniveauet fra 1850 til 1913) stiger nettoproduktet i forhold til den forhåndenværende kapitalstock (kapitalproduktivitet $\mathrm{Y} / \mathrm{K}$ ) uforholdsmæssigt hurtigt. Dette kan føres tilbage til den hurtige stigning i de værdi- og merværdidannende potenser, der fandt sted inden for dette tidsrum som følge af indlemmelsen af arbejderne i produktionsprocessen, forlængelsen af arbejdstiden og intensiveringen af arbejdet (forhøjelse af nettoproduktet $\mathrm{Y}$ ved stagnerende kapitalstock K). Udviklingen i kapitalrentabiliteten pi som det sammenfattede udtryk for kapitalens valoriseringssituation illustrerer iøjenfaldende fascismens funktion i Tyskland: Indenfor 6 år blev kapitalrentabiliteten pi skruet op fra $\div 9 \%$ til $c a .+14 \%$. Deraf slutter vi, at profitraten udviklede sig på lignende måde under fascismen.

\subsection{Anden verdenskrig og efterkrigstiden}

De terroristiske forhold under fascismen forværredes af den anden verdenskrigs virkninger: Arbejderklassens levefod blev yderligere forringet, den fascistiske terror mod enhver oppositionel bevægelse indenfor arbejderklassen og indenfor borgerskabet blev i den grad drevet i vejret, at den antog barbariske dimensioner, der aldrig før var set i menneskehedens historie. Det »overskud af irrationalitet «, der principielt er indlejret i den fascistiske bevægelse, fandt således sin forløsning.

For vor problemstilling er det vigtigt at besvare spørgsmålet om, hvilke konsekvenser krigen fik for kapitaludviklingen. I modsætning til den vidt udbredte opfattelse, at der i anden verdenskrig kun havde fundet destruktionsproceser sted, kan det påvises, at den anden verdenskrig for den tyske kapital gav anledning til massiv indførelse af ny teknologi i produktionsprocessen. Dette var ikke blot resultatet af de fordringer, som krigsførelsen stillede, men også af, at de arbejdskræfter, der var unddraget produktionsprocessen, måtte erstattes. Ganske vist kunne gabet delvis udfyldes af krigsfanger og andre udenlandske arbejdsslaver. Deres arbejdskraft var så billig for den tyske kapital, at teknologiske forandringer til besparelse på arbejdskraft, altså til forhøjelse af arbejdets produktivkraft, egentlig på mange områder blev overflødig p.gr. a. deres eksistens. Men ikke enhver forladt arbejdsplads kunne besættes med arbejdsslaver uden teknologiske forandringer. Derfor måtte der skaffes arbejdspladser, hvor uuddannede eller tillærte arbejdere, især kvinder, kunne indsættes. Det var altså nødvendigt at skaffe erstatning gennem stigning i produktivkraften ved de endnu beskæftigede og ikke ved fronten kæmpende arbejdere. Således blev der i løbet af anden verdenskrig indført masseproduktion ved samlebånd, masseserieproduktion med $\emptyset$ get standardisering og specialisering, - produktionsmetoder, der senere blev så vigtige i den første fase af kapitalakkumulationen i 
Vesttyskland. ${ }^{37}$ Udbredelsen af disse nye teknologiske metoder begunstigedes ved, at den indbyrdes konkurrence mellem kapitalerne var indskrænket som følge af krigsøkonomiens forholdsregler. På denne nye teknologiske og arbejdsorganisatoriske basis kunne således »andelen af de beskæftigede fagarbejdere sænkes betydelig. Kvinder og erhvervsfremmed arbejdskræfter kunne let tillæres, tvangsarbejdere indsættes $\aleph^{38}$. Koncentrationsprocessen blev fremskyndet, de producerede værdi- og profitmasser blev også under krigen forh $\varnothing$ jet betydeligt. Således gik det til, at den vesttyske kapital næsten indtil krigens afslutning kunne akkumulere og udvide sin samfundsmæssige magtposition, mens arbejderklassen, for så vidt den ikke producerede til krigen under extreme arbejdsbetingelser i produktionsprocessen, blødte i ordets egentlige betydning ved fronten eller i de fascistiske koncentrationslejrer.

Resultatet af den anden verdenskrig kan ikke kun ses under den økonomiske synsvinkel: den delvise kapitaltilintetgørelse som så at sige stikker tydeligst i $\varnothing j n e n e$ i form af ruiner. Vigtigere for historiens videre forløb er, at arbejderklassen gik svækket ud af krigen: dens organisationer var ødelagte, lederne var for største delen myrdet. Derfor blev det først rigtigt klart efter sejren over fascismen i 1945, hvilket omfang det nederlag havde, som den tyske arbejderklasse havde måttet tage imod i 1933 ved den nationalsocialistiske magtovertagelse.

Ganske vist gik også det vesteuropæiske og vesttyske bourgeoisi svækket ud af krigen både $\varnothing$ konomisk, politisk og ideologisk (sammenhængen mellem kapitalisme og fascisme var ikke til at overse) $)^{39}$. Uden hjælp udefra, nemlig af US-imperialismen, og også indefra, nemlig af spaltningen af arbejderklassen og dens nyopstående organisationer, havde det sikkert ikke været muligt at opretholde kapitalens herredømme. Der hvor US-imperialismens hjælp manglede, som i de østeuropæiske stater, blev kapitalens herredømme også meget hurtigt fjernet og erstattet med nye former for økonomisk ejendom og politisk herred $\varnothing m m e^{40}$. Men også i de vesteuropæiske lande truedes borgerskabets absolutte herredømme gennem erfaringerne fra den antifascistiske kamp, gennem erkendelsen af, at kapitalisme og fascisme hænger inderligt sammen, og gennem de dybe $\varnothing$ konomiske rystelser med følgende masseelendighed. Således fik radikaldemokratiske og tildels folkefrontbevægelser betydning i nogle vesteuropæiske lande (Italien, Frankrig).

37. Robert Katzenstein, Die Investitionen und ihre Bewegung im staatsmonopolistischen Kapitalismus, Berlin (DDR) 1967.

38. R. Katzenstein, op.cit., s. 130.

39. Dette bliver især tydeligt dokumenteret i CDUs Ahlener programmet fra 1947, hvori der explicit bliver henvist til sammenhængen mellem kapitalisme og fascisme. Naturligvis blev de konsekvenser, der havde måttet drages af denne erkendelse aldrig politisk virulent.

40. Det er ikke her muligt at gå ind på udviklingen i de fra fascismen befriede øst- og sydøsteuropæiske lande, der udviklede overgangsformer fra kapitalisme til socialisme. I deres selvforståelse definerede de sig som folkedemokratier i modsætning til det borgerlige demokrati, der havde desavoueret sig gennem fascismen. 
Fordi modsætningen til Sovjetunionen meget snart blev skærpet (»den kolde krigs « begyndelse i 1946), fik den økonomiske og politiske stabilisering af Vesteuropa imidlertid en særlig betydning, idet den skulle oprette »anti-kommunismens hellige alliance «. Med deres »European Recovery Program « (Marshall-planen) fors øgte USA således fra 1947 at videregive $\varnothing$ konomiske impulser for først og fremmest at skabe det $\varnothing$ konomiske grundlag for en borgerlig politik. Fra april 1948 til februar 1952 pumpede USA omkring 13 mia. dollar ud til Vesteuropa.

Den politiske restauration af den borgerlige klasse i Vesttyskland gik forud for den $\varnothing$ konomiske, den skete ikke uden støtte fra de kapitalistiske sejrsmagter (fremfor alt USA). US-besættelsesmagten så suverænt bort fra socaliseringsstemmer fra landsdagene og folkeafstemninger (Hessen og Nordrhein-Westfalen), og opbyggelsen af demokratiske bevægelser blev om ikke forhindret, så dog hæmmet. Fagforeninger blev opbygget fra oven og ikke gennem initiativ fra neden. »Ikke præjudicerings «-politikken af en tysk ordning, som det stadig hed, gik de facto ud på præjudicering af den samlede videre udvikling, i betydningen: rekonstruktion af den vesttyske kapita ${ }^{41}$. Særligt tydeligt bliver dette i tilfældet med den for det videre $\varnothing$ konomiske opsving afgørende valutareform i juni 1948 i de tre vestzoner.

Den fascistiske krigsfinansiering havde ødelagt penge- og kreditsystemet $\mathrm{i}$ Tyskland. Inflationen kunne kun opdæmmes gennem rigorøse prisstop. I hvilket omfang den tyske valuta var $\varnothing$ delagt efter den anden verdenskrig tydeligg øres ved, at der trods skarp overvågning og forbud havde udviklet sig en cigaretvaluta "på det sorte marked «: cigaretter, og ikke længere gyldige statslige papirpenge med tvangskurs, fungerede som cirkulationsmidler. Således var det klart, at en valutareform, dvs. en nedskrivning af valutaen, var nødvendig. Fra tysk side blev der også fremsat flere hundrede reformplaner, deraf nogen - som de münchiske fagforeningers plan - som kombinerede planer for en valutareform med en byrdefordelingsordning. Men til sidst blev valutareformen dog udformet af USbesættelsesmagten; og den blev tilpasset til de fremtidige betingelser for kapitalakkumulationen. Idet nemlig kun valutaen blev nedskrevet, blev pengesummen reduceret - alt i alt til ca. 6,5\% af den oprindelige værdi. En lignende værdiformindskelse af fast ejendom fandt ikke sted. Trods nogle særordninger for banker (dannelse af udligningsfordringer) betød denne ordning to ting: For det første en reduktion af den industrielle kapitals gæld i forhold til den rentebærende kapital, altså også en forbedring af fordelingsforholdet mellem industriel profit og rente til fordel for den industrielle kapital; og for det andet en reduktion af alle små opsparingsbeløb hos lønarbejderklassen. Bestræbelsen på i de småborgerlige lag af proletariatet enten at komme ud af den proletariske afhængighed gennem opsparing af en lille pengeformue - bestyrket yderligere gennem en fascistiske

41. Jvf. hertil H. H. Hartwich, Sozialstaatspostulat und gesellschaftlicher status quo, Köln og Opladen 1970, s. 62ff. Hartwich viser indgående, at ifølge US-besættelsespolitikken måtte den privat $\varnothing$ konomiske genopbyggelse og dermed styrkelsen af den kapitalistiske produktionsmåde gå forud for en politisk løsning. 
propaganda - eller at sørge for alderdom, sygdom, uarbejdsdygtighed, uddannelse etc., blev således for anden gang indenfor en generation modarbejdet gennem brutal tilegnelse.

Det er ikke her muligt at gå udførligt ind på denne genoprettelsesproces af kapitalherredømmet efter den anden verdenskrig. De $\varnothing$ konomiske forhold understøttede denne proces. For at bevise dette skal blot anføres nogle tal. Trods krigsødelæggelser og demontager, hvis betydning i reglen overvurderes ${ }^{42}$, lå værktøjsmaskinebestanden i 1945 i Vesttyskland mindst 33\% over niveauet for 1938, mens det i Frankrig kun var steget 9\% i det samme tidsrum ${ }^{43}$. Heraf følger, at det militære og politiske nederlag for det tyske borgerskab i 1945 ikke umiddelbart kan ligestilles med et $\varnothing$ konomisk nederlag. Heller ikke den arbejdsdygtige befolkning - i det mindste i de tre vestzoner - var blevet decimeret af krigstab. Tværtimod, den steg fra maj 1939 som følge af flygtninge tilvandringen fra 39,4 millioner til 44 millioner i oktober 1946. En lignende stigning kan vi fastslå i beskæftigelsen. Den var allerede i slutningen af 1946 større end i 1936, 11,8 millioner i forhold til 11,2 millioner ${ }^{44}$.

Således fremkommer - groft skitseret - følgende billede ved slutningen af 1940'erne i Vesttyskland: For det første har det vist sig for det vesttyske borgerskab, at det militære og politiske nederlag på ingen måde implicerer det $\varnothing$ konomiske nederlag. Den fascistiske form for borgerskabets politiske herredømme var ødelagt; men ikke det magtforhold, der var grundliggende for det. For det andet var nyordningsforestillingerne for arbejderklassens organisationer strandet, frem for alt ved modstanden fra US-besættelsesmagten, der anvendte Vesttyskland som spydspids mod den fremvoksende socialistiske lejr. For det tredje stod produktionskapaciteterne i vigtige områder, trods krigsødelæggelser og demontager, intakte, så man kunne begynde med produktionen, såfremt valoriseringsbetingelserne havde forbedret sig. For det fjerde stod kapitalen, trods krigstab på menneskeliv, på ingen måde ringere, men havde endog forøget antallet af udbyttelige arbejdskræfter, f.eks. arbejdere med meget høje kvalifikationer. For det femte havde den valutareform, som USbesættelsesmagten de facto gennemførte, sørget for, at den industrielle kapital i stor udstrækning kunne gøres gældfri og samtidig blev »den lille mands « sparepenge radikalt reduceret. For det sjette blev efter valutareformen prisstoppet ophævet, mens lønstoppet foreløbigt blev opretholdt indtil slutningen af 1948, hvad der i kapitalakkumulationens begyndelsesfase førte til en vigtig reduktion af den under alle omstændigheder elendige realløn.

Derfor er det intet under, at det høje udbytningsniveau, terroristisk fremtvunget under fascismen, foreløbigt kunne opetholdes og senere - som vi skal

42. Jvf. dertil fremstillingen af H. Heininger, Der Nachkriegszyklus der Westdeutschen Wirtschaft, Berlin (DDR) 1959, s. 60 ff., der underkaster de forskellige beregninger af krigstab og demontager en kritisk undersøgelse.

43. H. Heininger, op.cit., s. 56.

44. H. Heininger, op.cit., s. $146 \mathrm{f}$. 
Figur 2:

Udviklingen i kapitalproduktiviteten $\mathrm{Y} / \mathrm{K}$, lønkvoten w, væksten i kapitalstocken gK og i kapitalrentabiliteten pi i årene 1950-1959 (tallene gælder for industri og håndværk).

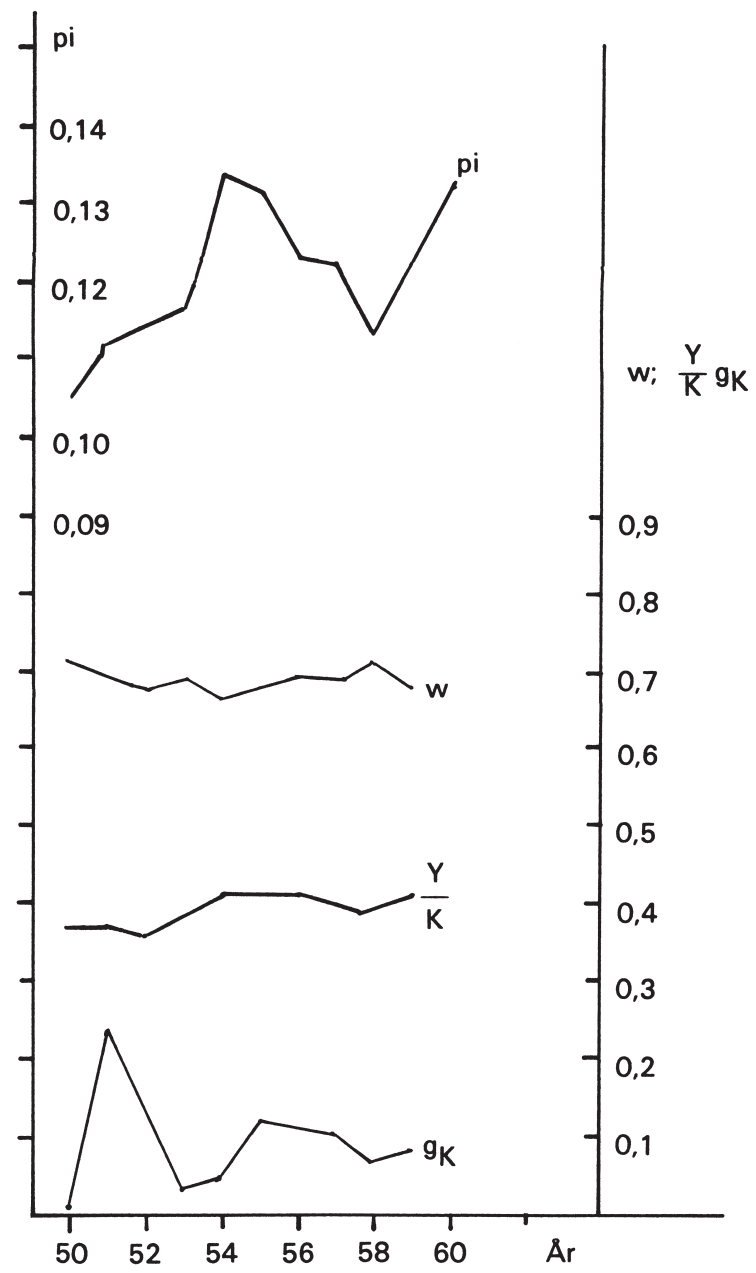

Kilde:

Egne beregninger på basis af data fra W. G. Hoffmann, Das Wachstum der deutschen Wirtschaft seit Mitte des Neunzehnten Jahrhunderts, Berlin/Heidelberg/New York 1965. 
vise - endog kunne forhøjes. På grund af den svækkede og politisk retløse arbejderklasser og på grund af det høje antal arbejdsløse kunne kapitalen producere til lave lønomkostninger. Således kommer - alt efter beregningsmetoden - unders $\emptyset$ gelser af arbejderklassens situation til det resultat, at reallønnen for de vesttyske arbedere først i 1950 (ifølge Wallich) eller først i 1956 (ifølge Kuczynski) igen nåede niveauet for $1938^{45}$. Holder man sig for øje, at levestandarden i 1938 lå under det niveau, der var før den økonomiske verdenskrise, så blive det tydeligt, under hvilke gunstige forhold den vesttyske kapital befandt sig efter den anden verdenskrig, så snart den igen kunne begynde at akkumulere. Dette var efter valutareformen i stor udstrækning tilfældet. Således kan det ikke undre, at kapitalrentabiliteten under disse omstændigheder, dvs. ved stagnerende eller endog faldende lønkvote og ved stigende kapitalproduktivitet, meget hurtigt i begyndelsen af 50'erne igen kunne nå det niveau, der terroristisk var blevet nået under fascismen. Ved hjælp af vores figur 2 (s. 31) kan denne udvikling eftervises: betragtet i sammenhæng med figur 1 viser det sig, at årene fra 1945 til 1950 ikke har været andet end en »afbrydelse « $i$ kapitalens kontinuitet fra fascismen til forbundsrepublikken Tyskland og de skal snarere indplaceres som rensende $\mathrm{i}$ den kapitalistiske rationalitets betydning end som en ny begyndelse.

\section{Komponenter og tendenser for kapitalakkumula- tionen i Vesttyskland fra 1950 til 1970}

\subsection{Kapitalforholdets kontinuitet}

Hidtil har vi forsøgt at fremstille de betingelser, der før eksistensen af BRD som politisk formation er blevet frembragt i den $\emptyset$ konomiske verdenskrise, fascismen, krigen og den umiddelbare efterkrigstid, og som bestemte retningen og tempoet for kapitalakkumulationen siden 50'erne. De almene udviklingstendenser for kapitalakkumulationen i Vesttyskland interesserer os imidlertid ikke som sådan, men kun hvis kendskabet dertil kan give oplysning om, hvilke betingelser der er fremherskende idag, hvilke der kan forventes og hvilke konsekvenser der må drages deraf for udarbejdelsen af en taktik for arbejderbevægelsen. I den forstand betragter vi udviklingstendenserne i 50'erne og 60'erne især ud fra synsvinklen, hvilke $\varnothing$ konomiske og politiske forhold er i denne

45. H. C. Wallich, Triebkräfte des deutschen Wiederaufstiegs, Frankfurt 1955, s. 78ff.; J. Kuczynski, Die Geschichte der Lage der Arbeiter unter dem Kapitalismus, Bd. 7a, Berlin (DDR) 1963, s. 386. Først i slutningen af 1948 bliver gennem det økonomiske råd (Wirtschaftsrat) det lønstop ophævet, der de facto har bestået siden 1933. 
fase blevet frembragt og hvilke bliver relevante for den videre udvikling af kapitalforholdet i 70'erene.

De almene udviklingstendenser for kapitalakkumulationen kan fremstilles tydeligt ved hjælp af figur 3 (eller tabel 2). Kapitalrentabiliteten er straks ved begyndelsen af 50'erne meget $h \varnothing j$. I den første halvdel af 50'erne stiger den fortsat for derefter at antage en entydig faldende tendens. Denne tendens fortsætter - for så vidt det vides - også i 70'erne. Kapitalrentabilitetens bevægelse kan føres tilbage til bevægelserne i kapitalintensiteten, arbejdsproduktiviteten og lønkvoten. Sammenhængen mellem disse størrelser fremgår af den allerede i Kurasje 12 udviklede relation mellem arbejdsproduktivitet, lønkvote eller komplementen til lønkvoten, profitraten, og kapitalintensiteten. Udfra den statistisk beviselige bevægelse i disse størrelser kan der gives følgende grove angivelse af kapitalakkumulationens udviklingstendenser:

Stigningen i kapitalrentabiliteten i 50'erne skyldes den lave vækst i kapitalintensiteten, den hurtige vækst i arbejdsproduktiviteten og den lave lønkvote. Til grund for kapitalrentabilitetens faldende tendens siden slutningen af 50'erne ligger derimod en meget høj vækstrate for arbejdsproduktiviteten og en stigende lønkvote. Den stadig stigende arbejdsproduktivitet blev købt med en hurtigere stigning i kapitalintensiteten, så at også kapitalproduktiviteten falder siden anden halvdel af 50' erne $^{46}$. Disse udviklingstendenser, der her er fremstillet i borgerlige kategorier, kan også skitseres på grundlag af den marxske teori.

I 50'erne foregik merværdiproduktionen uden større stigning i indsatsen af konstant kapital pr. arbejder, altså uden betydelig vækst i den tekniske og organiske kapitalsammensætning. Ved en høj merværdirate, der skyldtes værdiformindskelsen af arbejdskraften gennem $\emptyset$ konomisk verdenskrise, fascisme, krig, betød den hurtige tilvækst i beskæftigelsen en lige så hurtigt voksende værdiproduktion, og derfor også merværdiproduktion. Under disse omstændigheder med en høj merværdirate og med en kun langsomt stigende organisk sammensætning af kapitalen måtte profitraten ligeledes være meget høj. Men siden slutningen af 50'erne bliver kapitalen for at opnå stigning i merværdiproduktionen i stigende grad henvist til den relative merværdis produktionsmetoder. Forhøjelsen af arbejdets produktivkraft resulterer ganske vist $i$ en værdiformindskelse af arbejdskraften, men den nødvendige stigende indsats af konstant kapital, der skal til for at opnå dette resultat, medfører samtidig den accelerende stigning i kapitalens organiske sammensætning. Konsekvensen er en tendentiel faldende profitrate. Anderledes udtrykt: Stigningen i merværdiraten kan ikke kompensere eller overkompensere for den negative virkning på profitraten af stigende organisk sammensætning.

Efter disse globale udsagn er det muligt groft at inddele udviklingsfasen for kapitalismen i Vesttyskland efter den anden verdenskrig. På grund af de særlige

46. Jvf. dertil også Sachverständigenrat zur Begutachtung der gesamtwirtschaftlichen Entwicklung, Jahresgutachten 1969/70, tabel 3. 
Figur 3:

Udvikling i kapitalrentabiliteten pi, lønkvoten w, arbejdsproduktiviteten $\mathrm{Y} / \mathrm{L}$ og i kapitalintensiteten $\mathrm{K} / \mathrm{L}$ i industrien i Vesttyskland.

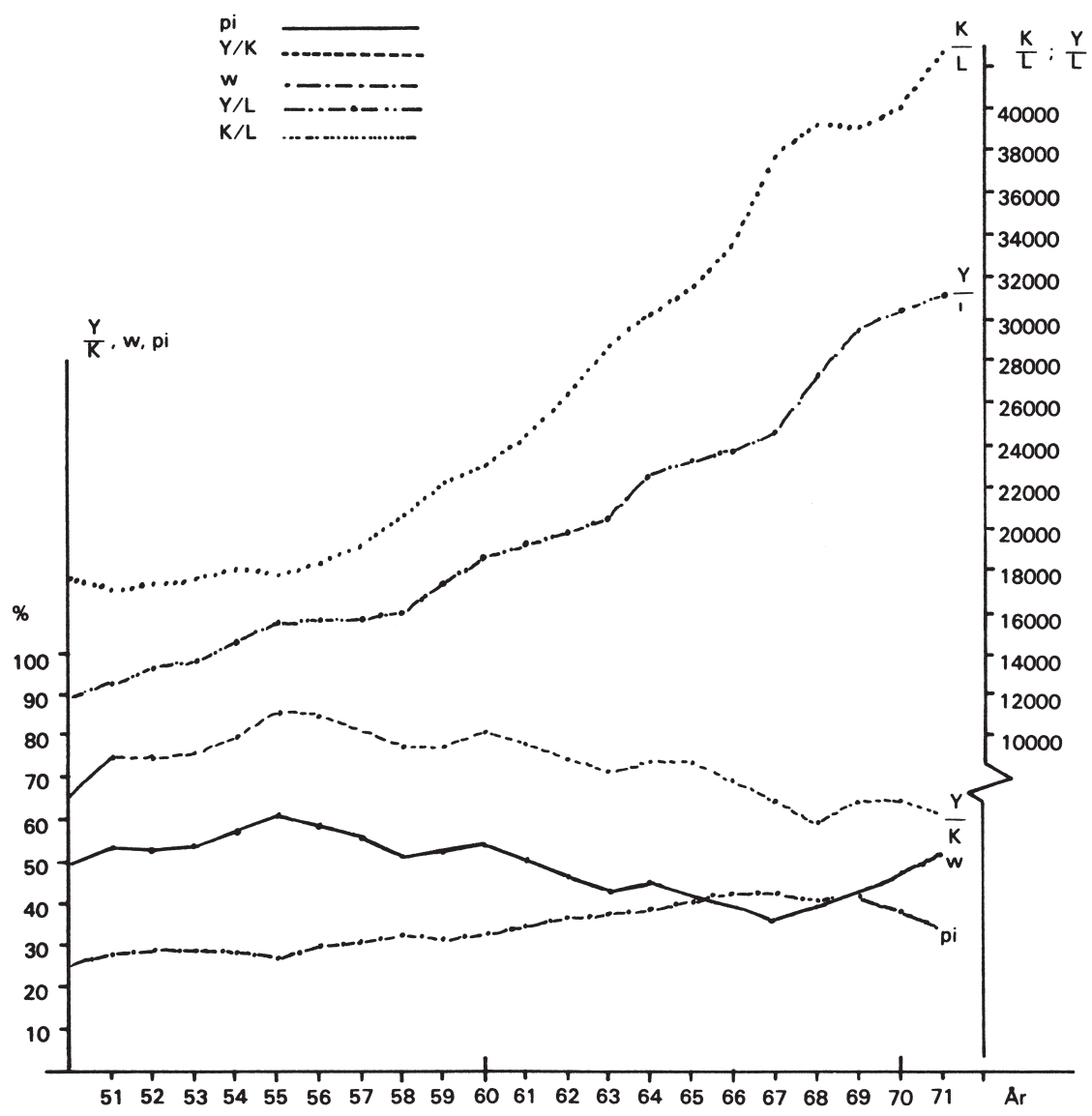

Kilde:

Egne beregninger og Krengel, o.a., Produktionsfaktoren und potential; se ivørigt tabel 2. 
Tabel 2:

Kapitalrentabilitet $\mathrm{i}$ industrien.

\begin{tabular}{|c|c|c|c|c|c|c|}
\hline År & $\mathrm{Y} / \mathrm{K}$ & $\begin{array}{l}\text { Y/L (= effek- } \\
\text { tiv nettopro- } \\
\text { duktions- } \\
\text { volume pr. } \\
\text { beskæftiget) }\end{array}$ & $\begin{array}{l}\mathrm{K} / \mathrm{L}(=\text { brut- } \\
\text { toanlægs- } \\
\text { formue pr. } \\
\text { beskæftiget) }\end{array}$ & w & $(1-w)$ & pi \\
\hline 1950 & 0,667 & 11952 & 17927 & 0,264 & 0,736 & 0,491 \\
\hline 1951 & 0,750 & 12777 & 17045 & 0,284 & 0,716 & 0,537 \\
\hline 1952 & 0,757 & 13222 & 17475 & 0,294 & 0,706 & 0,534 \\
\hline 1953 & 0,765 & 13615 & 17796 & 0,298 & 0,702 & 0,537 \\
\hline 1954 & 0,809 & 14589 & 18034 & 0,288 & 0,712 & 0,576 \\
\hline 1955 & 0,862 & 15515 & 17989 & 0,289 & 0,711 & 0,613 \\
\hline 1956 & 0,852 & 15730 & 18454 & 0,307 & 0,693 & 0,590 \\
\hline 1957 & 0,821 & 15831 & 19298 & 0,317 & 0,683 & 0,561 \\
\hline 1958 & 0,783 & 16165 & 20645 & 0,330 & 0,670 & 0,525 \\
\hline 1959 & 0,785 & 17351 & 22113 & 0,325 & 0,675 & 0,530 \\
\hline 1960 & 0,815 & 18770 & 23032 & 0,331 & 0,669 & 0,545 \\
\hline 1960 & 0,812 & 18702 & 23028 & 0,333 & 0,667 & 0,542 \\
\hline 1961 & 0,791 & 19246 & 24346 & 0,355 & 0,645 & 0,510 \\
\hline 1962 & 0,757 & 19918 & 26304 & 0,378 & 0,622 & 0,471 \\
\hline 1963 & 0,727 & 20688 & 28440 & 0,389 & 0,611 & 0,444 \\
\hline 1964 & 0,746 & 22487 & 30136 & 0,391 & 0,609 & 0,454 \\
\hline 1965 & 0,741 & 23334 & 31504 & 0,413 & 0,587 & 0,435 \\
\hline 1966 & 0,706 & 23811 & 33748 & 0,433 & 0,567 & 0,400 \\
\hline 1967 & 0,653 & 24749 & 37913 & 0,430 & 0,570 & 0,372 \\
\hline 1968 & 0,700 & 27479 & 39238 & 0,418 & 0,582 & 0,407 \\
\hline 1969 & 0,754 & 29508 & 39127 & 0,428 & 0,572 & 0,431 \\
\hline 1970 & 0,755 & 30254 & 40049 & 0,483 & 0,517 & 0,390 \\
\hline 1971 & 0,729 & 31098 & 42648 & 0,520 & 0,480 & 0,350 \\
\hline
\end{tabular}

Kilde:

på basis af data fra: R. Krengel o.a., Produktionsvolumen und -potential, Produktionsfaktoren der Industrie im Gebiet der Bundesrepublik Deutschland, Statistische Kennziffern, 13. Folge, 1950 bis 1960, Berlin 1973; sammes, Statistische Kennziffern, 12. Folge, 1960 bis 1971, Berlin 1972.

Tal efter 1960 indbefatter Saarland. (I priser pr. 1962; w blev beregnet på basis af norminalløn!). $\mathrm{pi}=\mathrm{Y} / \mathrm{K}(1-\mathrm{w})$. 
historiske omstændigheder efter den anden verdenskrig, altså på grund af de sarlige og på ingen måde typiske forudsætninger for kapitalakkumulationen kan der udskilles to faser, der nassten modsvarer de to årtier 50'erne og 60'erne. Derfor har vi også inddelt vor fremstilling modsvarende denne inddeling.

Vi er klar over problematikken ved en periodisering af den kapitalistiske udvikling, da den ofte kommer i stand ved vilkårlige inddelingskriterier p.gr.a. muligheden af manipulationer med datamateriale eller p.gr. a. fejlagtige teoretiske ansatser. Derfor må det tydeligt understreges på dette sted, at den følgende periodisering hverken har noget at gøre med den muligvis fornuftige inddeling efter årtier, der hviler på statistiske præmisser, eller med den anvendte inddeling $\mathrm{i}$ en extensiv og en intensiv udviklingsfase, der hviler på den neoklasiske vækstteoris forestillinger ${ }^{47}$.

Vor periodiseringskriterium kan snarere formuleres som følger: I begyndelsen og indtil midten af 50'erne er de betingelser, der blev skabt under fascismen, krigen og i den umiddelbare efterkrigstid, stadigvæk fremherskende for kapitalakkumulationen. Det er så at sige en under kapitalistiske udviklingsbetingelser atypisk fase, hvis forudsætninger og grundlag forsvinder i løbet af udviklingen. Hvorfor og hvordan dette sker, bliver nedenfor fremstillet nøjere.

Anden halvdel af 50'erne kan betegnes som »omvæltningens fase «, i hvilken de overleverede gunstige forudsætninger svinder væk, men alligevel i afsvækket form fortsat er virksomme. Først efter 1958/60 er den vesttyske kapitalisme kommet tilbage til »det normale«. Siden den tid viser det sig, at de modsigelser, der udvikler sig i kapitalakkumulationsprocessen, kan skærpes til kriseagtig tilspidsning.

I denne fase af den vesttyske kapitalisme har således de kapitalakkumulationsbetingelser, der opstod under fascismen og i løbet af den anden verdenskrig, stadigvæk eftervirkninger. Reproduktionen af kapitalforholdet sker næsten krisefrit. Ganske vist sætter også kapitalakkumulationens tendenser sig igennem i cyklisk form i 50'erne og i første halvdel af 60'erne. Men før 1967 tilspidses de aldrig til en skarp krise. Krisen som »renselses « form for de modsigelser, der opstår i løbet af kapitalakkumulationen, var overflødig. I denne fase med høje økonomiske vækstrater, som de aldrig før var opnået i kapitalismens historie, kunne derfor de teorier, der postulerede senkapitalismens krisefrihed eller den principielle statslige manipulerbarhed med økonomien, overfladisk betragtet refererer til »realiteten «. Deres grundfejl var og er i den forbindelse, at de ikke har undersøgt kapitalakkumulationens udviklingsfase ud fra dens særskilte, usædvanlige omstændigheder og ikke har taget hensyn til, at netop de usædvanlige gunstige betingelser for en fremskyndet kapitalak-

47. Som det kan ses af figur 3, falder kapitalrentabiliteten siden 1955. I dette tidsrum bliver opløsningen af den industrielle reservearmé desuden i tiltagende grad tydelig. (Jvf. dertil senere fremstillingen af »beskæftigelsesskranken). Til kritik af en sådan grov periodisering jvf. Projekt Klassenanalyse, op.cit. s. $56 \mathrm{ff}$. 
kumulationsproces forsvinder i løbet af denne proces og da også fører det vesttyske $\varnothing$ konomiske mirakel«-kapitalisme tilbage til den cykliske bevægelses normalitet, dvs. periodisk frembrydende kriser $^{48}$.

På den anden side udvikles i denne tid alle de økonomiske, sociale og politiske momenter, der indtil i dag udgør den ordsprogsagtige »stabilitet « i det vesttyske samfund. Vi skal på dette sted kort gå ind på de vigtigste fremtrædende betingelser ${ }^{49}$.

(1). Der opstår en branchestruktur, der gør Vesttyskland til - i sammenligning med alle andre udviklede kapitalistiske lande - det mest højindustrialiserede land (målt $\mathrm{i}$ antallet af de i industrien beskæftigede arbejdskræfter) og som netop forudbestemmer den vesttyske kapital til sin stærke stilling på verdensmarkedet ${ }^{50}$.

Den traditionelle branchestruktur med hovedvægten på maskinbygning, kemi-, jern- og stålindustri og på bilindustri var stadig en forudsætning for den vesttyske kapitals gunstige stilling på verdensmarkedet. Den expanderende efterspørgsel på verdensmarkedet ved Koreakrigens begyndelse og de forbedrede valoriseringsbetingelser for kapitalen førte i alle højtudviklede lande til en stigning i importefterspørgslen. I sammenhæng med genoprettelsen af verdensmarkedet blev der iværksat foranstaltninger til nedbrydning af toldskranker og andre handelshindringer gennem dannelse af økonomiske- og toldmæssige fællesskaber (Kul- og Stålunionen i 1952 og EEC 1957) og nedbrydningen af konvertibilitetsskrankerne for valutaerne. Udvidelsen af markederne og masseproduktionen muliggjorde på sin side også indførelsen af nye produktionsmetoder i Vesttyskland, der havde været urentable indenfor det begrænsede nationale marked.

Sammenbruddet af verdensmarkedet under den $\varnothing$ konomiske verdenskrise var en væsentlig grund til skærpelsen og omfanget af krisen, da de exportorienterede industrier herigennem mistede deres markeder; derfor bliver det almene opsving på verdensmarkedet i 50'erne og den gunstige konkurrencestilling for den vesttyske kapital til en væsentlig faktor for den accelererende kapitalakkumulation.

Således stiger andelen af udenrigsomsætningen indenfor den vesttyske industri fra 8,3\% i 1950 til 20\% i 1972. Vesttyskland bliver på denne måde det andet største verdenshandelsland efter USA. I 1971 ligger dets andel af verdensudførslen på $11,28 \%{ }^{51}$.

48. Erfaringen fra en periode med relativ krisefri og hurtig kapitalistisk udvikling virker endnu i dag tilbage på teorierne, der - som hos Habermas og også hos Offe - negerer de indre modsigelser i den kapitalistiske akkumulation i »senkapitalismer « og det betegnes som en »orthodox « position, når man fastholder det kapitalistiske samfunds grundlæggende kriseagtighed. Jvf. J. Habermas, Legitimationsprobleme im Spätkapitalismus, Frankfurt a.M. 1973, s. 73 ff.

49. Udgår.

50. Jvf. også G. Fels, Probleme der Arbeitsteilung zwischen Industrie- und Entwicklungsländern, i: Die Weltwirtschaft, Heft 1 (1971); do. Der Wandel der weltwirtschaftlichen Arbeitsteilung und seine Konzequenzen für die Branchenstruktur der Westdeutschen Wirtschaft, i: WSI-Studien, nr. 22, Köln 1973.

51. Statistisches Jahrbuch 1973, s. 72; Börsen und Wirtschaftshandbuch 1973, Frankfurt a.M. 1973, s. 218. 
Denne stærke stilling for den vesttyske kapital på verdensmarkedet fører imidlertid blot til en stærk verdensmarkedsafhængighed i betydningen afhængighed af efterspørgselsudviklingen på verdensmarkedet. Men det har også konsekvenser for kapitalens reproduktionsstruktur, idet realiseringsbetingelserne for de producerede værdier i Vesttyskland på det udenlandske marked bliver et afgørende moment i kapitalcirkulationen. Med andre ord: den traditionelle branchestruktur, der var forudsætningen for exportevnen, stabiliserer sig stadig i løbet af udviklingen. Branchestrukturen, således som den har udviklet sig i Vesttyskland, er kun »passende «, hvis realiseringsmulighederne på verdensmarkedet bliver bevaret og stadigvæk udvides - da de kapitaler, der er anlagt i disse brancher, må akkumulere og følgeligt må producere stadig flere varer.

I meget større grad end andre nationale kapitaler er den vesttyske kapital derfor interesseret $i$, at verdensmarkedet expanderer og protektionistiske foranstaltninger fjernes. På den anden side opstår der p.gr. a. denne struktur uligheder og kriser på verdensmarkedet. Det strukturelle overskud af export i forhold til import, der har gjort sig gældende (for BRD) siden begyndelsen af 50'erne, betyder for andre lande et lige så strukturelt handelsbalanceunderskud. Med tiden må dette føre til betalingsudygtighed for enkelte lande.

Verdensvalutakriser, som de regelmæssigt har indtruffet siden begyndelsen af 60'erne, er altså også - vi går ikke ind på andre momenter ${ }^{22}$ - en følge af den branchestruktur, der har udviklet sig i løbet af kapitalakkumulationen i Vesttyskland.

(2) Yderligere en forudsætning er fremkommet for det vesttyske samfunds udvikling i denne tid: den politiske stabilitet og den borgerlige stats også i dag stærke legitimationskraft. Dette må interpreteres som en følge af den vidtgående $\varnothing$ konomiske krisefrihed. Årsagerne til denne $\varnothing$ konomiske krisefrihed er allerede kort blevet antydet og vil i det følgende blive mere udførligt fremstillet. Imidlertid ville analysen blive ensidig, hvis der ikke også blev henvist til statens rolle i denne proces. Det afgørende punkt i den forbindelse er, at betingelserne for kapitalakkumulationen ikke længere skulle fremstilles af den vesttyske stat. Derved var det muligt at lade tingene udvikle sig »liberalt«.

Alle ansatser f.eks. fra SPD's og fagforeningernes side efter krigen og i de tidlige 50'erne til forstærket $\varnothing$ konomisk planlægning fra statens side måtte konsekvent integreres i et koncept for socialistisk transformation af samfundet, som slet ikke forelå og fremfor alt efter 1948/52 heller ikke kunne have støttet sig til nogen udviklet social bevægelse. Statslig politik kunne iøvrigt i denne fase kun være passende for kapitalakkumulationens betingelser, hvis den begunstigede kapitaldannelsen på den måde, at staten gjorde krav på så få

52. Jvf. dertil Chr. Neusüss, B. Blanke, E. Altvater, Kapitalistischer Weltmarkt und Weltwährungskrise, i: Probleme des Klassenkampfs. nr. 1 (1971); Busch/Schöller/Seelow, Weltmarkt und Weltwährungskrise, Bremen 1971. 
ressourcer som muligt. Dette forhold mellem kapitalakkumulation og statslig politik blev ganske tydeligt ved oprustningen af forbundshæren. I en fase, hvor der allerede var knaphed på arbejdskraft, skulle inden for få år nogle hundrede tusinde mænd i den arbejdsdygtige alder unddrages produktionen. For dog ikke at sinke kapitalakkumulationen gennem disse foranstaltninger blev opbygningen af forbundshæren gjort langsommere ${ }^{53}$.

Ganske vist kan dette ikke betyde, at staten overhovedet ikke gjorde indgreb i kapitaldannelsen. Det kan kun betyde, at dens indgreb alle sammen gik ud på at fremskynde kapitalakkumulationen på den måde, at staten selv gav afkald på beslaglæggelse af økonomiske ressourcer. Eksempel herpå er de tilsigtede foranstaltninger til udvikling af grundstofindustrien med »investeringshjælpeloven ${ }^{54}$. I den forbindelse drejer det sig om en omfordelingforanstaltning mellem forskellige brancher ved statshjælp for at fremstille de stoflige forudsætninger for en accelerede akkumulation. Da de subventionerede branchers produkter blev prisbundet, kunne den indskudte kapital til råstoffer og investeringsgoder i andre brancher holdes lave. Karakteren af denne foranstaltning er entydig: Staten sørgede for, at der indenfor kapitalen blev omfordelt produktionsmidler, uden at den havde trukket en del af midlerne til sig for selv at gennemføre investeringerne. I denne sammenhæng skal også nævnes det i første halvdel af 50'erne vigtige skattemæssige incitamentsystem. Gennem den ofte modificerede skattelovgivning (særlig med den 7'ende paragraf i EStG) blev degressive afskrivningsmetoder muliggjort, som netop virkede som tvang til kapitaldannelse fra skattelovgivningens side ${ }^{55}$. Derudover antog den statslige underst $\varnothing t t e l s e$ af akkumulationen også direkte form af en skattefritagelse for profit og investeringer, hvorigennem kapitalens selvfinansiering og akkumulation direkte blev påvirket.

Forskellen mellem understøttelsen af kapitalakkumulationen under fascismen og de i midten af 60'erne udviklede konjunkturpolitiske instrumenter ligger $i$, at staten ikke her var virksom gennem efterspørgselsstimulans, ikke gennem udvidelsen af den statslige forbrugs- og investeringsefterspørgsel og heller ikke gennem et sektoralt indgreb i kapitalreproduktionen, men den understøttede kapitaldannelsen på global måde. I den forbindelse skulle staten og dette fandt sit udtryk i den neoliberale samfundsteori - tiltrække så få økonomiske ressourcer som muligt og snarere overlade disse til privat anvendelse. Denne tendens kan bevises ved hjælp af tal over statsudgifternes andel af nationalindkomsten efter den anden verdenskrig. Steg statsforbruget i tiden mellem første og anden verdenskrig fra $14 \%$ til $26 \%$ - hvori kun genspejles den

53. Jvf. dertil Gerhard Brandt, Rüstung und Wirtschaft in der Bundesrepublik, Witten og Berlin 1966, særlig s. $75 f f$.

54. Jvf. ang. virkningen af »investeringshjælpeloven« fremstillingen hos Wallich, op.cit., Hartwich op.cit. og J. Huffschmid, Die Politik des Kapitals, Frankfurt a.M. 1969.

55. Den degressive afskrivning gik ud på, at dele af profitten ikke blev beskattet, når den blev reinvesteret; jo højere reinvestering, desto højere skattefri profit. Jvf. ang. lovens mekanisme særlig Hartwich op.cit. 
enorme stigning i rustningsudgifterne -, så ligger andelen af statsforbruget af nationalindkomsten i gennemsnit fra 1950/54 på 17,5\% og falder endog yderligere. I 1955/59 ligger statsforbruget modsvarende på 15,6\% $\%^{56}$. Dette fald i det offentliges forbrug modsvarer på den anden side en stigning i de private investeringer.

Med den økonomiske rekonstruktion restaureredes også kapitalens politiske herredømme. Denne restauration finder sit tydelige udtryk i den skridtvise undertrykkelse af fagforeningernes krav om delnationalisering (Teilvergesellschaftung), medbestemmelse og økonomisk planlægning allerede i begyndelsen af $50{ }^{\prime} e^{2 n} e^{57}$, i den hurtige styrkelse af de borgerlige partier, fremfor alt $\mathrm{CDU} / \mathrm{CSU}$, i genoprettelsen af det militære magtapparat gennem oprustningen af forbundshæren, i forvandlingen af SPD's selvforståelse fra klasseparti til »folkeparti«, i integrationen af Vesttyskland i de militære, politiske og $\varnothing$ konomiske pagtsystemer for de kapitalistiske stater osv. - Ganske vist er der blevet dannet politiske bevægelser mod ethvert skridt af politisk restauration mod oprustningen, mod den atomare bevæbning, mod nødretslovene -, men de endte altid i politiske nederlag, hvoraf der blev draget lære, men som dog vanskeliggør enhver ny begyndelse på politisk opposition.

Vesttysklands politiske historie skal ikke skrives her; derfor må denne opregning af enkelte momenter i restaurationen af kapitalens politiske herredømme være tilstrækkeligt. Vigtig i vores sammenhæng er, at gennem denne restauration er de »rammebetingelser« for kapitalakkumulationen, der også er relevante i dag, blevet produceret.

(3). Den hurtige vækst i værdiproduktet produceret af de produktive arbejdere muliggjorde i hele udviklingsfasen fra begyndelsen af 50'erne til første halvdel af 70'erne - kun med korte afbrydelser i kriseåret 1967/68 - regelmæssige reallønstigninger, uden at man behøvede at føre kraftige $\varnothing$ konomiske kampe herfor. Ganske vist har der i BRDs historie været en række svære og langvarige strejker - de vigtigste eksempler: Bayernstrejken i 1954, metalarbejdernes strejker i Slesvig-Holstein i 1956/57, i Baden-Württenberg i 1963 og $1971^{58}$, - men de har aldrig for alvor kunnet forstyrre kontinuiteten i kapitalens reproduktionsproces, således som det er sket $\mathrm{i}$ andre kapitalistiske lande - $\mathrm{i}$ Italien, Storbritannien og Frankrig - siden anden halvdel af 60'erne.

Den kendsgerning, at arbejderklassens reproduktionsniveau kontinuerligt er blevet forbedret, har med tiden givet sig udtryk i en vidtgående $\varnothing$ konomisk borgfred fra fagbevægelsens side. Forliset af deres nyordningsforestillinger umiddelbart efter den anden verdenskrig, det umulige $i$ at omsætte

56. W. G. Hoffmann op.cit. s. 108.

57. Jvf. f.eks. de i DGB's münchener program fremhævede krav, 1949.

58. Jvf. dertil det snart hos Europäischen Verlagsanstalt Köln-Deutz fremkommenden studie af Bergmann, Jacobi og Müller-Jentsch, Gewerkschaften in der BRD (p.t. ikke offentliggjort manuskript). 
konceptionen af den expansive lønpolitik (Agartz) i praksis, perspektivløsheden ved en politik, der sigter mod systemforandring og ved anknytningen til det SPD, der hurtigt lader sig integrere i det herskende samfund og ved den stadig skærpede antikommunisme, alt dette førte til erstatningsstrategier, med hvilke enkelte forbedringer ganske vist blev opnået, men samtidig blev grundlæggende ændringer af de samfundsmæssige forhold implicit eller også explicit forkastet.

Også efter den første store krise i 1967 fastholdt fagbevægelsen sin integrationspolitik. De spontane strejker i 1969 og i 1973 var svar herpå. Men dermed har de grundlæggende forbindelser mellem klasserne og klasseorganisationerne på ingen måde forandret sig, så trods den betydning de spontane strejker har haft for den politiske rekonstruktion af den organiserede arbejderbevægelse, må deres relevans for kapitalreproduktionens betingelser ikke overvurderes. Mens der p.gr.a. klassekampe har været afbræk i kontinuiteten i kapitalakkumulationen i de vesteuropæiske lande, der konkurrerer med den vesttyske kapital, bliver den udvidede reproduktion af Vesttysklands kapital næsten slet ikke forstyrret af strejker. Strejker er p.gr.a. deres sjældenhed i de forløbende 25 år blevet til noget usædvanligt, ja næsten anstødeligt: Selv om de er formel mulige og lovlige har den restaurative udvikling de facto ført til en bandlysning af strejken, der sammen med den $\varnothing$ konomiske disciplinering af arbejderne bliver til et virksomt instrument for kapitalen, når reallønstigninger ikke længere kan opnås uden kampe. Denne udvikling i arbejderklassen og i klassekampene er i hvert fald i dag ansvarlig for, at den vesttyske kapitals stilling på verdensmarkedet i 70'erne både er absolut og relativt forbedret i forhold til andre kapitalistiske lande.

Således viser det sig, at de i dag herskende betingelser kun kan forstås, hvis deres historiske opståen bliver eftersporet. Dette skal nu ses under det begrænsede aspekt: undersøgelsen af kapitalakkumulationen i Vesttyskland.

\subsection{Profitrate og kapitalakkumulation i 50'erne}

\subsubsection{Profit og løn}

Det høje akkumulationstempo i begyndelsen af 50'erne skal fremfor alt bestemmes udfra den høje udbytningsrate. Denne er på sin side ikke så meget bestemt af arbejdets stigende produktivkraft, men snarere af det undertrykte konsumtionsniveau og den lave lønkvote under fascismen og krigen (jvf. figur 1 og 2).

En forklaring på den høje vækstrate i nationalproduktet ud fra den forhåndenværende kvalifikationsstruktur for arbejdskraften, således som Janossy fors $\emptyset$ ger, eller ud fra verdensmarkedsimpulser og statslig intervention (Maddison), eller ud fra opdæmmede behov efter krigen (Shonfield), eller også udfra 
»frigørelsen af det private initiativ«, således som de neoliberale gør ${ }^{59}$, er på ingen måde tilstrækkeligt for at begribe den accelerede vækst indenfor næsten alle strategiske $\varnothing$ konomiske st $\varnothing$ rrelser. Hvad havde det nyttet for kapitalen med kvalificerede arbejdskræfter, store brakliggende lagre af produktionskapaciteter, fortræffelige afsætningschancer på verdensmarkedet, en udvidelse af den statslige efterspørgsel, »intiativvenlige « arbejdsgivere, hvis det, som ville kunnet afsættes, ikke ville kunnet produceres med en tilstrækkelig høj - og i det vesttyske tilfælde endog med en usædvanlig høj - profitrate?

For kapitalen er først og fremmest produktionsbetingelserne afgørende for, om og i hvilken grad de muliggør en tilstrækkelig valorisering af den indskudte kapital. Det gælder i lige grad for enkeltkapitalen som for totalkapitalen, - her betragtet indenfor nationale rammer. Da kapitalværdien må cirkulere, bliver også realiseringsbetingelserne for de producerede værdier og merværdier betydningsfulde for valoriseringen. Men for at kunne realiseres, må de først produceres. Den enkelte kapitalist kan ganske vist mene, at han får profitten ved afhændelsen af de producerede varer. For totalkapitalen kan dette på ingen måde gælde. Den kan kun fuldbyrde profittens formforvandling til penge, hvis der virkelig også er blevet produceret. Værdi og merværdi eller profit opstår ikke ved realiseringen, men i produktionen - produktionsbetingelserne overfor realiseringsbetingelserne (efterspørgselsforholdene). Vi går ud fra, at det høje akkumulationstempo var muligt p.gr.a. den høje udbytningsrate, der er blevet terroristisk fremtvunget under fascismen og forstærket gennem krigen. Men hvordan kan det forklares, at den høje udbytningsrate i det første årti efter krigen er blevet opretholdt og endog forhøjet? Når vi i tabel 1 anvender det anførte forhold mellem kapitalindkomst og arbejdsindkomst i industri og håndværk som indikator, så viser det sig, at andelen af kapitalindkomsten $\mathrm{i}$ 50 'erne er steget. En vigtig grund til denne tendens var den forhåndenværende industrielle reservearme indtil anden halvdel af 50'erne.

I tabel 3 (s. 43) ses udviklingen af arbejdsløsheden i 50'erne. Først i 1955 falder arbejdsløsheden under 1 million og først mod slutningen af 50'erne går den så meget tilbage, at man kan tale om »fuld beskæftigelse«. Det store antal arbejdsløse har uden tvivl virket disciplinerende og har for det første haft indflydelse på fordelingsforholdet af nettoproduktet mellem lønarbejde og kapital til fordel for kapitalen, har for det andet muliggjort kapitalens akkumulation i en årrække, uden at den måtte forøge kapitalintensiteten som følge af knaphed på arbejdskraft og stigende lønninger.

Hertil kommer en yderligere faktor: nemlig i løbet af hele 50'erne var der en vedvarende tilstrømning af flygtninge fra de tidligere østområder og også

59. F. Janossy Das Ende der Wirtschaftswunder, Frankfurt 1968; A. Maddison, Economic Growth in the West, New York, London (Allen \& Unwin Ltd) 1964; A. Shonfield, Modern Capitalism, London, Toronto, New York 1965 (Oxford University Press); W. Eucken, Die Grundlagen der Nationalökonomie, Berlin, Göttingen, Heidelberg 1950. 
Tabel 3:

Arbejdsløsheden i Vesttyskland 1948-1960.

\begin{tabular}{l|c|l}
\hline År & $\begin{array}{l}\text { Registrerede } \\
\text { arbejdsløse } \\
\text { i } 1.000\end{array}$ & $\begin{array}{l}\text { Arbejdsløsheds- } \\
\text { kvotienter: }\end{array}$ \\
\hline 1948 & 451 & - \\
1949 & 1283 & - \\
1950 & 1580 & 10,4 \\
1951 & 1432 & 9,1 \\
1952 & 1379 & 8,5 \\
1953 & 1259 & 7,6 \\
1954 & 1221 & 7,1 \\
1955 & 928 & 5,2 \\
1956 & 761 & 4,2 \\
1957 & 662 & 3,5 \\
1958 & 683 & 3,6 \\
1959 & 476 & 2,5 \\
1960 & 235 & 1,2 \\
\hline
\end{tabular}

Kilde:

H. Wallich, Triebkräfte des deutschen Wiederaufstiegs, Frankfurt 1955, s. 274; og Jahresgutachten des Sachverständigenrates zur Begutachtung der gesamtwirtschaftlichen Entwicklung, Bundestagsdrucksache 7/1273, 1973, s. 206.

fra DDR. Alene fra 1945 til 1950 strømmede der 7,9 mio. flygtninge til Vesttyskland. Indtil 1961 var det pr. år mellem 330000 (1953) og 150 000(1959).

Disse flygtninge var på ingen måde en belastning for kapitalen som det ofte bliver fremstillet i »det $\varnothing$ konomiske mirakels« apologi. Deres funktion for akkumulationsprocessen - bortset fra kortvarige indlemmelsesproblemer - bestod snarere i tre ting: For det forste fyldte de stadig den industrielle reservearme op og trykkede dermed de beskæftigede arbejders lønninger $^{60}$. For det andet muliggjorde de den gnidningsløse tilførsel af ofte meget højt kvalificerede arbejdskræfter til produktionen. For det tredje producerede de - engang indlemmet i produktionsprocessen - på basis af den anvendte

60. Såldes skriver Gündel, Heininger, Hess, Zieschang, Die Labilität des Wirtschaftssystems in Westdeutschland, Berlin 1963, s. 59: »Flygtningene blev til en yderst frugtbar akkumulationskilde for den vesttyske kapital. På grund af deres elendighed tog de også under de sletteste betingelser mod arbejde, hvad der måtte få eftertrykkelig indflydelse på udbytningsbetingelserne og dermed hele reproduktionsprocessen «. 
teknologi i produktionsprocessen yderligere værdiog merværdimasser ${ }^{61}$, bidrog altså til stigningen i værdiproduktionen, der udtrykte sig i høje stigningsrater i nationalproduktet. Kort, den objektive funktion af de tilstrømmede flygtninge bestod $\mathrm{i}$ at forhindre betydelige lønstigninger i forbindelse med nedbrydningen af den industrielle reservearme og at muligg øre forhøjelsen af værdi- og merværdiproduktionen uden at forandre produktionsbetingelserne $\mathrm{i}$ de produktionsprocesser, som de blev indlemmet i.

Således gik det til, at forholdet mellem profit og løn (kapitalindkomst og arbejdsindkomst) forbedredes i forhold til tiden før den anden verdenskrig (tabel 1).

Nogle data fra den første halvdel af 50'erne kan yderligere vise dette (se tabel 4, s. 45). Tallene dokumenterer, at der p.gr.a. forlængede arbejdstid, stigende leveomkostninger og moderat stigende lønninger (39\% i bruttotimeløn) sikkert ikke kunne finde nogen forbedring sted i fordelingsforholdene. Ydermere må man vide, at produktiviteten pr. arbejdstime fra 1949 til 1954 tiltog med næsten $45 \%{ }^{62}$. Deraf kan man kun drage en slutning: Forholdet mellem lønninger og profitter blev dårligere sammenlignet med tiden før verdenskrigen. Hvis man tager 1936 som basis, så steg løn- og gagesummen indtil december 1948 til index 158, profitsummen til 21763. Også i de følgende år viser det samme billede sig. Efter oplysninger fra W.G. Hoffmann steg kapitalindkomsten fra 1950 til 1959 med gennemsnitlig 11,4\% (i tiden fra 1852 til 1913 - til sammenligning steg kapitalindkomsten 3,73\% pr. år), mens arbejdsindkomsten i det samme tidsrum kun steg $7 \%$ årligt i gennemsnit. Hvis man sætter 1950 lig 100, så stiger følgelig kapitalindkomsten indtil 1960 til en indexværdi på 294, mens arbejdsindkomsten kun stiger til en værdi på 184 .

Lønkvoten ved konstant beskæftigelsesstruktur forringedes tilsvarende fra 1950 til 1960 fra 58,6\% til 53,9\%, for de beskæftigede arbejdere i industri og håndværk faldt den fra 71,5\% til 67,8\% og opnår dermed - igen efter data fra W. G. Hoffmann - det laveste niveau siden $1850^{64}$ Også Uhlmanns og Hubers beregninger viser dette billede. Ifølge dem falder lønkvoten i 50 'erne fra $75,4 \%$ til $70,5 \%$, mens omvendt profitkvoten stiger fra $24,6 \%$ til $29,6 \%{ }^{65}$.

61. Jvf. dertil de sammenhænge, der blev udviklet i første del af denne artikel om stigningen i den beskæftigee arbejdsmasse ( $\Delta \mathrm{LN})$ og stigningen i netto- hhv. værdiproduktet $(\Delta \mathrm{Y})$; i: Kurasje nr. 12.

62. Wirtschaftskunde der BRD udg. Statistischen Bundesamt, Stuttgart og Köln 1955, s. 160.

63. Heininger, op.cit. s. 228.

64. W.G. Hoffmann op. cit., s. 91 og 98; Sachverständigenrat, Jahresgutachten 1967/68, ciff. 353.

65. RKW-Forschungsprojekt »Wirtschaftliche und soziale Aspekte des technischen Wandels in der Bundesrepublik Deutschland «, Bd 2:L. Uhlmann, G. Huber, Technischer und struktureller Wandel in der wachsenden Wirtschaft, Frankfurt a.M. 1971, s. 111, tabl. 42. 
Tabel 4:

Arbejdstid, løn, leveomkostninger 1949-1954.

\begin{tabular}{|c|c|c|c|c|}
\hline$\AA ̊ \AA r$ & $\begin{array}{l}\text { Ugentlig } \\
\text { arbejdstid }^{1}\end{array}$ & $\begin{array}{c}\text { Bruttotime- } \\
\text { løn } \\
1950=100^{2}\end{array}$ & $\begin{array}{l}\text { Bruttotime- } \\
\text { løn i DM }\end{array}$ & $\begin{array}{c}\text { Leveomkost- } \\
\text { ninger } \\
1950=100^{2}\end{array}$ \\
\hline $\begin{array}{l}1947 \\
1948 \\
1949 \\
\text { Marts } \\
\text { Juni } \\
\text { Sept. } \\
\text { Dec. } \\
1950 \\
\text { Marts } \\
\text { Juni } \\
\text { Sept. } \\
\text { Dec. } \\
1951 \\
\text { Marts } \\
\text { Juni } \\
\text { Sept. } \\
\text { Dec. } \\
1952 \\
\text { Febr. } \\
\text { Maj } \\
\text { August } \\
\text { Nov. } \\
1953 \\
\text { Maj } \\
\text { Nov. } \\
\text { 1954 } \\
\text { Maj } \\
\text { Nov. }\end{array}$ & $\begin{array}{r}39,7 \\
42,9 \\
47,2 \\
49,0 \\
48,5\end{array}$ & $\begin{array}{r}- \\
- \\
- \\
90,1 \\
93,3 \\
94,8 \\
95,5 \\
\\
96,5 \\
97,5 \\
100,6 \\
105,3 \\
109,0 \\
117,2 \\
118,0 \\
- \\
120,5 \\
122,3 \\
123,0 \\
125,0 \\
126,0 \\
129,4 \\
129,7 \\
133,0\end{array}$ & $\begin{array}{c}- \\
- \\
1,20\end{array}$ & $\begin{array}{c}- \\
- \\
- \\
108 \\
107 \\
105 \\
105 \\
\\
100 \\
99 \\
100 \\
101 \\
\\
106 \\
108 \\
109 \\
112 \\
\\
111 \\
109 \\
109 \\
110 \\
108 \\
107 \\
108 \\
110\end{array}$ \\
\hline
\end{tabular}

Kilde:

1. Wirtschaftskunde der BRD, udg. Statistisches Bundesamt; Stuttgart und Köln 1955, s. 400 (mandlige arbejdere).

2. Henry C. Wallich, Triebkräfte des deutschen Wiederaufstiegs, Frankfurt 1955, s. 78, 84, 92 , 98.

3. Karl Neelsen, Wirtschaftsgeschichte der BRD, Berlin 1971, s. 316.

At lønkvoten i vores figur 3 derimod stiger lidt, kan føres tilbage til, at lønomkostningerne er blevet sat i forhold til industriens nettoproduktionsvolumen, hertil kommer, at den ikke er inflationsrenset. 
På dette sted er det nødvendigt med nogle bemærkninger om beregningerne af lønomkostningsandelen af produktet i DIW's statistik og hos det $\varnothing$ konomiske råd; sådanne bemærkninger er især vigtige, når man vil analysere lønbevægelsen i 60'erne. »Styklønsomkostningerne « = løn- og gagesummen i forhold til den effektive nettoproduktionsvolumen hos Krengel o.a. er nemlig inflationært forfalsket gennem anvendelsen af nominallønninger, mens nettoproduktionsvolumen er beregnet som »reel« størrelse. ${ }^{65 a}$ Derved bliver naturligvis lønandelens stigningsrate af produktet uforholdsmæssig høj. (Denne indvending gælder ikke for de hidtidige anvendte data hos W. G. Hoffmann og dermed figuren 1 og 2!) Den stiger feks. fra 1950 til 1971 omkring 96,6\%), mens lønandelen af den totale omsætning, begge i nominelle størrelser, kun stiger omkring 28,9\% i det samme tidsrum (nogle beregninger af Krengel o.a.). Derved bliver to ting tydeligt: (1) at lønkvotens stigning sikkert har modvirket til den faldende kapitalrentabilitet; men at (2) dette er sket i meget ringere grad end det fremgår af kurve w's forløb. Fra denne kurve w kan der på ingen måde sluttes til de reelle fordelingsforhold, tværtimod bekræfter vores beregning vores tese om, at kapitalrentabiliteten i meget højere grad bliver bestemt af kapitalproduktivitetens udvikling og af den bagved skjulte forandring i kapitalens sammensætning end af lønudviklingen. (Se figur 4, s. 47).

\section{Heller ikke arbejderklassens kampe i 50'erne kunne ændre noget ved denne åben- bar forringelse af arbejdernes samfundsmæssige stilling i forhold til kapitalen. \\ Men nævneværdig i denne sammenhæng er dog, at fagforeningernes stra- tegi (slutningen af 40'erne/begyndelsen af 50'erne) om først at understøtte fuld-beskæftigelsespolitikken, dernæst at følge efter med lønbevægelsen, bi- drog aktiv til at hæve kapitalens akkumulationshurtighed.}

65a. Efter mundtlig oplysning fra DIW. Næsten lige så ubekymret går ved beregningen (eller i det mindste ved fremstillingen af beregningen) det $\varnothing$ konomiske råd frem, der ligeledes ikke anser det for nyttigt ved beregningen af lønomkostningsandelen af produktet at sige, at nominallønningerne bliver sat i forhold til deflationerede størrelser. Vi skal ikke her fortie, at vi selv har anvendt det $\varnothing$ konomiske råds beregninger i en artikel i »Handbuch I Politische Ökonomie Perspektiven des Kapitalismus « (Köln 1974) til beregning af kapitalrentabiliteten (jvf. også figur 4); den kritik som A. Blechschmid (i det samme bind) knytter til disse beregninger er dog tom, som vi her skal vise -. Man ser, at den borgerlige teoris strenge videnskabelighed også på overfladen begynde at lugte, når det drejer sig om at retfærdiggøre fordelingsforholdene og at levere materiale mod arbejdernes og fagforeningernes »umådelige store krav«. Selv om man tager hensyn til denne pengeforringelse, ændrer det intet afgørende ved resultatet. Der eksisterer ingen officiel statistik for reallønsudviklingen, således at man ikke slet og ret kan erstatte nominallønningerne, som vi var nødtvungne til at anvende i vores beregninger, med reallønningerne i beregningerne. For at beregne reallønsudviklingen må man anstille nogle komplicerede overvejelser. Således har vi kun modelagtigt gennemregnet, hvordan profitraten måtte have udviklet sig, hvis reallønningerne havde ligget 10\%, 20\%, 30\%, 40\%, $50 \%$ under nominallønningerne. Resultaterne er entydige: med en difference i 10-årsperioden fra 19601971 på 10\% mellem nominallønnen og reallønnen ville kapitalrenta biliteten være 0,39 i 1971, med en difference på $20 \%$ 0,43, med 30\% 0,46, med 40\% 0, 50, med 50\% 0,53 . Dette betyder, at ved at gab mellem reallønsudviklingen og nominallønsudviklingen på $50 \%$ må kapitalrentabiliteten være faldet lidt. Deroverfor er prisindexet for en 4-personerlønmodtagerhusholdnings levefod i den pågældende periode - efter den officielle statistik (det økonomiske råd) - steget med 35, 1\%. Hvis vi indfører en »deflateringsfaktor « modsvarende prisstigningen i levefoden, så får vi for tiåret fra 1960 til 1971 følgende bevægelse i kapitalrentabiliteten: 1960: 0,54; 1962: 0,48; 1964: 0,48; 1966: 0,45; 1967: 0,42; 1968: 0,46; 1969: 0,49; 1970: 0,47; 1971: 0,45. Vi ser, at også ved hensyntagen til reallønsudviklingen fremtræder faldet i kapitalrentabiliteten i de statistiske data omend - naturligvis - ikke så kraftig som på grundlag af de officielle inflationistisk forfalskede tal. 
Figur 4:

Udviklingen i kapitalrentabiliteten pi, kapitalproduktiviteten, profit pr. produktenhed og kapitalintensiteten (hele økonomien, ikke korrigeret for inflation!).

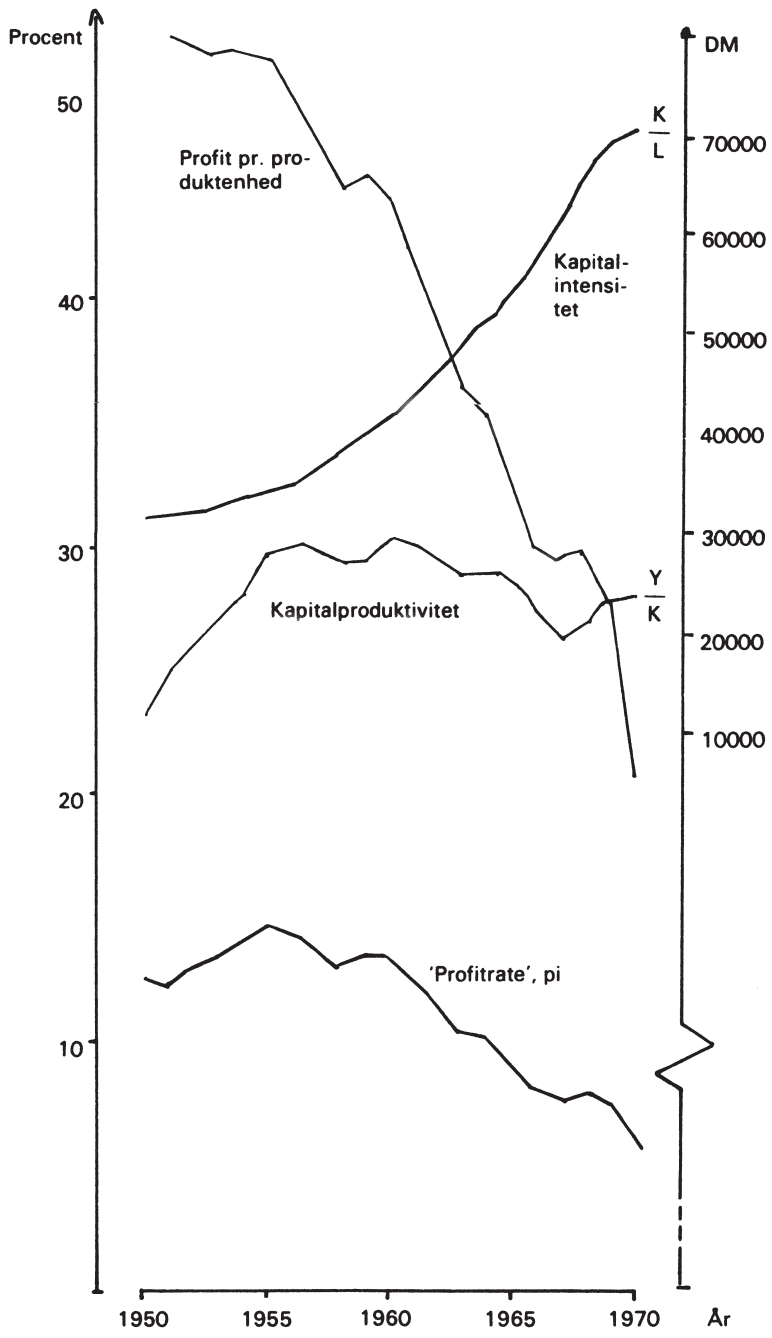

Kilde: SVG 1973 
Sammenfattende kan altså siges om udviklingen i fordelingsforholdet mellem profit og løn: For det første blev forholdet mellem lønkvote og profitkvote forringet. Det kommer til udtryk på den måde, at profitten steg meget hurtigere end lønningerne. For det andet stiger reallønningerne, ligesom det producerede værdiprodukt steg - som følge af indlemmelsen af yderligere arbejdskræfter i produktionsprocessen -. For det tredje stiger arbejdsproduktiviteten meget hurtigt i denne fase, i årligt gennemsnit hurtigere end reallønnen.

Før vi kan gå ind på kapitalrentabilitetens udvikling i denne fase, må udviklingstendenserne for den i produktionsmidler genstandgjorte kapital og arbejdets produktivkraft undersøges.

\subsubsection{Kapitalstock og arbejdsproduktivitet}

Ikke kun arbejdskræfter stod til rådighed for kapitalen i tilstrækkelig mængde, men også produktionskapaciteter var for hånden. For til at begynde med havde investeringerne under krigen, fremfor alt i afdeling I (produktionsmiddel-produktion), ført til betydelige kapacitetsudvidelser på basis af en dengang relativ højt udviklede teknologi ${ }^{66}$. Trods demontager og krigsskader var produktionskapaciteterne i de vigtige brancher ikke mindre end før krigen. For det meste var ubetydelige reparationsinvesteringer tilstrækkelige til igen at sætte gang $\mathrm{i}$ de bestående kapaciteter som funktionsduelig kapital. Således var relative små investeringer tilstrækkelige til at integrere store masser af udbytningsmulig arbejdskraft i produktionsprocessen. Enhver beskæftigelsestilvækst p.gr.a. den indtil 1957/58 stigende arbejdstid førte til forøgelse af de producerede værdiog merværdimasser, for så vidt de således beskæftigede arbejdere ydede produktivt og ikke uproduktivt arbejde ${ }^{67}$.

Den statslige $\varnothing$ konomiske politik, især skattebegunstigelserne, sørgede for, at en større del af de yderligere producerede merværdimasser blev akkumuleret. Således stiger investeringerne (beregnet i 1962 priser) alt i alt fra ca. 30 mia. DM til ca. 77 mia. DM, altså en stigning på 153\%. I disse tal er imidlertid end ikke angivet den samlede akkumulation, da den udvidede reproduktion jo ikke blot behøver yderligere produktionsmidler (bygninger og udstyr, hvis tilvækst der alene tages hensyn til i investeringerne), men også råstoffer og halvfabrikata og yderligere arbejdskræfter, der købes mod penge på arbejdsmarkedet. Den reproducerbare realkapital (værdisat til anskaffelsesprisen) stiger i den private sektor i alt fra 151 mia. DM i 1950 til 392 mia. DM i 1960, altså en stigning på 160\%, i industri og håndværk fra 74 mia. DM til 215 mia.

66. Jvf. R. Katzenstein, Die Investitionen - op.cit., s. 120ff, Heininger, op.cit., s. 48ff.; gennem denne proces forstærkedes naturligvis betydningen af afdeling I over for afdeling II, hvad som det allerede er fremstillet - udgør den materielle basis for den tyske expertafhængighed.

67. Ang. betydningen af det uproduktive arbejde jvf. neden for del 3.2.2. 
DM, altså en stigning på 190\%, hvorimod stigningsraten i den statslige sektor udgør netop $100 \%{ }^{68}$.

Den kapitaldannelse, der i stort omfang kom i gang i begyndelsen af 50'erne, måtte naturligvis gå frem med indførelsen af ny teknologi i produktionsprocessen. Sålænge der stod rigeligt med arbejdskræfter til rådighed og lønsatsen i sammenligning med andre kapitalistiske lande var lav og arbejdstiden kunne udvides, var forudsætningerne for en omvæltning af produktionsmetoderne ikke til stede. »De $\varnothing$ konomiske forudsætninger manglede endnu for anvendelsen af moderne teknik $\ll^{69}$.

Uden at kunne give en nærmere redegørelse for omfanget og retningen af de teknologiske innovationer i 50'erne, da der efter vor viden ikke foreligger nogen udførlige og holdbare undersøgelser og man kun er henvist til formodninger, så kan vi dog nævne de $\phi$ konomiske resultater.

Således stiger i 50'erne ikke blot investeringssummerne absolut, men investeringskvoten forøges også. Også i international sammenligning når den vesttyske investeringskvote et usædvanligt højt niveau. Men betegnende nok er i 50'erne reinvesteringernes andel af totalinvesteringerne relativ lav, - fremfor alt i sammenligning med 60'erne (jvf. tabel 4a). Deraf fremgår det, at kapitalstocken her må være blevet meget stærkt udvidet.

Tabel 4a:

Bruttoinvesteringer og nettoinvesteringer.

\begin{tabular}{l|c|c|c|c|c}
\hline$\AA$ År & $\begin{array}{c}\text { Bruttoin- } \\
\text { vesteringer }\end{array}$ & $\begin{array}{c}\text { Afskriv- } \\
\text { ninger }\end{array}$ & $\begin{array}{c}\text { Nettoinve- } \\
\text { steringer }\end{array}$ & $\begin{array}{c}\text { Nettoinve- } \\
\text { steringer i } \\
\text { procent af } \\
\text { bruttoinve- } \\
\text { steringer }\end{array}$ & $\begin{array}{c}\text { Afskrivni- } \\
\text { nger i procent } \\
\text { af national- } \\
\text { produktet }\end{array}$ \\
\hline 1950 & 18,74 & 8,32 & 10,42 & 55,6 & 8,5 \\
1955 & 42,63 & 14,05 & 28,58 & 67,0 & 7,6 \\
1960 & 68,96 & 24,27 & 44,69 & 64,8 & 8,5 \\
1962 & 93,77 & 33,48 & 60,29 & 64,3 & 9,3 \\
1964 & 113,49 & 44,17 & 72,32 & 63,7 & 9,8 \\
1966 & 126,31 & 50,68 & 75,63 & 59,9 & 10,3 \\
1968 & 124,78 & 57,40 & 67,38 & 54,0 & 10,6 \\
1970 & 181,08 & 74,78 & 106,30 & 58,7 & 10,9 \\
1972 & 215,55 & 93,61 & 121,94 & 56,6 & 11,3 \\
\hline
\end{tabular}

Kilde:

Sachverständigenrat, Jahresgutachten 1973, s. 212 og 216; egne beregninger.

68. Jvf. Wirtschaft und Statistik nr. 11 (1972), s. 621, tabel 5.

69. R. Katzenstein, op.cit., s. 135. 
I dette tidsrum stiger kapitalindsatsen pr. arbejdskraft kun ubetydelig i sammenligning med 60'erne, nemlig fra ca. $31.000 \mathrm{DM}$ af bruttoanlægsformuen pr. beskæftigede i 1950 til $41.400 \mathrm{DM}$ i $1960^{70}$, altså en stigning på ca. 33\%. Samtidig går arbejdsproduktiviteten, stejlt opad, nemlig ca. 75\%, og også kapitalproduktiviteten, der indicerer forholdet mellem levende og dødt arbejde, stiger indtil anden halvdel af 50'erne. Men sålænge arbejdsproduktiviteten vokser hurtigere end kapitalintensiteten (stigningen i arbejdsproduktiviteten er uafhængig af en tilvækst i kapitalintensiteten), kan kapitalrentabiliteten stige, når vel at mærke lønkvoten forbliver konstant eller falder. At dette var tilfældet, har vi fremstillet i det forangående afsnit.

Ud fra bevægelsen i arbejdsproduktiviteten og kapitalintensiteten slutter vi til karakteren af den teknologi, der er blevet indført i produktionsprocessen i løbet af 50'erne. Den kan ikke have været meget kapitalintensiv. Nye investeringer havde hverken hævet den tekniske eller den organiske sammensætning af kapitalen væsentligt. Den forbedrede udnyttelse af kapaciteterne, uddybningen af systemet af den samfundsmæssige arbejdsdeling, den langsomme indførelse af nye produktionsmetoder havde derfor ganske vist høje stigningsrater i arbejdsproduktiviteten til resultat, men kun en ubetydelig stigning i kapitalintensitet.

Dette forhold er i væsentlig grad - ved siden af det allerede beskrevne fald eller stagnation i lønkvoten - ansvarlig for, at kapitalrentabiliteten endnu i første halvdel af 50'erne stiger og derefter fra det høje niveau først langsomt falder.

Nøglen til forståelse af denne udvikling ligger for det første i forklaringen af den stagnerende eller endog faldende totaløkonomiske lønkvote, for det andet i forklaringen af de momenter, der har indflydelse på produktivitetsudviklingen.

Arbejdsproduktiviteten bliver statistisk målt som output (nettoproduktionsvolumen, nationalprodukt, nationalindkomst eller andre størrelser) i forhold til pr. arbejdsindsats (pr. erhvervsaktiv, pr. arbejder, pr. arbejdstime osv). Alt efter hvordan disse størrelser bliver sat i relation til hinanden fremkommer der forskellige resultater, der behøver adækvat interpretation ${ }^{71}$.

Men dette er ikke den eneste vanskelighed ved interpretationen af udviklingen i arbejdsproduktiviteten. Dertil kommer, at kendetegnene for udviklingen i arbejdsproduktiviteten er prisstørrelser. Derimod refererer udviklingen i arbejdets produktivkraft til den gennem forandringer i produktionsprocessen muliggjorte stigning i produktion af brugsværdier i en given tidsenhed. Når arbejdsproduktiviteten er steget, da er altså kun den producerede mængde af bestemte varer forøget pr. tidsenhed. Men i statistikken bliver denne mængde kun registreret som aggregerede prissummer. Selvom forandringerne i

70. Jvf. tabel 2.

71. Jvf. Klaus Grenzdörffer, Probleme der Produktivitätsmessung, i: Das Argument 73 (1972). 
prisniveauet bliver statistisk udskilt, kan talangivelsen for arbejdsproduktiviteten og dens udvikling ikke uden forbehold interpreteres som udtryk for arbejdets produktivkraft og dets stigning (jvf. også vor redegørelse i Kurasje 12). Derudover kan udviklingen i arbejdsproduktiviteten udtrykke de forskelligste processer. I den borgerlige økonomi har det i de forgangne år vundet indpas at anføre vækstraten i nationalproduktet, der forstås som aggregat af tilvæksten i arbejdsvolumen og arbejdsproduktivitet, tilbage til de forskellige faktorer. Det kommer der ikke blot udtrykkelige modsigelser udaf, men også eventyrlige resultater; for grundlaget forbliver produktionsfaktorteorien, der nu ved hjælp af forfinede matematiske beregninger bliver udvidet til 20,30, ja flere faktorer $^{72}$. Det hele fører til, at samlestørrelsen arbejdsproduktivitet bliver opdelt i forskellige komponenter - fra betydningen af arbejdskraftens kønssammensætning over forandringen i arbejdstiden til erkendelsesfremskridtet. Dermed vil man tilsyneladende opnå at kunne vurdere faktorerne i socialproduktets vækst i deres kvantitative virkning. I virkeligheden drejer det sig dog om unyttigt charlataneri, der foregøgler en nøjagtighed, der slet ikke kan opnås, fordi de teoretiske forudsætninger for de komplicerede beregninger er falske. Vi behøver altså ikke at opholde os længere med det. ${ }^{73}$

Alligevel består problemet, hvilke processer der indgår i talstørrelsen »stigning i arbejdsproduktivitet«. Vi må her gå ind på nogle af disse processer, der netop var relevante i Vesttyskland.

(1). Når - statistisk godtgjort - arbejdsproduktiviteten er forskellig i økonomiens brancher, så finder der alene en forhøjelse af den samlet økonomis arbejdsproduktivitet sted, hvis vægten af de relevante produktive brancher $\emptyset$ ges. I dette tilfælde beror stigningen i arbejdsproduktiviteten på den såkaldte »struktureffekt «. Dette moment har ikke spillet nogen afgørende rolle i 50'erne, selvom dets betydning har været større end i 60' erne $^{74}$.

(2). Stigningen i arbejdsproduktiviteten kan for den dels vedkommende, der ikke er kvantificerbar, bero på stigninger i arbejdets intensitet. Efter at arbejdskrafttilstrømningen ophørte og især som følge af arbejdstidsforkortelser i anden halvdel af 50'erne viste den mulighed sig at kompensere formindelsen af arbejdets extensive side gennem udvidelsen af den intensive størrelse. For det første blev dette muligt, da man ved den forkortede arbejdstid først fysisk kunne klare »udfyldningen af alle arbejdstidens porer«, og for det andet var dette nødvendigt for kapitalen ved den forkortede arbejdstid at få dækket omkostningerne ved den tradierede udbytningsrate. En intensivering af arbejdet

72. Jvf. f.eks. B.E.F. Denison, Why Growth Rates Differ, Washington D. C. (Brookings) 1967.

73. Et eksempel på sådanne beregninger bliver også hos Klaus Hüfner, Bildungsinvestitionen und Wirtschaftswachstum, Stuttgart 1970 citeret affirmativt. Deri bliver »vækstens determinanter « dechifreret med 25 faktorer og som 26. kategori indsættes endda »de ikke i betragtning taget determinanter «. (s. 58f).

74. Jvf. RKW-Forschungsprojekt, bd. 2 op.cit., s. 55ff. 
uden det politisk tryk, som der blev udøvet under fascismen, er kun muligt, hvis selve produktionsbetingelserne forandres, hvis altså arbejdsprocessen bliver så teknologisk forandret, at den tillader mere intensive arbejdsformer. Denne teknologiske forandring angår såvel produktionsmiddel-siden som arbejdsorganisationen, inklusive aflønningsformer. For produktionsmidlerne må være sådan udformet, at de kræver højere arbejdstempo, og arbejdsorganisationen må såvel indeholde et overvågningssystem som incitamenter for at arbejdere skal arbejde mere intensive, hurtigere, uden pauser. Set udfra produktionsmidlerne er det vigtigste middel indførelsen og udbredelsen af samlebåndet ${ }^{75}$.

Intensivering er altså en bagside af økonomiseringen med den konstante kapital: mest mulig rentabel udnyttelse af maskineriet på bekostning af »menneskematerialet«, der jo er den frie lønarbejders »materiale« og derfor angår det ikke eller kun lidt den enkelte kapitalist, hvis dette »materiale« bliver nedslidt før tiden. Arbejdsulykker, tidlig invaliditet osv. er vidnesbyrd derpå. Dog er der med den nye teknologi i reglen også forbundet en stigning i arbejdsintensiteten, idet en del af den målte produktivitetsstigning nødvendigvis skyldes den $\emptyset$ gede arbejdsintensitet, der statistisk ikke bliver angivet særskilt. Det betyder ikke andet end at forøgelsen eller opretholdelsen af merværdiraten p.gr.a. produktivitetsstigninger ikke kun skyldes den relative merværdiproduktion, altså stigning i arbejdets produktivkraft gennem forbedret maskineri etc., men også til en vis udstrækning skyldes den øgede arbejdsintensitet. Vi skal ikke her gå nærmere ind på, at der i selve arbejdsorganisationen og fremfor alt i incitamentsystemet med specifikke lønformer - arbejdsvurdering, mesterens rolle i produktionsprocessen, akkordjag, bonuslønninger, moderne metoder, der forudbestemmer arbejdstiden - f.eks. MTM eller Work Factor - næppe bliver en anden mulighed for den enkelte arbejder end at underkaste sig intensitetsstigningerne ${ }^{76}$.

(3). Stigninger i arbejdsproduktiviteten kan være resultatet af substitutionsprocesser for arbejde gennem den konstante, fremfor alt gennem den fixe kapital. Som følge af knaphed på arbejdskraft og som følge af arbejdskraftens pris kan der for den enkelte kapital opstå behov for at substituere arbejdskraft med kapital. Den kendsgerning, at der ifølge IFO-instituttets beregninger er blevet frisat alt i alt ca. 3 mio. arbejdere i perioden fra 1950 til $1960^{77}$, synes at tale for sådanne substituttionsprocesser. Imod det taler ganske vist den kun ubetydelige forøgelse af kapitalintensiteten. Deraf må man drage den slutning,

75. Jvf. Redaktionskollektiv Gewerkschaften, Zum Zusammenhang von Kapitalakkumulation, Veränderungen in den Formen der Profitproduktion und Rolle neuerer Entlohnungsmethoden, i: Probleme des Klassenkampfs nr. 4 og 5 (1972); Neelsen, Wirtschaftsgeschichte op.cit. s. 188.

76. Jvf. ibid. og R. Schmiede, Entwicklungstendenzen und Widersprüche der Leistungsentlohnung, i: Gewerkschaften und Klassenkampf, Kritisches Jahrbuch 74, Frankfurt a.M. 1974.

77. RKW-Forschungsprojekt, bd. 1: Sieben Berichte, Frankfurt a.M. 1970, s. 102ff. 
at for det første kunne de frisatte arbejdere p.gr.a. det høje akkumulationstempo uden besvær igen integreres i produktionsprocessen, at for det andet var de nye arbejdspladser kun lidt mere kapitalintensive end de gamle og at for det tredje var stigningen i kapitalintensiteten på ca. en tredjedel alligevel nok, fordi man til fremstillingen af et nettoprodukt på en bestemt størrelse i 1960 kunne klare sig med knapt 8\% af arbejdskræfterne fra 1950. Dette fænomen kan kun forklares, hvis man går ud fra, at det »tekniske fremskridt « i 50'erne ikke har været så kapitalintensivt som i årene derefter.

(4). Dermed kan vi gå over til den fjerde komponent, der forårsager produktivitetsstigningen. Gennem produktionsudvidelse, gennem indlemmelsen af bestemte produktioner i arbejdsdelingssystemet kan der statistisk registreres produktivitetsfremskridt, som hverken beror på substitutions- eller på struktureffekter eller på en forhøjelse af arbejdsintensiteten. Den tilstrækkelige disposition af råstoffer som jern og stål eller den regelmæssige forsyning med elektricitet, vand og kul kunne udøve store, produktivitetsstigende effekter. For den derigennem muliggjorte kontinuitet i produktionen, stigningen af kapitalens cirkulation bevirker en stigning i output pr. arbejder. Netop i begyndelsen af 50 'erne har denne komponent i produktivitetsudviklingen spillet en helt afg $\varnothing$ rende rolle ${ }^{78}$. Ved eksemplet med investeringshjælpeloven har vi også omtalt, at der gennem den statslige politik til underst $\varnothing t t e l s e$ af de grene, hvis produkter set udfra brugsværdisiden var særlige vigtige for akkumulationen, er blevet opnået betydelige effekter også med hensyn til stigning i produktiviteten uden kapitalintensivering.

Disse enkelte komponenter er ikke lige virksomme i enhver periode. Især det sidstnævnte moment spiller kun en betydelig rolle, når produktionen udvikler sig fra et lavt niveau, skønt kapaciteter og arbejdskræfte er for hånden, for egentlig at nå et højere niveau for produktionen. Derfor er stigningsraterne for produktiviteten, når man betragter dens cykliske bevægelse, på det højeste i opsvinget umiddelbart efter krisen. I senere faser, hvor denne »spænding « (Janossy) ikke længere er virksom, kan stigninger i arbejdsproduktiviten kun opnås gennem tilsvarende kapitalindskud, der øger kapitalintensiteten ${ }^{79}$.

Som vi allerede har set udfra arbejdsproduktivitetens og kapitalintensitetens empiriske bevægelse, har det også for Vesttyskland vist sig, at den situation er usædvanlig, hvor produktivkraftstigninger i flere år ligger over kapitalintensitetens tilvækstrate. Stigningsraterne for kurven K/L og Y / L i vor figur 3 gaber fra hinanden siden midten af 50'erne.

Sammenfattende kan altså siges:

78. Sachverständigenrat, Jahrgutachten $69 / 70$, cif. 53.

79. Dette bliver bekræftet af RKW-Forschungsprojekt (Berichtsband, op.cit.): »Personaleudgiftsbesparelserne var på alle måder bundet til indsættelsen af maskinelle konstruktioner til høj værdi. Derved er de absolutte udgifter til faktoren kapital steget i de relevante tilfælde med mere end tre fjerdedel.« (s. 120). 
Det høje niveau for og stigning i kapitalvaloriseringen i 50'erne kan forklares ved

- arbejderklassens lave konsumtionsniveau og den lave lønandel af nettoproduktionsvolumen (høj merværdirate);

- de produktivitetsstigninger der var uafhængige af kapitalintensiveringen; de skete, uden at der havde fundet en større udvidelse af kapitalstocken pr. erhvervsaktive sted;

- den lange arbejdstid og den hurtige indlemmelse af yderligere produktive arbejdere i produktionsprocessen.

3.2.3. Den fulde beskaftigelse som skranke for profitproduktionen og kapitalakkumulationen

Det fremskyndede opsving uden en væsentlig forandring af kapitalintensiteten førte til en absorption af de tilrådighed stående arbejdskræfter i produktionsprocessen. Havde akkumulationsprocessen været mere »kapitalintensiv«, så var opløsningen af reservearmeen af arbejdsløse forløbet langsommere. Men p.gr.a. knapheden på arbejdskræfter siden anden halvdel af 50'erne har muligheden for merværdiproduktion gennem forøgelse af beskæftigelsen uden omfattende produktionsteknologiske forandringer nået en grænse.

Tilførslen af arbejdskræfter i 50'erne er sammensat af følgende komponenter:

(a) Opløsning af reservearmeen af arbejdsløse,

(b) tilvandring af flygtninge,

(c) forøgelse af beskæftigelseskvoten, især gennem udvidelsen af kvindearbejdet

(d) naturlig befolkningstilvækst

(e) genindsættelse af de arbejdskræfter, der er blevet frisat ved den tekniske udvikling

(f) forvandling af hidtidige »selvstændige« til lønarbejdere som følge af koncentrationen og centralisationen

(g) forøgelse af den ugentlige arbejdstid

(h) tilførsel af udenlandske arbejdskræfter.

Per saldo virkede disse komponenter positivt på arbejdsvolumen, dvs. de samlet ydede arbejdstimer indenfor et år. Fra 1957 aftog arbejdsvolumen dog:

\section{Tabel 5:}

Stigning i arbejdsvolumen fra 1951 til 1960.

\begin{tabular}{cccccccccc}
1951 & 1952 & 1953 & 1954 & 1955 & 1956 & 1957 & 1958 & 1959 & 1960 \\
\hline 2,0 & 1,3 & 2,1 & 2,2 & 3,0 & 1,6 & $-1,4$ & $-1,1$ & $-0,6$ & 1,2 \\
\hline
\end{tabular}

Kilde:

$R K W$, Wirtschaftliche und soziale Aspekte des technischen Wandels in der Bundesrepublik Deutschland, Sieben Berichte, Erster Band, Frankfurt/M, 1970, s. 23. 
I disse tal kommer følgende proces til udtryk:

Arbejdsløsheden bliver reduceret fra 10,3\% i 1950 til 1,3\% i 1960. Flygtningetilstrømningen udgør i dette tidsrum 2,63 mio. mennesker i alle aldersklasser. Beskæftigelseskvoten, dvs. antallet af beskæftigede i forhold til befolkningen forøges fra $46 \%$ til $48 \%$, den naturlige befolkningstilvækst udgør i den tilsvarende periode mellem 4 og 6 personer af 1000 indbyggere, hvorved man dog må tage i betragtning, at virkningen af den naturlige befolkningstilvækst på arbejdsvolumen alt i alt var negativ som følge af krigstabene. På grund af teknisk forandring blev alt i alt ca. 2 mio. arbejdskræfter frisat, og stod således tilrådighed som nye arbejdskræfter. Antallet af »afhængige « beskæftigede af det samlet antal erhvervsaktive tog til i den nævnte periode fra $69 \%$ til 77\%; tilsvarende bliver produktionsprocessen tilført tidligere $»$ selvstændige existenser « som lønarbejdere.

Udenlandske arbejdskræfter bliver først i nævneværdigt omfang ansat i begyndelsen af 60'erne, hvilket vil sige, at vi ikke behøver at tage hensyn til dem her. Arbejdstiden pr. uge stiger kun indtil 1955/56 og aftager derefter stadig p.gr.a. overenskomstmæssige gennemførte arbejdstidsforkortelser ${ }^{80}$

Alt i alt virker disse faktorer således, at »beskæftigelsesskranken $\ll^{81}$ bliver tydelig i begyndelsen af anden halvdel af 50'erne. Med stagnationen og nedgangen i den produktivt anvendte arbejdstid stagnerer først og fremmest værdidannelsesprocessen. Dermed var heller ikke længere akkumulationen af kapital mulig ved indsættelse af yderligere arbejdskræfter i produktionsprocessen uden forandring af det tekniske grundlag.

Skal under disse betingelser den akkumulerede del af profitten udvides, så kan det kun ske under to forudsætninger: Enten indskrænkes kapitalistklassens konsumtion og/eller arbejderklassens eller kapitalen går over til at ændre produktionsbetingelserne for at $\emptyset \mathrm{ge}$ arbejdsproduktiviteten. Reproduktionsomkostningerne for arbejdskraften kan dermed sænkes uden at reallønnen behøver at nedsættes.

Den første metode er så godt som udelukket i den udviklingsfase af kapitalismen, som vi her betragter. Den skærpede konkurrence mellem de enkelte kapitalister om den knappe vare arbejdskraft muliggør netop lønstigninger, der atter begrænser udvidelsen i den akkumulationsduelige merværdi. Således er det ikke kun den stagnerende og endog nedadgående arbejdsvolumen, der sætter grænser for værdi- og merværdiproduktionen ved givet teknologisk niveau; også lønstigninger har en tilsvarende virkning: ved givet teknologisk niveau, dvs. uden stigning i arbejdsproduktiviteten, forringer de merværdien, trykker kapitalrentabiliteten ned og forringer akkumulationsfonden. I denne situation

80. Jvf. Neelsen, op.cit., s. 171ff, Osterland m.fl., Materialien zur Lebens- und Arbeitssituation der Industriearbeiter in der BRD, Frankfurt a.M. 1973, tabel 61 med bilag.

81. W. Vogt, Makroökonomische Bestimmungsgründe des Wirtschaftlichen Wachstums in der Bundesrepublik Deutschland von 1950 bis 1960, Tübingen 1964, s. 158. 
er det nødvendigt teknologisk at forandre den kapitalistiske produktionsproces gennem stigende indsats af maskiner, gennem nye produktionsmetoder, ændret arbejdsorganisation, automatisering, kemisering, gennem indførelse af elektronik osv. Selvom disse processer påtvinges den enkelte kapitalist gennem jagten efter extraprofitter - enhver kapitalist må ved knaphed på arbejdskræfter have et teknisk forspring for konkurrenten for at forøge sin markedsandel, dvs. sin profit - , så resulterer de dog $\mathrm{i}$ almindelighed $\mathrm{i}$, at de produkter, der indgår i arbejderklassens konsumtionsfond, bliver billigere ${ }^{82}$. Dermed kan indtræde en stigning i merværdiraten, der er større, jo større diskrepansen er mellem lønstigningerne og produktivitetstilvæksten.

Af tabel 9 (i del 3.3.2) fremgår det, at realløntilvæksten i 50'erne er ringere end stigningen i arbejdsproduktiviteten. Først da arbejdskrafttilstrømningen blev ringere og først rigtigt da arbejdstiden blev nedsat, fik produktivitets stigningen en ny karakter. Den terroristisk fremtvungne forøgelse af den tyske arbejderklasses udbytningsrate - som det ovenfor er beskrevet - truede nu som følge af kapitalens akkumulationsbevægelse med at gå tilbage på den måde, at både arbejdstiden og dermed også merarbejdstiden blev reduceret og fremfor alt ved at lønningerne i anden halvdel af 50'erne kunne forøges stærkt.

Den vesttyske kapitalismes ideologi i 50'erne om »konsumsamfundet«, »velstand for alle«, »folkekapitalisme « osv. havde en funktionel og en helt og holdent disfunktionel side for akkumulationsbevægelse. Funktionelt var det i hvert fald, at denne ideologi virkede stabiliserende på herredømmet; men det var disfunktionelt, at arbejderklassen ved at henholde sig til denne ideologis indhold kunne hæve sit konsumtionsniveau gennem fagforeningsmæssige kampe, først og fremmest for at indhente det forgangne årtis forsømmelser (»ædebølge«, »tøjbølge«, »rejsebølge« osv.), men også fordi der opstod helt nye behov og behovsstrukturer, der er blevet frembragt af kapitalismen selv i dens akkumulationsproces. Således skriver også Neelsen: »Samtidig udvidedes arbejderklassens livsnødvendige behov, hvad (for de arbejdende) resulterede i stigende arbejdsintensitet såvel som i den almene videreudvikling af produktivkræfterne, der medførte nye samfundsmæssige behov ${ }^{83}$.

Hvis et nyt, højere konsumtionsniveau kan opretholdes i længere tid, altså over flere cykler, og hvis det også modsvares af de nye »forhøjede « behovsstrukturer, så har dette nye konsumtionsniveau ikke kun konsekvenser for lønudviklingen, men for arbejdskraftens reproduktionsomkostninger, $d v$ s. $i$ sidste instans for dens vardi.

Akkurat som fascismen eftertrykkeligt nedsatte værdien af varen arbejdskraft, idet den reducerede arbejdskraftens reproduktionsniveau med »kanoner i stedet for smør«, ligeså bliver værdien og ikke kun prisen på arbejdskraften berørt, når arbejdskraftens reproduktionsniveau virkeligt og eftertrykkeligt bli-

82. Denne »billiggørelse « refererer naturligvis kun til værdistørrelsen!

83. Neelsen, op.cit., s. 194. 
ver forbedret. Forskellen mellem en prisændring på arbejdskraften i løbet af en cyklus og værdiændringen består $\mathrm{i}$, at det nye reproduktionsniveau, udtrykt $i$ vardier, selv bliver til et gravitationscentrum, omkring hvilket prisen på varen arbejdskraft svinger. Det marxske udsagn, at arbejdskraftens værdi indeholder et moralsk og historisk moment, har vist sig ganske tydeligt i sin økonomiske virulens i BRD's historie. Hvis ikke man betragter værdiændringerne af de enkelte elementer i de varer, der indgår i reproduktionen af arbejderklassen, er det ikke muligt ud fra denne udvikling at slutte, at arbejdskraftens værdi er blevet forøget p.gr.a. disse processer. En sådan slutning ville i det mindste være forhastet. Hvad der er blevet ændret i retning af en forbedring, er arbejderklassens levestandard. Men selvom værdien af de varer, der indgår i reproduktionen, som følge af de stærke produktivitetsstigninger, ikke skulle have været højere end værdien af de varer, der udgjorde det lavere under fascismen fremtvungne konsumtionsniveau, så betyder dette dog en begrænsning for arbejdskraftens værdinedsættelse, og derfor for merværdiens udvidelse.

Tilsvarende kan lønningerne i krisen ikke sænkes så meget, at de ikke længere sikrer det engang historisk opnået reproduktionsniveau, uden at arbejderne og deres organisationer gør modstand ${ }^{84}$.

Således bliver de forudsætninger, der under fascismen blev sat for den høje merværdirate, lidt efter lidt opløst. Kapitalen bliver derfor i løbet af 50'erne mere og mere henvist til dens genuine metoder for merværdiratens stigning gennem stigning i arbejdets produktivkraft, dvs. billiggørelse af reproduktionsomkostningernes elementer og intensivering af arbejdet gennem omorganisering af arbejdsprocessen. Men da produktivitetsstigninger ikke længere i den grad var mulige som endnu i begyndelsen af 50'erne gennem blotte forhøjelser i udnyttelsesgraden af kapaciteterne, gennem uddybning af systemet for arbejdsdeling, gennem masseproduktion (economies of scale) osv., stiger kapitaludgiften til produktivitetsstigning nu enormt.

Der begynder følgelig i slutningen af 50'erne en ny fase af kapitalakkumulationen i Vesttyskland. Selve overgangen kunne forløbe gnidningsløs, fordi de nye produktionsbetingelser kunne indføres relativt let p.gr.a. kapitalrentabilitetens meget høje niveau og - således kan vi slutte - profitratens meget høje niveau. Der var kun krisefremtrædelser i enkelte brancher og sektorer - således indenfor minedrift og landbrug -, men de spillede ingen rolle, da de arbejdskræfter, der blev frisat i krisen, relativt let kunne anbringes i andre områder og profitmassen og profitraten var stor nok i produktionen til at subventionere de enkeltkapitalier, der var kommet i krise, eller at overtage dem i centralisationsprocesserne. Desuden expanderede det kapitalistiske verdensmarked og tilbød således den vesttyske kapital et stadig større realiseringsområde for dens varer.

84. Jvf. dertil især E. Mandel, der i 5. kapitel i sin bog Der Spätkapitalismus (Frankfurt a.M. 1972) udvikler denne sammenhæng. 


\subsection{Profitrate og kapitalakkumulation i Vesttyskland i 60'erne.}

\subsubsection{Forandring i kapitalvaloriseringstendensen i 60'erne.}

I de tidligere dele er det blevet vist, hvilke $\varnothing$ konomiske og politiske forhold der muliggjorde den hurtige kapitalakkumulation i 50'erne i BRD. Set fra den $\varnothing$ konomiske side var det især den vesttyske arbejders lave reallønsniveau, den lave lønandel af industriens nettoproduktionsvolumen og af nationalindkomsten i den samlede $\varnothing$ konomi, den lange arbejdstid, de tilrådighed stående arbejdere og produktionsstigningerne (uden tilsvarende kapitalintensivering), der muliggjorde et højt niveau for kapitalvaloriseringen og en krisefri udvikling af den vesttyske kapitalisme indtil 60'erne. Men disse overordentlige gunstige betingelser for kapitalakkumulationen forsvinder efterhånden i slutningen af 50 'erne. Der fremtræder derfor mere og mere andre tendenser. Før vi i detalje går ind på årsagerne til de ændrede akkumulations- og valoriseringsbetingelser i 60'erne, vil vi først sammefatte nogle globale tendenser.

I løbet af kapitalakkumulationen i sidste halvdel af 50'erne viser der sig allerede en knaphed på arbejdskræfter, der blev til et bestemmende moment $\mathrm{i}$ 60 'erne. Ikke blot steg de vesttyske arbejders reallønninger, men lønandelen af nettoproduktionsvolumen steg også. Denne stigning i lønandelen til ugunst for profitandelen er især iøjnefaldende for første halvdel af 60'erne (og igen for 70'erne). Hvorvidt man nu derfra også kan slutte til et fald i merværdiraten, skal undersøges nedenfor.

Et yderligere vigtigt kendetegn for 60'erne er den enorme stigning i kapitalintensiteten. Efter vore beregninger steg kapitalintensiteten i 60'erne hurtigere end arbejdsproduktiviteten. Stiger kapitalintensiteten i 50'erne med $28 \%$ og arbejdsproduktiviteten med $57 \%$, så stiger kapitalintensiteten i 60'erne derimod med 74\% og arbejdsproduktiviteten med 62\%. (Begge størrelser refererer til industriområdet). Til grund for denne tendens synes at ligge følgende årsager: Var det endnu muligt i 50'erne at $\varnothing \mathrm{ge}$ arbejdsproduktiviteten gennem strukturændringer industrigrene imellem gennem en stigende udnyttelsesgrad af kapitalstocken, gennem tiltagende masseproduktion og også gennem arbejdsintensivering, så er disse muligheder i overvejende grad udtømt i 60' erne $^{85}$.

En stigende masse af fix kapital, teknologiske innovationer, såvel som en stigende kapitalindsats pr. arbejdskraft bliver nu nødvendig for igen at $\emptyset$ ge arbejdsproduktiviteten. Denne stigende kapitalintensivering af produktionen og substitutionen af arbejdskraft med maskineri bevirker ganske vist produktivitetsstigninger, men kapitaludgiften pr. arbejder stiger hurtigere end produktionsoutputtet pr. arbejder, altså hurtigere end arbejdsproduktiviteten. Dette giver os atter - i overensstemmelse med vore tidligere overvejelser - en henvisning til, hvordan kapitalens organiske sammensætning og forholdet mellem

85. Jvf. dertil RKW-Forschungsprojekt, bd. 1, op.cit., s. 38. 
dødt og levende arbejde (c/v+m) har udviklet sig; dette forhold kan indiceres gennem kapitalproduktivitetens modværdi, kapitalkoefficienterne (K/Y). Efter disse indikatorer måtte såvel, kapitalens organiske sammensætning som forholdet mellem dødt og levende arbejde være steget og profitraten faldet.

Denne udviklingstendens i indikatorerne for kapitalvaloriseringen kan også uddrages af vores beregninger (jvf. tabel 2) og af vores figur (figur 3): Kapitalintensiteten $(\mathrm{K})$ stiger hurtigere i 60'erne end arbejdsproduktiviteten $\mathrm{Y} / \mathrm{L}$. Tilsvarende falder også kapitalproduktiviteten $\mathrm{Y} / \mathrm{K}$ - vores indirekte udtryk for forholdet mellem levende arbejde og dødt arbejde $(v+m) / c$. Faldet i kapitalproduktiviteten er den langsigtet bestemmende tendens, der allerede aftegner sig siden midten af 50'erne og som efter vores interpretation skyldes faldet i kapitalvaloriseringen. Derudover stiger lønandelen af nettoproduktionsvolumen i 60'erne ikke i den grad, som det vises i figuren (vi har netop refereret til den inflationære forfalskning). Derigennem bliver faldet i kapitalrentabiliteten - og, som vi kan slutte, faldet i profitraten - yderligere forstærket.

Men hvorvidt arbejderne virkelig - som man ved første blik ville slutte kunne erhverve sig en stigende andel af produktivitetsstigningerne og følgelig få merværdiraten til at stagnere eller endog falde, skal undersøges yderligere.

De fremstillede akkumulationstendenser for kapitalen i BRD bliver ved en international sammenligning endnu tydeligere, især hvis vi konfronterer niveau og udviklingstendens for kapitalintensitet, arbejdsproduktivitet, kapitalproduktivitet og lønudvikling med USA's.

Ved denne sammenligning begrænser vi os til den forarbejdede industris område. I den forbindelse vil vi ikke så meget undersøge den absolutte niveau-forskel mellem kapitalvaloriseringens enkelte komponenter, men deres forandring over et tidsforløb; vi vil heller ikke undersøge årsagerne til niveau-forskellen i de enkelte komponenter. Dette er delvis allerede foretaget gennem andre arbejder ${ }^{86}$. Vi interesserer os her kun for vækstraterne, altså for de tendensmæssige forandringer. Holder man sig de gennemsnitlige årlige vækstrater i arbejdsproduktiviteten for $\emptyset j$ je (jvf. tabel 6), så viser sig følgende tendens:

Vækstraterne i arbejdsproduktiviteten er i BRD såvel i 50'erne som i 60'erne næsten dobbelt så høje som i USA. Deraf kan man slutte, at niveau-forskellen i arbejdsproduktiviteten er formindsket. I overensstemmelse hermed er den såkaldte »teknologiske kløft « mellem BRD og USA blevet formindsket i de to sidste årtier. Ifølge undersøgelser af H. Majer ${ }^{87}$ passer dette især for den kemiske-, metallurgiske-, kunststof-, gummi- og elektroniske industri.

86. Jvf. K. Busch, Die multinationalen Konzernen, Frankfurt a.M. 1974, der begrunder niveauforskellen mellem USA og Vesttyskland med forskellen i teknologi, arbejdskraftens kvalifikation og markedernes størrelse (masseproduktion).

87. H. Majer, Die »Technologische Lücke« zwischen der Bundesrepublik Deutschland und den Vereinigten Staaten von Amerika, Tübingen 1973. 
Disse høje vækstrater i arbejdsproduktiviteten er imidlertid i BRD blevet købt med en enorm kapitalintensivering. Vækstraterne i kapitalintensiteten er ganske vist i 50'erne i BRD og i USA næsten ens (4\% årligt), men i 60'erne steg vækstraterne i BRD med et årligt gennemsnit på 6,9\%. I USA derimod lå de kun på $1 \%$.

\section{Tabel 6:}

Gennemsnitlig årlig vækstrate for arbejdsproduktivitet, kapitalproduktivitet og kapitalintensitet $i$ de industrielle fremstillingsvirksomheder $i$ Vesttyskland og USA 1950/70 (priser og købekraft i US-dollar fra 1962).

\begin{tabular}{l|c|c|c|c|c|c}
\hline & \multicolumn{2}{|c|}{$\begin{array}{c}\text { Arbejdsproduk- } \\
\text { tivitet (Y/L) }\end{array}$} & \multicolumn{2}{c|}{$\begin{array}{c}\text { Kapitalproduk- } \\
\text { tivitet (Y/K) }\end{array}$} & \multicolumn{2}{c}{$\begin{array}{c}\text { Kapitalintensitet } \\
(\mathrm{K} / \mathrm{L})\end{array}$} \\
\hline & $50 / 60$ & $60 / 70$ & $50 / 60$ & $60 / 70$ & $50 / 60$ & $60 / 70$ \\
\hline BRD & 5,7 & 5,7 & 1,7 & $-1,2$ & 3,9 & 6,9 \\
\hline USA & 2,2 & 2,9 & $-1,7$ & 2,0 & 4,0 & 1,0 \\
\hline
\end{tabular}

Kilde:

H. Majer, Die »Technologische Lücke« zwischen der Bundesrepublik und den Vereinigten Staaten von Amerika, Tübingen 1973; egne beregninger.

Deraf fremgår det, at US-kapitalen har opnået en stigning i arbejdsproduktiviteten $(2,9 \%)$ med en ringere vækstrate for kapitaludgiften pr. arbejder $(1,0 \%)$. BRD-kapitalen opnåede ganske vist en meget højere produktivitetsstigning

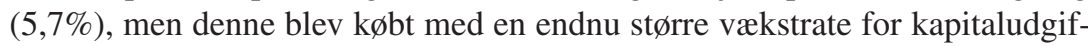
ten pr. arbejder $(6,9 \%)$.

Tilsvarende viser der sig også en ganske modgående bevægelse i udviklingen af kapitalproduktiviteten i de to lande. I USA falder kapitalproduktiviteten i 50'erne, men stiger i 60'erne. Omvendt i BRD: Her stiger kapitalproduktiviteten indtil anden halvdel af 50'erne, men falder i 60'erne. Disse udviklingstendenser er også påviselige i de vigtigste industrigrene.

Hvis man vil sammenligne udviklingsretningen for kapitalvaloriseringen i de to lande er det imidlertid nødvendigt at tage forandringen i lønandelen af nettoproduktet i de to lande $\mathrm{i}$ betragtning. For BRD har vi allerede foretaget dette. For USA kan det fastslås, at lønkvoten ganske vist stiger totalsamfundsmæssigt i 60'erne, ja i slutningen af 60'erne stiger den endog kraftigt (efter vore beregninger fra 70,7 (1960) til 71,6 (1968) for 1971 at accelerere til $76,4^{88}$; men her må man tage hensyn til de samme indvendinger, som vi gjorde

88. Egne beregninger efter OECD, National Accounts u.s. og u.å. (1970). 
gældende ved betragtning af lønkvoten i BRD (i 3.3.2.). Bliver vor analyse ganske vist stadig problematisk med hensyn til lønkvoten, så kan man dog p.gr.a. den store kapitalintensivering og p.gr.a. den faldende kapitalproduktivitet i BRD slutte, at kapitalvaloriseringen i BRD i 60'erne er blevet forringet hurtigere end i USA ${ }^{89}$ ), skønt kapitalrentabilitetens niveau i USA sandsynligvis stadigvæk ligger lavere end i BRD.

Denne forskel, der er i forandringen af valoriseringsbetingelserne for kapitalen i de to lande, lader imidlertid formode, at kapitalrentabilitetsniveauet $\mathrm{i}$ de to lande også har tilnærmet sig hinanden. Dette gælder ganske vist kun for 60'erne. For 50'erne kan man derimod konstatere - som det fremgår af Maddisons og andres unders $\varnothing$ gelser - , at forskellen i kapitalrentabiliteten endnu var meget stor. Efter disse beregninger ${ }^{90}$ var forholdet mellem bruttoprofit og fixe kapital (inklusive lagerbeholdning) i USA i gennemsnit fra 1950 til 1960 ca. $18 \%$, mens kapitalvaloriseringen efter denne beregning i det samme tidsrum for BRD-kapitalen var på 27,5\%.

Vi vil ikke udvide disse beregninger af kapitalvaloriseringens niveau til 60 'erne og 70'erne; for det drejer sig først og fremmest om at påvise forskydninger i tendensen i BRD-kapitalrentabiliteten over for kapitalens rentabilitet i USA ved hjælp af vore komponenter for kapitalvalorisering. Gennem denne internationale sammenligning ville vi endnu engang tydeliggøre forringelsen af valoriseringsbetingelserne for BRD-kapitalen i 60'erne overfor 50'erne og tydeliggøre årsagen til faldet i kapitalvaloriseringens rate - den enorme kapitalakkumulation og kapitalintensivering ${ }^{91}$.

\subsubsection{Profit og lфn i 60'erne}

Denne hurtige kapitalakkumulation i BRD havde - som allerede vist - til følge, at skranken for den absolutte masse af exploitabel arbejdskraft gjorde sig gældende fra omkring midten af 50'erne. Denne skranke for akkumulationen består også i 60'erne, selvom kapitalen gennem indlemmelse af udenlandske arbejdere (»gæstearbejdere «) og beskæftigelse af kvinder i produktionsprocessen atter forsøger at forskyde den: Antallet af udenlandske arbejdere stiger fra

89. Dette kan også, udover vekselkursforskydninger, være en grund til den forstærkede kapitaludstrømning i USA i 1970'erne. Jvf. dertil vores sidste del.

90. A. Maddison, Economic Growth in the West, op.cit., s. 53.

91. For at kunne forklare ophævelsen af niveauforskellene og de mekanismer, der bevirker den, er der flere ansatser: for det første fra den neo-klassiske vækstforskning (Dennison, op.cit.), for det andet Ch. P. Kindleberger (Europe's Postwar Growth, The Role of Labour Supply, Harvard University Press, Cambridge (Mass) 1967, der går ud fra den lave lønrate og overskudsarbejderbefolkningen i Vesteuropa. Videre må her nævnes A. Maddison (op.cit.) der forklarer Vesteuropas efterkrigsvækst ud fra den rolle som den statslige efterspørgsel spillede. Jvf. marxistiske interpretationer E. Mandel, Die EWG und die Konkurrenz USA-Europa, Frankfurt a.M. 1968 og Klaus Busch op.cit., der dog ikke går ud fra en akkumulationsteoretisk ansats. 
329.000 (1960) til 1,2 mio. (1965) og til 1,9 mio. (1970)92. Antallet af kvindelige erhvervsaktive, der er beskæftiget i de "producerende erhverv «, stiger i tidsrummet fra 1957 til 1970 fra 2,8 mio. til 3,2 mio. ${ }^{93}$ Alligevel stagnerer (opgivet totalsamfundsmæssigt) arbejdsvolumen, antallet af ydet arbejdstimer falder endog fra 55658 mio. (1960) til 54200 mio. (1970) (jvf. også tabel 7). Ser man bort fra de i første del (Kurasje 12) anførte begrænsninger i indikatoren »arbejdstid « for værdidannelsen, så kan man udfra det absolutte fald i de forbrugte arbejdskvanta slutte, at værdidannelsesprocessen ikke længere kan udvides i 60'erne, selvom produktionen af brugsværdier stadig forøges gennem forhøjelsen af arbejdets produktivkraft ${ }^{94}$.

\section{Tabel 7:}

\section{Vækstraten i arbejdsvolumen i 1960'erne.}

\begin{tabular}{ccccccccccc}
\hline 1960 & 1961 & 1962 & 1963 & 1964 & 1965 & 1966 & 1967 & 1968 & 1969 & 1970 \\
\hline 1,2 & 0,3 & $-0,4$ & $-0,7$ & 0,4 & $-0,3$ & $-1,2$ & $-3,3$ & 0,8 & 1,5 & 1,1 \\
\hline
\end{tabular}

Kilde:

Statistisches Jahrbuch 1971, RKW-Forschungsprojekt, op. cit.

Produktionen af yderligere merværdi må dermed også (som allerede ovenfor vist) støde på en grænse, for så vidt den sker gennem den absolutte udvidelse af arbejdstiden eller gennem antallet af exploitable produktive arbejdere. Denne grænse bliver især i slutningen af 50'erne/i begyndelsen af 60'erne i den grad snævrere, idet arbejderne og deres organisationer i dette tidsrum p.gr.a. knapheden på varen arbejdskraft opnår en stærkere position i kampen om højden på arbejdskraftens pris og arbejdstidens længde. For det var nu muligt for fagforeningerne (og endnu mere for arbejdernes repræsentationsorganer $\mathrm{i}$ virksomheder, virksomhedsrådene) at gennemføre arbejdstidsforkortelser og lønforhøjelser. Industriarbejdernes gennemsnitlige antal ugentlige arbejdstimer faldt ikke mindst derfor i 60'erne fra 46,3 (1960) til 44,8 (1970) ${ }^{95}$.

Lønkvoten stiger (total økonomisk) fra 60,6\% til $66,7 \%{ }^{96}$, i industrien stiger lønstyksomkostmingerne fra 33,3\% til 48,3\% ${ }^{97}$. Arbejdstidsforkortel-

92. Jvf. Osterland m.fl. Materialien zur Lebens- und Arbeitssituation der Industriarbeiter in der BRD, Frankfurt a.M. 1973, Tabel 49 (i bilaget).

93. Ibid. Tabel 47.

94. I det følgende går vi ud fra, at andelen af de arbejdstimer, der ydes af de produktive arbejdere ligeledes er faldet; på basis af bestemte tekniske gennemsnitsbetingelser er naturligvis kun det produktive arbejde værdidannende.

95. Osterland m.fl., op.cit., Tab. 61 (i bilaget).

96. Sachverständigenrat, Jahresgutachten 1972, s. 146. Tab. 38.

97. Jvf. vores tabel 2, denne stigning betyder reelt kun en ubetydelig stigning, som det allerede ovenfor er fremstillet. 
serne og lønforhøjelserne måtte alt i alt have en negativ effekt på profitproduktionen.

Hvis vi derfor her opstiller den tese, at mervardiraten for den vesttyske $\mathrm{ka}$ pital i dette tidsrum i det mindste ikke falder, hvis den endda ikke kan forhøjes, så er det nødvendigt med oplysning først og fremmest om nogle videregående redegørelser for sammensætningen af arbejderbefolkningen.

Stigningen i lønkvoten, som det - selv om den er inflationært forfalsket bliver tydelig i vores figur 3, synes ved første blik i 60'erne at være den betydningsfuldeste faktor, der bevirker et fald i kapitalrentabiliteten. Således synes lønarbejdernes succes i konflikterne om lønhøjden og arbejdstidens længde at være årsagen til den kapitalistiske krise. Vi har allerede i indledningen henvist til, at der til dette fænomen knyttes teorier, der begrunder den kapitalistiske krise med det ændrede forhold mellem løn og profit, der skyldes de skærpede klassemodsætninger. Fejlen ved denne argumentation ligger ikke i, at klassekampene, der virkelig skærpes, ikke udgør et tryk på kapitalens valoriseringssituation (for så vidt resultaterne af lønkampene ikke delvis igen kan tages tilbage gennem forhøjelsen af prisniveauet). Fejlen ligger på den ene side i, at der ikke tages hensyn til den langsigtede for kapitalvaloriseringen bestemmende forandring af forholdet mellem dødt og levende arbejde, der kommer til udtryk i den faldende tendens for kapitalproduktiviteten $(\mathrm{Y} / \mathrm{K})$ i vores figur.

Men derudover bliver en sådan betragtningsmåde falsk, fordi den industrielle lønkvote ved en kortslutning (i vores tilfælde forholdet mellem indkomsten fra uselvstændigt arbejde i industrien og nettoproduktionsvolumen) sættes lig med mervardiraten. I den industrielle lønkvote indgår nemlig ikke blot lønninger til arbejderne, der deltager i produktionen af merværdien, men der indgår også

a) profitbestanddele, for så vidt de bliver udbetalt til kapitalens ledelsesfunktionærer i form af overproportionale høje gager - det er her betydningsfuldt - og

b) lønninger til kapitalens uproduktive arbejdere (cirkulationsagenter etc.) der bliver betalt af merværdifonden.

For de uproduktive arbejdere producerer ingen værdi respektive merværdi, den vækst, der finder sted hos denne del af de lønafhængige, afhænger væsentligt af udviklingen i arbejdets produktivkraft i det produktive område af den industrielle kapital. Derfor fremkalder den expansion i de uproduktive arbejderes andel af den samlede arbejdskraft på den ene side ingen yderligere merværdi, men indskrænker det akkumulationsdygtige merprodukt. På den anden side får den stigende andel af uproduktive arbejdere lønkvoten til at stige og udbytningsgraden synes at falde, når lønkvoten på denne fejlagtige måde sættes sammen med merværdiraten. Dette gælder på samme måde for den totalsamfundsmæssige lønkvote, blot indgår der i den totalsamfundsmæssige lønkvote yderligere uproduktive lag af lønafhængige, så som statslige lønarbejdere, der betales ud af de lønafhængiges revenue etc. 
$\mathrm{Nu}$ foreligger der ganske vist nyere undersøgelser af klassestrukturen i BRD og dermed også undersøgelser, der kan bestemme udviklingen i de uproduktive arbejderes andel ${ }^{98}$, men disse unders $\emptyset$ gelser bestemmer ikke andelen af de uproduktive lønarbejderes lønsum af den samlede lønsum. Men da en vækst i den uproduktive arbejdsmasse på ingen måde nødvendigvis også indeholder en vækst i den lønfond, der forener disse arbejder med hinanden, vil vi først og fremmest søge at finde indikatorer for udviklingen i de uproduktive arbejderes andel af lønkvotens udvikling ud fra den officielle statistik. For at få en indikator for merværdiens udvikling, vender vi tilbage til den tidligere udviklede sammenhæng: Ud fra de uproduktive arbejderes stigende andel af lønsummen og af lønkvotens udvikling slutter vi, at merværdiraten er stigende - forudsat, at lønningerne udvikler sig på nogenlunde samme måde indenfor de forskellige områder. I dette øjemed vil vi undersøge statistikken ved hjælp af følgende ligning:

$$
\frac{\mathrm{W}}{\mathrm{Y}}=\frac{\left(\mathrm{a}_{\mathrm{pr}}+\mathrm{a}_{\mathrm{upr}}+\mathrm{ast}_{\mathrm{s}}\right) \mathrm{W}}{\mathrm{Y}}
$$

I denne ligning er Y (nettoproduktet) en funktion af de produktive lønarbejdere, sådan som vi allerede har fremstillet det i artiklens første del. Videre er:

$\mathrm{a}_{\mathrm{pr}} \quad$ lig med de produktive arbejderes andel af lønsummen i forhold til den samlede lønsum $\left(=\mathrm{W}_{\mathrm{pr}} / \mathrm{W}\right)$.

$\mathrm{a}_{\text {upr }} \quad$ lig med kapitalens uproduktive arbejderes andel i forhold til den samlede lønsum $\left(=\mathrm{W}_{\text {upr }} / \mathrm{W}\right)$.

$\mathrm{a}_{\mathrm{St}} \quad$ lig med de statslige arbejderes andel af lønsummen i forhold til den samlede lønsum $\left(=\mathrm{W}_{\mathrm{St}} / \mathrm{W}\right)$.

Ud fra denne ligning er det klart, at en hurtigere tilvækst af $\left(a_{\text {upr }}\right.$ og $\left(a_{\mathrm{St}}\right)$ i forhold til $\left(\mathrm{a}_{\mathrm{pr}}\right)$ får andelen af de produktive arbejdere til at falde. Deraf ville følge a) ved konstant lønkvote må merværdiraten være steget;

b) ved stigende lønkvote kan merværdiraten være konstant eller endog stigende; den kan således være faldet, hvis de samlet lønforhøjelser havde overkompenseret endog tilvæksten i de uproduktive arbejderes lønsum og hos de erhvervsaktive, der er beskæftiget af staten. (Men da stigningsraten for lønkvoten ikke umiddelbart er til at sammenligne med stigningsraten for andelen af de uproduktive arbejdere, må vi nøjes med de anførte indikatorer i det følgende).

Hvis vi går ud fra, at den overvejende del af de produktive arbejdere er sammenfattet under rubrikken »producerende erhverv«, bliver det tydeligt ud fra tabel 8, at andelen af de områder, inden for hvilke den største del af de uproduktive arbejdere er opgjort (handel, transport, tjenesteydelser, stat), har expanderet overproportionalt i forhold til de »produktive områder « i 60'erne: Andelen af de lønsummer, der kan forbinde de »uproduktive områder « med

98. Projekt Klassenanalyse, Materialien zur Klassenstruktur der BRD, Berlin (Vest) 1974; IMSF, Klassen- und Sozialstruktur der BRD 1950-1970, Teil II, Sozialstatistischer Analyse, Frankfurt a.M. 1973. 
Tabel 8:

Lønandele og lønudvikling i forskellige sektorer i den vesttyske økonomi.

\begin{tabular}{|c|c|c|c|c|c|c|}
\hline \multirow[t]{2}{*}{ Brancher } & \multicolumn{2}{|c|}{$\begin{array}{c}\text { Bruttoindkomster } \\
\text { fra uselvstændigt } \\
\text { arbejde }\end{array}$} & \multirow[t]{2}{*}{$\begin{array}{c}\text { Brutto- } \\
\text { indkomst } \\
1970 \text { sam- } \\
\text { menlignet } \\
\text { med } 1960 \\
(1960= \\
100)\end{array}$} & \multicolumn{2}{|c|}{$\begin{array}{l}\text { Branchens } \\
\text { bruttoind- } \\
\text { komst i } \\
\text { andel af den } \\
\text { totale brut- } \\
\text { toindkomst }\end{array}$} & \multirow[t]{2}{*}{$\begin{array}{c}\text { En- } \\
\text { dringer i } \\
\text { andele .. } \\
\text { fra } 1960 \\
\text { til } 1970 \\
\text { pct. }\end{array}$} \\
\hline & 1960 & 1970 & & 1960 & 1970 & \\
\hline $\begin{array}{l}\text { Produktive } \\
\text { områder }\end{array}$ & & & & & & \\
\hline $\begin{array}{l}\text { Land- og } \\
\text { skovbrug: }\end{array}$ & 2670 & 3520 & 131,8 & 1,9 & 1,0 & $-47,4$ \\
\hline $\begin{array}{l}\text { Energi og } \\
\text { minedrift: }\end{array}$ & 6620 & 9450 & 142,8 & 4,7 & 2,7 & $-42,5$ \\
\hline $\begin{array}{l}\text { Fremstillings- } \\
\text { virksomhed } \\
\text { (excl. byggeri): }\end{array}$ & 61670 & 154700 & 250,9 & 43,5 & 43,9 & 0,1 \\
\hline Byggeri: & 12750 & 31640 & 248,2 & 9,0 & 9,0 & 0,0 \\
\hline Industri: & 50310 & 125600 & 248,4 & 35,5 & 35,7 & 0,1 \\
\hline $\begin{array}{l}\text { Ialt: } \\
\text { Uproduktive } \\
\text { områder }\end{array}$ & 83710 & 199330 & 238,1 & 59,1 & 56,6 & $-4,2$ \\
\hline $\begin{array}{l}\text { Handel, } \\
\text { transport og } \\
\text { nyhedsformidling: }\end{array}$ & 23520 & 57170 & 243,1 & 16,6 & 16,2 & $-2,4$ \\
\hline $\begin{array}{l}\text { Kredit, forsikring } \\
\text { og lign. tjeneste- } \\
\text { ydelser: }\end{array}$ & 9200 & 25960 & 282,2 & 6,5 & 7,4 & 13,8 \\
\hline Stat: & 20580 & 59280 & 290,1 & 14,5 & 16,8 & 15,9 \\
\hline Ialt: & 53300 & 142410 & 267,2 & 37,6 & 40,4 & 7,5 \\
\hline Totalt: & 141760 & 352140 & 248,4 & - & - & - \\
\hline
\end{tabular}

Kilde:

Statistisches Jahrbuch 1973, s. 522f; DIW, Produktionsvolumen ..., op. cit., egne beregninger. Andele af bruttoindkomsten for uselvstændigt arbejde giver ikke 100 p.gr.a. dobbelttælling (industrien er indeholdt i fremstillingsvirksomhed). 
hinanden, stiger med 7,5\%, mens andelen af de "produktive områders « lønsum falder i forhold til den samlet lønsum med 4,2\%. Taget hver for sig stiger endog andelen af lønsummen for de lønarbejdere, der er sammenfattet under »tjenesteydelser «, med 13,8\% og for de erhvervspersoner der er beskæftiget af staten, med $15,9 \%$. Den antagelse, at den overproportionale stigning i de uproduktive arbejderes lønsum kan føres tilbage til en stigende andel af lønafhængige overhovedet, bliver bekræftet af Projekts Klassenanalyses tesultater, skønt indordningen af de erhvervsaktive under de enkelte arbejderkategorier dér sker mere differentieret, end det her er muligt. Ifølge Projekts Klassenanalyse forskydes andelen af kapitalens uproduktive arbejdere i forhold til arbejderklassen fra 13,0\% (1950) til 22,2\% (1961) og stiger videre indtil 1970 til en andel af $25,3 \% \%^{99}$. Samtidig forhøjes andelen af de erhvervspersoner, der beskæftiges af staten, fra $11 \%$ (1950) til næsten $16 \%$ i $1970^{100}$.

Udviklingen i de forskellige arbejderlags andel af nyværdien bliver ikke tydelig gennem disse tal, dog kan man - hvis man stiller resultaterne fra tabel 8 ved siden af denne analyse af strukturforskydningen - slutte fra forandringen i de uproduktive arbejderes andel til ugunst for de produktive lønarbejdere, at de produktive arbejderes produktivkraft er steget og at merværdiraten, trods den tilsyneladende modsatvirkende stigning i lønkvoten, i det mindste er forblevet konstant, hvis ikke den end og er steget.

Lønarbejdernes stigende andel af nettoproduktet (her: de uselvstændigt beskæftigedes andel af nationalindkomsten) er derfor udtryk for de uproduktive arbejderes stigende andel af de beskæftigede, der betales af merværdien og hvis stigende andel således er udtryk for en høj og sandsynligvis endog stigende merværdirate. For så vidt lønarbejderne i 60'erne virkelig kan gennemføre reallønsforhøjelser (og vi har allerede henvist til, at dette i højere grad er muligt nu end i 50'erne), får de del i udviklingen af det produktive arbejdes produktivkraft uden at sænke merværdiens rate. Dette bliver også tydeligt ved en sammenligning af udviklingen $i$ arbejdsproduktiviteten med udviklingen i de reale nettolønninger ${ }^{101}$ :

99. Projekt Klassenanalyse, op.cit., s. 219, Tab. 41.

100. Ibid., s. 423.

101. De følgende værdier, der er angivet i tabel 9, refererer dog kun til den totalsamfundsmæssige arbejdsproduktivitet og de reale nettolønninger hos de erhvervsaktive. I beregningen af arbejdsproduktiviteten indgår der uproduktive områder, i hvilke udviklingen af arbejdets produktivitet ikke umiddelbart berører merværdiproduktionen inden for det produktive område. En stigende produktivitet inden for disse områder ville kun formindske fradraget i den totalsamfundsmæssige akkumulerbare merværdi. Desuden sænkes det totalsamfundsmæssige »måltal « for produktivitetsudviklingen betydeligt, da produktivitetsudviklingen indenfor disse uproduktive områder bevislig ligger betydeligt under produktivitetsstigningen indenfor kapitalens produktive områder. Også i nettolønnen indgår de uproduktive arbejderes lønninger, se ovenfor. En indvending, som blev fremhævet mod studiet af Bergmann m.fl., af nettolønnen ikke genspejlede virksomhedsejerens virkelige omkostningsbelastning (jvf. G. Müller, U. Rödel, koreferat til O. Jacobi og W. Müller-Jentsch, uoffentliggjort manuskr. Stranberg 1974, s. 2), rammer vores sammenhæng for så vidt som de statsudgifter, der finansieret over skatterne, også fuldt og helt indgår i arbejdskraftens værdi (uddannelsesudgifter, social sikring). Men dertil kan indvendes, at a) ikke det samlede skatteprovenu fra lønarbejdere igen indgår i arbejdskraftens reproduktion via statsudgifterne, b) ved denne indvending negeres fuldstandigt de uproduktive arbejderes rolle. 
Tabel 9:

Real produktivitetsstigning og reallønstigning.

\begin{tabular}{|c|c|c|}
\hline År & $\begin{array}{l}\text { Real BFI/beskæftigede } \\
\text { Tilvækst i pct. }\end{array}$ & $\begin{array}{l}\text { Nettoløn og gage pr. beskæftiget } \\
\text { arbejdstager. Tilvækst i pct. }\end{array}$ \\
\hline 1951-1958 & 5,5 & 5,3 \\
\hline $1959-1967$ & 4,6 & 4,6 \\
\hline 1968-1972 & 4,8 & 4,7 \\
\hline
\end{tabular}

Kilde:

J. Bergmann, O. Jacobi, W. Müller-Jentsch, Gewerkschaften in der BRD, Frankfurt/M (upubl. manuskript), s. 178; egne beregninger.

Ud fra denne modstilling, der refererer til et tidsrum, som nogenlunde modsvarer vores »faseinddeling «, bliver det i det mindste tydeligt, at de produktive og uproduktive lønarbejderes lønforhøjelser ikke indskrænker den akkumulationsdygtige merværdi, men bevirker, at de lønafhængige kan tilkæmpe sig en andel af udviklingen af det produktive arbejdes produktivkraft. Men samtidig bliver det også tydeligt, at en yderligere stigning i den akkumulationsdygtige merværdi gennem reallønssænkning, hvad der havde kunnet modvirke den faldende kapitalrentabilitet og også profitratens fald, begrænses af de lønafhængiges styrkede stilling. Det viser sig især i begyndelsen af 70'erne, hvor de lønafhængige søger at hindre kapitalens tryk på reallønnen.

\subsubsection{Kapitalstock og arbejdsproduktivitet}

Også udviklingen i kapitalstocken forløber anderledes i 60'erne end i 50'erne. Dette bliver allerede tydeligt ved, at tilvæksten i investeringerne i tidsrummet fra 1960 til 1970 (i 1962 priser) kun er 73\% overfor mere end 150\% i 50'erne. Dette resultat kommer i stand, selv om investeringskvoten, dvs. investeringernes andel af socialproduktet, er højere end i 50'erne. I industrien derimod falder investeringskvoten på lang sigt i dette årti, som det fremgår af følgende tabel (se s. 68).

Ganske tydeligt er her investeringskvotens cykliske bevægelse; men selv når man sammenligner konjunkturelle ens år (f.eks. 1960 og 1969), så er det tydeligt, at investeringskvoten falder på lang sigt. Også investeringernes struktur ændrer sig. Når man trækker afskrivninger ${ }^{102}$ fra bruttoinvesteringssummen for at få værdien af nettoinvesteringerne, så viser det sig, at andelen

102. Ang. problemet med vurderingen af afskrivninger såvel som beregningen af anlægsformuen jvf. Heinrich Lützel, Das reproduzierbare Sachvermögen zu Anschaffungs- und Wiederbeschaffungspreisen, i: Wirtschaft und Statistik, nr. 11/1972. 
Tabel 10:

Nettoproduktionsvolumen og bruttoanlægsinvesteringer i industrien $i$ 1962-priser.

\begin{tabular}{l|r|r|r|r|r|r|r|r|r|r|r}
\hline & 1960 & 1961 & 1962 & 1963 & 1964 & 1965 & 1966 & 1967 & 1968 & 1969 & 1970 \\
\hline $\begin{array}{l}\text { Effektiv nettoproduktions- } \\
\text { volumen (Mia. DM) }\end{array}$ & 151,1 & 160,0 & 166,1 & 170,9 & 186,7 & 197,4 & 199,6 & 194,1 & 217,1 & 245,2 & 260,3 \\
$\begin{array}{l}\text { Bruttoanlægsinvesteringer } \\
\text { (Mia. DM) }\end{array}$ & 19,3 & 21,1 & 20,9 & 19,3 & 20,3 & 22,3 & 21,7 & 19,4 & 18,8 & 24,6 & 27,9 \\
$\begin{array}{l}\text { Bruttoanlægsinvesterin- } \\
\text { gernes andel af netto- } \\
\text { produktionsvolumen i pct. }\end{array}$ & 12,8 & 13,2 & 12,6 & 11,3 & 10,9 & 11,3 & 10,9 & 10,0 & 8,7 & 10,1 & 10,7 \\
\hline
\end{tabular}

Kilde:

$D I W$, Produktionsvolumen, op. cit; egne beregninger.

af - modsvarende afskrivninger - reinvesteringerne i det nævnte tidsrum tiltager eller nettoinvesteringernes andel af bruttoinvesteringerne aftager. Denne »nettokvotes « bevægelse følger i det store og hele kapitalproduktivitetens bevægelse. Indtil midten af 50'erne stiger den (fra 55,6\% i 1950 til 67\% i 1955) for derefter kontinuerligt at falde (jvf. tabel 4a). Dette kan forklares med, at den fixe kapitalmasse - som følge af den stejlt stigende kapitaludgift - bliver stadig større - og derfor også - til dels også forstærket af den forkortede levetid på anlæg og ændringer i finansieringssystemet - nødvendiggør højere afskrivningsbel $\varnothing$ b. Når investeringskvoten ikke tilsvarende stiger eller falder, må det resultere i den forholdsmæssige og absolutte vækst i reinvesteringerne og den relative nedgang i nettoinvesteringerne. Dette har en yderligere effekt, nemlig om end ubetydelig - forsinkelsen af kapitalstockens tilvækstrate. Dette kan fremstilles ved hjælp af alle de størrelser, der indicerer fixkapitalens aktiver: Lægger man til grund nettoanlægsformuen i forhold til anskaffelsesprisen, så var tilvækstraterne fra 1960 til 1970 i erhvervsvirksomheder 142\%, i industri og håndværk $153 \%$ og i den statslige sektor 159\%. Betragter man nettoanlægsformuen i forhold til genskaffelsesprisen, så er tilvækstsraterne i det nævnte tidsrum hos virksomhederne $174 \%$, i industri og håndværk $175 \%$ og i den statslige sektor $203 \%$. Bruttoanlægsformuen i industrien, der tiltog fra 1950 til 1960 med 107\%, vokser i den følgende tiår nu kun med 85\% ${ }^{103}$. Heri viser der sig altså to ting: For det første, at kapitalstockens vækstrate i 60'erne bliver langsommere - en ubedragelig indikator for, at nettoinvesteringernes andel af de samlede investeringer går tilbage. Ydermere betyder dette, at den stærkt stigende investeringskvote i hele $\varnothing$ konomien, p.gr.a. det omfang som kapitalstocken i mellemtiden havde nået, ikke var tilstrækkeligt til at opnå lignende store tilvækstsrater for kapitalstocken - og dermed også for produktionskapa-

103. Ibid. s. 621 og egne beregninger. Også Krengel m.fl. op.cit. 
citeten - som det endnu var muligt i 50'erne. Med andre ord: Udvidelsen af produktionspotentialet bliver sværere, jo højere kapitalkoefficienten er eller jo lavere kapitalproduktiviteten er. Således siges det allerede i den anden redeg $\varnothing-$ relse af det økonomiske råd fra 1965: »Mens man i gennemsnit i årene fra 1951 til 1955 kun skulle investere 2,4\% af bruttonationalproduktet for at muliggøre en tilvækst i det reale bruttonationalprodukt med $1 \%$, var det nødvendigt i gennemsnit i årene fra 1959 til 1973 at investere 4,5\% af bruttonationalproduktet for at muliggøre en tilvækst i det reale bruttonationalprodukt med $1 \% 104$.

For det andet fremgår det af tallene, at i modsætning til 50'erne tiltager statens nettoanlægsformue stærkere end i håndværk og industri. Det viser, ligesom den stigende andel af statsligt beskæftigede af det samlede antal arbejdere og funktionærer, statens ændrede betydning i den vesttyske kapitals reproduktionsproces. Det vil vi vende tilbage til.

Således stiger ganske vist den absolutte tilvækstrate for kapitalstocken i 60'erne langsommere end i 50'erne; men da arbejdsvolumen i denne periode aftager, resulterer denne neddæmpede absolutte stigning dog i en accelereret tilvækstsrate for kapitalintensiteten. Deri kommer især det »tekniske fremskridts « karakter i 60'erne til udtryk. Vi vil gøre nogle bemærkninger til dette problem; bemærkninger, fordi vi ikke på dette sted er i stand til systematisk at behandle de komplekse problemer vedrørende den teknologiske udvikling, på den anden side kan vi dog ikke p.gr.a. denne problematiks vigtighed for kapitalakkumulationens udviklingsbetingelser i Vesttyskland give afkald på at udrede de dominerende tendenser.

Efter den neoklassiske forestilling er et neutralt teknisk fremskridt fremherskende, hvis det absolutte produktionsvolumen og produktionsvolumenen pr. arbejder stiger og kapitalindsatsen pr. arbejder (K/L) (lige som indkomstsfordelingen) forbliver konstant. Efter postkeynesiansk teori er der derimod tale om et neutralt teknisk fremskridt, hvis kapitalkoefficienten $\mathrm{K} / \mathrm{Y}$ (eller den reciprokke værdi, kapitalproduktiviteten $\mathrm{Y} / \mathrm{K}$ ) forbliver konstant, hvorved kapitalintensiteten kan stige, altså må arbejdsproduktiviteten stige tilsvarende. I Forbundsrepublikken iagttog vi i 60'erne en stigende kapitalindsats pr. arbejdskraft. Ved et givet produktionsniveau stiger produktionsmiddelindsatsen altså i forhold til det levende arbejde; arbejdskræfter bliver substitueret med produktionsmidler og bliver dermed frisat. Således stiger ved tiltagende produktionsomfang indsatsen af produktionsmidler relativ hurtigere end arbejdsindsatsen.

Denne forbindelse kan også formuleres anderledes: Skal kapitalproduktiviteten stige, så må kapitalindsatsen (præcisere: indsatsen af fix kapital) pr. arbejder stige langsommere end arbejdsproduktiviteten. I 60'erne stiger imidlertid kapitalintensiteten hurtigere end arbejdsproduktiviteten (jvf. tabel 2 og figur 3). Deraf kan man kun slutte, at det tekniske fremskridt i Vesttyskland i 60'erne fremfor alt har været arbejdsbesparende: Arbejdskræfter blev erstattet med fix kapital.

104. Sachverständigenrat, Jahresgutachten 1965, cif. 93. 
Denne empiriske fremtrædelse modsvarer også den marxske antagelse om den stigende tekniske kapitalsammensætning i løbet af kapitalakkumulationen. Efter den marxske teori tiltager produktionsmiddelindsatsen i forhold til det levende arbejde allerede ved et givet produktionsniveau i tidsforløbet (omvæltningen af originalkapitalen) og stiger relativt hurtigere i løbet af kapitalakkumulationen, således at også forholdet mellem dødt og levende arbejde tiltager. Lige så stiger værdisammensætningen eller kapitalens organiske sammensætning $\mathrm{c} / \mathrm{v}$ (forudsat, at indflydelsen fra forandringen af $\mathrm{v}$ elimineres).

Denne tendens gør sig også gældende i produktionsværdiens sammensætning. For her må også den konstante kapitals andel (eller den konstante fixe kapital, hvorudfra denne analyse udgår) tiltage i forhold til udgifterne til det levende abejde. At der også har været modtendenser hertil og vil være fremover er naturligt og afhænger ikke mindst af prisen på varen arbejdskraft i forhold til kapitalomkostningerne.

Den tese, at et neutralt eller oven i købet kapitalbesparende tekniske fremskridt periodevis eller langsigtet kunne være overvejende ${ }^{105} \mathrm{og}$ som ville modvise den marxske teori om overskudsarbejderbefolkningen og profitratens faldende tendens, passer i det mindste ikke for efterkrigsudviklingen i Forbundsrepublikken (især for 60'erne).

Hvilke konsekvenser har denne slags teknisk fremskridt og akkumulation for arbejdernes beskæftigelsessituation? Hvilke tendenser kan forventes for fremtiden? Da det levende arbejdes andel i forhold til produktionsmiddelindsatsen på et givet produktionsniveau aftog og det gik relativt tilbage med akkumulationen, kom det til en stadig frisættelse af og besparelse på arbejdskræfter ${ }^{106}$, hvis genbeskæftigelse foreløbigt var sikret gennem høje vækstrater og gennem den stadige kapitaludvidelse i 60'erne, idet de frisatte arbejdere fandt en genbeskæftigelse i de samme eller andre industrigrene. Sålænge raten for produktionsudvidelse og kapitaludvidelse endnu var tilstrækkelig stor i de samme eller andre produktionsgrene, gik denne proces med omplantning og genbeskæftigelse af de frisatte lønarbejdere nogenlunde lempeligt fra hånden, selv om dette også havde afskedigelse, omplantning, dekvalifikation og omskoling til følge ${ }^{107}$.

105. Denne tese forsvares af en række kritikere af den marx'ske lov om profitratens tendentielle fald, således af M. Blaug, Technical Change and Marxian Economics, i: Marx and Modern Economics, ed. by D. Horowitz, London 1968. Også B. Schefold, op.cit., går ud fra denne tese.

106. Frisættelse betegner den arbejdsmængde, der p.gr.a. produktivitetsstigninger ikke længere er nødvendig for at producere en bestemt mængde brugsværdier. Når der i 1968 til fremstilling af et nettoprodukt på 100 må indsættes 100 beskæftigede, så kan dette nettoprodukt på 100 i 1980 fremstilles af 54,4 beskæftigede. Frisættelsen er altså på 45,6\%. Man taler om besparelse, hvis man i 1980 sætter nettoproduktet til 100 som produceres af 100 beskæftigede og i 1968 behøver mere end 100 beskæftigede til at producere det; der bliver altså i løbet af udviklingen sparet arbejdskræfter til produktion af en givet mængde produkter. De her anvendte tal er for $\varnothing$ vrigt fra RKW-Studie, Berichtsband, Frankfurt 1970, s. 102 ff. Begreberne bliver også anvendt af Marx i samme betydning i 13. kapitel 1. bd. af Kapitalen.

107. Jvf. H. Kern og M. Schumann, Der soziale Prozess bei technischen Umstellungen, Frankfurt a.M. 1972. 
På den anden side - gennem den stærkere expansion af tjenesteydelsessektoren og de uproduktive områder, som fulgte af den accelerede akkumulation, fandt mange arbejdere her en beskæftigelse (jvf. også tabel 8). Når de frisatte arbejdere i BRD foreløbig i stor udstrækning fandt en genbeskæftigelse gennem disse to momenter, så betød det alligevel at enkelte arbejderlag og erhvervsgrupper blev udsat for en enorm belastning, dekvalifikation, degradering og forringelse af deres situation p.gr.a. den manglende forudseenhed og planlægning og af den naturgroede udvikling af produktionsstrukturerne i den kapitalistiske reproduktionsproces.

Men først i 70'erne viser dette problem sig i rigtig graverende udstrækning, idet den hidtidige latente industrielle reservearme fremtræder som virkelig industriel reservearme p.gr.a. nationalproduktets ringere vækstrater og ringere rater for kapitaludvidelsen (investeringsraterne er i BRD faldet stærkt $\mathrm{i}$ 70'erne), og reservearmeens genbeskæftigelse - lige så genbeskæftigelse af de arbejdere, der er blevet afskediget ved produktionsindskrænkning - er blevet umuligt for bestemte alders- og kvalifikationsgrupper. De sidste år i BRDs $\varnothing$ konomiske udviking viser derfor også tiltagende, omend endnu ikke dramatiske, arbejdsløshedsprocenter og en stigende industriel reservearme, der for nogle erhvervsgrupper og industrigrene bliver tungtvejende.

På dette sted skal der kun henvises til (uden nøjere analyse), at disse forandrede betingelser for produktionsprocessen, der har haft konsekvenser for arbejderklassen, også har haft følger for den statslige politik. Forandringen af den statslige uddannelsespolitik, især indenfor erhvervsuddannelsen, de forcerede foranstaltninger for at danne en »infrastruktur «, der er i overensstemmelse med produktionsbetingelserne ${ }^{108}$, den ændrede arbejdsmarkedspolitik (som den kommer til udtryk i loven om arbejdsfremmelse (Arbeitsförderung) i 1969, kan ikke begribes, hvis man ikke tager hensyn til de her analyserede forandringer i akkumulationsbetingelserne. Også den allerede omtalte kendsgerning, at netto-anlægsformuen netop i statssektoren i modsætning til 50'erne tiltager stærkere end indenfor det private område og at også den andel af arbejdskræfterne, der beskæftiges af staten, vokser i forhold til den samlede arbejdskraft, finder en plausibel begrundelse i disse processer ${ }^{109}$.

Under disse betingelser er det ikke forunderligt, at stigninger i arbejdsproduktiviteten medfører et fald i kapitalproduktiviteten eller en stigning i kapitalkoefficienten, der indicerer forholdet mellem dødt og levende arbejde. For at arbejdets produktivitet kan stige, må stadig større masser af konstant, frem-

108. Jvf. til denne problemkreds D. Läpple, Staat und allgemeine Produktionsbedingungen, Vestberlin 1973.

109. For at forebygge misforståelser, må vi understrege, at der ikke er nogen muligheder for direkte og quasi-automatisk gennemførelse af produktionsnødvendigheder inden for den statslige politik. Tværtimod fuldbyrdes denne gennemførelsesproces selv i form af konflikter, kriser, stridigheder og kampe. Disse processer bliver dog ikke unders $\emptyset$ gt i denne artikel. 
for alt fixe kapital indsættes. Som det tydeligt fremgår af figur 3, angår dette udsagn først og fremmest den industrielle sektor. Men det gælder også for hele $\varnothing$ konomien. I følgende tabel er de årlige vækstrater for arbejdsproduktivitet, kapitalintensitet og kapitalkoefficient (den reciproke værdi af kapitalproduktivitet) gengivet:

Tabel 11:

Vækstraten for arbejdsproduktiviteten og kapitalintensiteten; absolut størrelse af kapitalkoefficienten for hele økonomien, 1960-1970.

\begin{tabular}{lccccccccccc}
\hline & 1960 & 1961 & 1962 & 1963 & 1964 & 1965 & 1966 & 1967 & 1968 & 1969 & 1970 \\
\hline Produktivitet & 7,4 & 5,3 & 4,5 & 4,2 & 6,4 & 6,0 & 3,5 & 4,2 & 6,7 & 6,0 & 4,0 \\
Kapitalintensitet & 4,3 & 5,1 & 6,0 & 5,9 & 6,2 & 5,8 & 6,4 & 8,8 & 4,7 & 3,3 & 4,1 \\
Kapitalkoefficient & 3,3 & 3,3 & 3,4 & 3,5 & 3,5 & 3,5 & 3,6 & 3,8 & 3,8 & 3,7 & 3,7 \\
\hline
\end{tabular}

Kilde:

WiSta, 1971, s. 604; Jahresgutachten des Sachverständigenrates; egne beregninger.

Vi ser, at kapitalkoefficienten stiger lidt i dette årti, altså aftager kapitalproduktiviteten også i hele økonomien. Hvis ikke den økonomiske krise 1966/67 havde tilvejebragt meget høje produktivitetsstigninger, så ville stigningen i kapitalkoefficienten have været endnu højere. Når man betragter den samlede $\varnothing$ konomi, så er stigningen i kapitalindsatsen pr. arbejdsplads ikke blot ansvarlig for tilvæksten i kapitalkoefficienten eller for nedgangen i kapitalproduktiviteten, men også for $»$ kravet om infrastrukturinvesteringer « ${ }^{110}$. Stigende beløb af den producerede merværdi kunne imidlertid ikke længere uden videre forvandles til kapital, der tilegner merværdi, men de brugsværdier, der modsvarer dele af merværdien, går nu ind i de materielle produktionsforudsætninger, som staten må tilvejebringe. Således stiger også i dette tidsrum statens andel af byggeinvesteringerne fra 24,1\% til 27,7\%, mens de private virksomheders andel falder fra $33,1 \%$ til $28,8 \%$. Dette er ganske vist kun en grov indikator for den stigende betydninge af statslig tilvejebragt infrastruktur; men den viser dog de forandrede vækstsbetingelser, der udtrykker sig - som allerede fremført - i den faldende kapitalproduktivitet.

Allerede i afsnit 3.3.2. henviste vi til den stigende betydning af de uproduktive sektorer under aspektet: hvilke fremtrædelser skjuler sig bag den stigende lønkvote. Dette må behandles endnu engang for at kunne interpretere produktionsudviklingen. Hvis man betragter de forskellige produktivitetsmål, så viser der sig følgende billed:

110. Sachverständigenrat, Jahresgutachten 1969, cif. 53. 
Tabel 12:

Produktionsresultat $1970(1962=100)$

\begin{tabular}{l|c|c|c}
\hline & $\begin{array}{c}\text { pr. beskæftiget } \\
\text { arbejdstime }\end{array}$ & pr. arbejdere & pr. arbejdstime \\
\hline Hele industrien & 157,7 & 160,3 & 166,2 \\
Fremstillingsvirksomhed & 156,8 & 158,9 & 165,0 \\
Minedrift & 185,7 & 183,2 & 195,4 \\
\hline
\end{tabular}

Kilde:

WiSta 1971, s. 240.

Påfaldende er det, at produktionsresultatet pr. arbejdstime i alle områder indenfor industrien stiger hurtigere end produktionsresultatet pr. beskæftigede time. Grunden hertil kan kun ligge i, at i størrelsen »beskæftigede time« er indeholdt de ydede arbejdstimer for alle ansatte, dvs. cum grano salis de uproduktive arbejder. Mens vi således i brøkens nævner kan finde gennemsnittet for produktive og uproduktive arbejdere (»pr. beskæftigelses time«), har vi i tælleren produktionsresultatet, der er resultatet af en del af de beskæftigedes arbejde, nemlig de produktive arbejdere. Selvom udsagnet kun gælder i denne stringens, når man anlægger den marxske begrebsramme, da jo de uproduktive beskæftigede i den borgerlige beregning af produktionsresultatet også tæller som værdidannende (som besidder af indkomst er de jo per se »produktive«), så kommer dog selv i denne statistik - om end fordrejet - forskellen mellem produktive og uproduktive arbejdere til udtryk. Den allerede i det forrige afsnit konstaterede udvidelse af det uproduktive område var kun mulig derved, at arbejdets produktivkraft steg meget kraftigt i den produktive sektor.

Statistisk kommer dette til udtryk ved, at indenfor landbrug og skovbrug, i fremstillingsvirksomhederne, indenfor energi og minedrift, altså indenfor områder, der i overvejende grad beskæftiger produktive arbejdere, ligger produktivitetsudviklingen over gennemsnittet for alle $\emptyset$ vrige samfunds $\varnothing$ konomiske områder, hvorimod den indenfor alle andre uproduktive områder ligger under gennemsnit ${ }^{111}$. Således viser det sig, at den konstaterede udvidelse af det uproduktive område, som vi tager hensyn til for at vise, at en stigende lønkvote ikke ubetinget er resultatet af en faldende merværdirate, kun var mulig p.gr.a. den stærke produktivitetsstigning indenfor den produktive sektor. Dette bekræfter imidlertid vore tidligere overvejelser fra en anden side: Den stigende arbejdsproduktivitet indenfor det produktive område er resultatet af en stigende merværdirate. Men udvidelsen af de uproduktive

111. RKW-Studie, Berichtsband op.cit., s. 29. 
områder skete på bekostning af den merværdi, der skulle til for at »finansiere « akkumulationen indenfor det produktive område. Men det betyder, at der tendentielt er sat grænser for udvidelsen af de uproduktive sektorer, da det kun er muligt at udvide dem ved enorme stigninger i arbejdsproduktiviteten. Da det imidlertid under de givne forhold er nødvendigt med meget store udgifter til fixkapital for at få arbejdsproduktiviteten til at stige og da kapitalkoefficienten følgelig stiger, vil en sådan tendens ikke kunne sætte sig igennem. Dette går imod alle de teorier, der går ud fra en sækular stigning i den »tertiær sektor « og i den forbindelse kun extrapolerer tendenser uden at kunne begribe deres modsigelsesfuldhed.

Lad os nu gå over til at betragte produktivitetsudviklingen under aspektet kapitalakkumulationens cykliske bevagelse. Allerede ved det første blik på de i tabel 11 gengivne vækstrater er det påfaldende, at arbejdsproduktivitetens tilvækstsrater falder før krisen for derefter igen at ryge i vejret. Med kapitalintensitetens tilvækstsrater er det lige netop omvendt, således at kapitalproduktiviteten stiger hhv. kapitalkoefficienten falder kortfristet efter kriser. Det er på den måde, at krisens funktion dokumenteres, nemlig igen at hæve kapitalvaloriseringen op på et så højt niveau, at en fornyet akkumulationsfase kan begynde. Efter krisen 1966/67 talte det økonomiske råd om et »produktivitetsmirakel «; rådets forklaring ville være værd at citere udførligt på dette sted:

»Årsagen til »produktivitetsmiraklet« ser nogle i den høje udnyttelse af produktionspotentialet i dette boom, andre henviser til recessionens nyttige virkning. Men man kan også tænke sig, at kapitalproduktiviteten på længere sigt igen ville forøges. - Kortsigtet kan arbejdsproduktiviteten forøges overgennemsnitligt derved, at med stigende udnyttelse af den faste kapacitet bliver virksomhedernes fixe elementer indenfor personale-bestanden anvendt bedre. Set ud fra recessionsdalen i 1966/67 var følgelig forudsætningerne for kraftige produktivitetsstigninger særlig gunstige ... Ved overgangen fra mindre til fuld (kapacitets) udnyttelse måtte man delvis gå tilbage til, at produktivitetsstigningen blev kraftigt accelereret. Åbenbart skulle der først en konjunkturel anspændelse til som i 1969 for at bevæge arbejdsgiverne til fuldt at mobilisere deres produktionsreserver. Antallet af arbejdsgivere, der i 1969 er overgået til skifteholdsarbejde, eller har indsat ekstra skift, måtte have været betydelig større end i den sidste højkonjunktur; det er længe siden, at der er blevet ydet så mange overtimer som i dette år (1969). - Der er også blevet henvist til, at de høje produktivitetsstigninger aldrig havde kunnet opnås uden den forgangne recession, og at der åbenbart fra tid til anden behøves en »renselseskrise « for at få gunstige vækstsbetingelser. Man kan vel ikke bestride, at recessionen har spillet en rolle for "produktivitetsmiraklet « - som modpost til produktivitetstabene i denne tid. Mange virksomheder har standset foraldede produktionsanlag og lægger sig efter investeringer med høj rationaliseringseffekt. Ofte kunne de stramme deres produktion og distribution, dels gennem tekniske og organisatoriske fornyelser i egne virksomheder, dels gennem sammenslutning med andre virksomheder eller gennem afstemning af produktionsprogrammet ... i 1968 og $1969 \mathrm{er}$ kapitalproduktiviteten i den samlede $\varnothing$ konomi dog alt at dømme ikke gået så stærkt tilbage, som hvis den havde modsvaret den langsigtede tend. For denne tese taler fremfor alt, - at bølgen med arbejdstidsforkortelse, der satte ind i begyndelsen af 60'erne, er stagneret efter recessionen (og vel heller ikke i overskuelig tid længere kan nå den udstrækning som i de senere år), at andelen af de private udstyrsinvesteringer i forhold til de samlede investeringer er for $\varnothing$ get og at de private udstyrsinvesteringer - målt i bruttonationalproduktet - endnu aldrig har været 
så store som i 1969, hvad der har ført til en forbedring af vores kapitalstocks alderstruktur, - at der i de sidste år er blevet udviklet mange nye arbejdsbesparende teknikker og metoder der er blevet bragt til produktionsmodning (som f.eks. indsatten af computers i planlægning, styring og kontrol af produktionsprocessen), og som først fuldt ud i denne cyklus' opsvingsfase har givet sig udslag i kapitalproduktivitet ... $\ll^{112}$.

Kort: Produktivitetsstigningerne er blevet fremkaldt af (a) arbejdets intensivering (»stærkere udnyttelse af de fixe elementer i personalebestanden«), (b) fuld udnyttelse af kapaciteterne, (c) mobilisering af reserverne, (d) udvidelse af arbejdstiden (flerskiftsdrift, overarbejde, ingen arbejdstidsforkortelser), (e) nedlæggelse af »forældede« anlæg, altså reducering af den konstante kapital, (f) rationalisering og effektivisering af produktion og cirkulation, (g) koncentration og centralisation af kapitaler, (h) delvis indførelse af arbejdsbesparende teknikker og metoder.

I krisen bliver altså endnu engang alle de muligheder mobiliseret, der også i 50'erne har været årsag til de høje tilvækstsrater i arbejdsproduktiviteten. Det $\varnothing$ konomiske råd har i denne sammenhæng endnu tilladt sig den illusion at antage, »at kapitalproduktiviteten på længere sigt igen forøges«. Men krisen er kun et moment i kapitalakkumulationens langsigtede bevægelse. I den gør på kort tid de modvirkende årsager til kapitalrentabilitetens fald sig gældende, men uden at kunne ophæve de tilgrundliggende tendenser for akkumulationsprocessen. Heraf kommer det, at fra ca. 1970 sætter de grundliggende tendenser til stærkere stigning i kapitalintensiteten overfor stigningen i arbejdsproduktiviteten sig igen igennem med den konsekvens, at der bliver en yderligere nedgang i kapitalrentabiliteten.

\subsubsection{Udviklingen i branchestrukturen}

Ved fremstillingen af de grundlæggende tendenser og betingelser for kapitalakkumulationen i 50'erne har vi henvist til, at branchestrukturen har været særlig gunstig for den vesttyske $\varnothing$ konomis stærke verdensmarkedssammenfletning og at omvendt den stærke verdensmarkedsafhængighed fremmede denne branchestruktur med hovedvægten på maskinbygning, kemi, elektroindustri, bilindustri osv. Dette fortsætter også i 60'erne, som det fremgår af følgende opgørelse, hvor alle de grene er opført, hvis exportandel af den samlede omsætning er højere end gennemsnittet på 19,5\% for den samlede industri (se tabel 12a, s. 76).

Af tabellen fremgår det, hvor stærkt ikke blot hele den vesttyske industri, men især nogle vigtige brancher er afhængige af verdensmarkedet. De kapitaler, der er anlagt i disse grene, kan kun akkumulere, hvis verdensmarkedet expanderer i samme grad som deres akkumulation. Men på den anden side indvirker verdensmarkedet over importsiden på branchestrukturen. For nemlig i passende udstrækning og varighed at kunne exportere, må importen som

112. Sachverständigenrat, Jahresgutachten 1969, cif. 50-54. 
Tabel 12a:

Eksportomsætningens andel af totalomsætningen i særlige eksportintensive brancher 1971.

\begin{tabular}{ll}
\hline Kulminedrift & 24,1 \\
Kali- og stensaltsminedrift & 28,3 \\
Andet minedrift & 20,3 \\
Jernproducerende industri & 27,2 \\
Kemisk industri & 30,8 \\
Kunststofindustri & 23,4 \\
Maskinindustri & 35,2 \\
Bilindustri & 40,6 \\
Skibsbygning & 42,6 \\
Elektroteknisk industri & 21,3 \\
Finmekanik, optik & 34,6 \\
Kontormaskiner, datamaskiner & 44,6 \\
Finkeramik & 29,4 \\
Musikinstrumenter mv. & 26,1 \\
\hline Totalt & 19,5 \\
\hline
\end{tabular}

Kilde:

Statistisches Jahrbuch 1973, s. 233.

»modpost « udvides. Men de importerede varer konkurrerer med de vesttyske enkeltkapitalers varer. På den måde kan det ske, at bestemte brancher, hvis produkter kan fremstilles i andre lande under gunstigere betingelser end i Vesttyskland, kommer i økonomiske vanskeligheder, som det var tilfældet i 50'erne indenfor minedriften, indenfor landbruget og i dag fremfor alt indenfor tekstilindustrien. Selvom i BRD størstedelen af importen består af produkter fra industri og håndværk, så er det dog nødvendigt at henvise til differencen mellem indførsels- og udførselsstrukturen: I indførsel i 1970 er andelen af industrielle færdigvarer nøjagtig 50\%, mens den i udførsel er 85,8\%. Og indenfor produkter fra industri og håndværk ligger hovedvægten i den vesttyske export på produktionsmidler, mens det indenfor importområdet ligger på forbrugsvarer. Betegnende nok exporterede den vesttyske kapital i 1972 for 4,1 mia. DM tekstil- og læderindustrimaskiner, hvilket stod overfor en import til et beløb af 0,6 mia. DM, mens der i det samme år er blevet exporteret for 3,1 mia. DM tekstiler, sko og andre lædervarer, er der derimod blevet importeret for 7,9 mia. DM. Dette er kun et eksempel, der skal vise, at ikke blot exportforholdene, men også importen er relevant for branchestrukturens udvikling. 
Når der på den ene side bliver spurgt om, hvilke virkninger, som verdensmarkedssammenfletningen har på branchestrukturen, så må på den anden side de betingelser undersøges, der bestemmer branchens position på verdensmarkedet. For at komme nærmere ind på denne problemstilling, vil vi nu betragte de vigtigste brancher indenfor den vesttyske industri ud fra deres relative stilling (indenfor den samlede industri) men hensyn til arbejdsproduktivitet, kapitalintensitet, lønkvote og kapitalrentabilitet. Først og fremmest unders $\varnothing$ ger vi industrigruppen indenfor minedrift, fremstillingsvirksomheder og deres undergrupperinger: råstof- og produktionsmiddelsindustrier, investeringsindustrier, konsumvareindustrier og nærings- og nydelsesmiddelindustrier.

\section{Figur 5:}

Kapitalrentabilitetens udvikling i udvalgte industrigrupper 1960-1971.

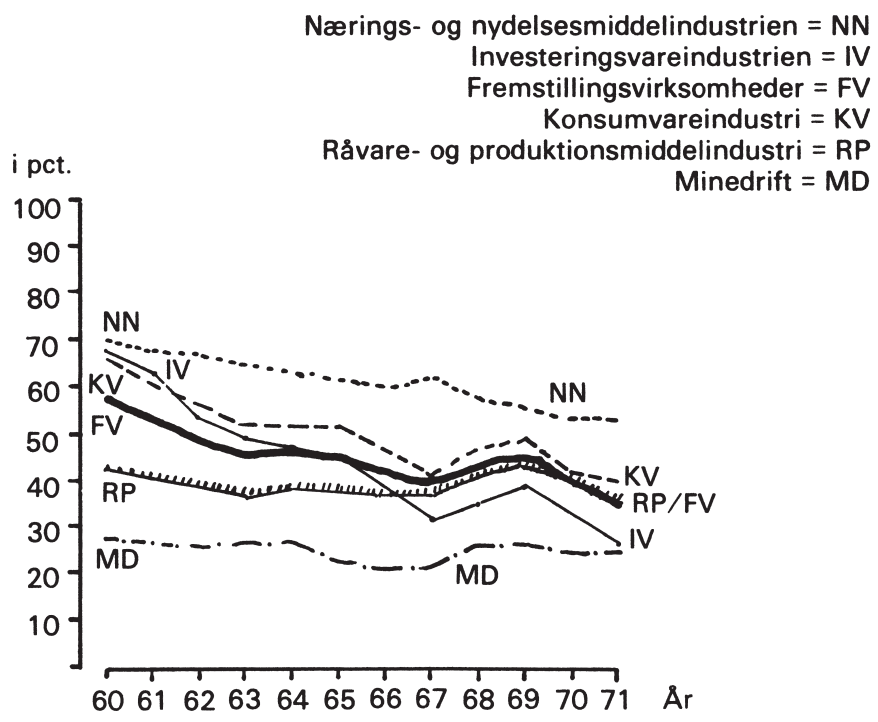

Kilde:

Egne beregninger på basis af data fra R. Krengel, o.a., op. cit.

I figur 5 har vi beregnet kapitalrentabiliteten for disse industrigrupper i 60'erne. For det første er det ved et $\varnothing j$ jekast tydeligt, at kapitalrentabiliteten bevæger sig cyklisk og i denne proces falder på lang sigt. For det andet er den særlige stærke nedgang i kapitalrentabiliteten i investeringsvareindustrierne påfaldende. Til disse brancher hører maskinbygning, bilindustri, elektroteknisk 
industri osv. Vi kan forklare dette med, at arbejdsproduktiviteten i disse grene ligger lavere end gennemsnittet for den samlede industri og at lønandelen af nettoproduktionsvolumen (styklønsudgifterne) er overgennemsnitlige $h \emptyset^{113}$. Den undergennemsnitlige kapitalintensitet har ikke kunnet holde den særlig stærke nedgang i kapitalrentabiliteten tilbage. For det tredje er der endnu noget påfaldende ved kurvernes forløb: Kapitalrentabilitetens aktuelle højde i de enkelte industrigrupper ligger nærmere hinanden i krisetider end i boomfaser. $\mathrm{Vi}$ vil ikke yderligere hengive os til dette problem i denne artikel, dog mener vi, at dette fænomen kun kan interpreteres, hvis vi undersøger tendenserne til udligning af de enkelte brancheprofitter til gennemsnitsprofitter, altså skulle problemet om konkurrence og monopol inddrages i betragtningen.

Vi kan imidlertid ikke være tilfredse med denne foreløbige grove karakteristik af den forskelligartede brancheudvikling, da de fremtidige udviklingstendenser væsentligt afhænger af, hvilke faktorer der er årsag til, at kapitalrentabiliteten falder. Kapitalens reaktionsmuligheder er forskellige alt efter de årsager, der er ansvarlige for kapitalrentabilitetens fald. Principielt kan den falde som følge af en stigende kapitalintensitet, en faldende arbejdsproduktivitet hhv. et gab mellem vækstraterne for kapitalintensitet og arbejdsproduktivitet eller en stigende lønkvote hhv. stigende lønstyksudgifter. Hvis vi kombinerer disse faktorer, så kan vi finde hovedgrundene til den aftagende kapitalrentabilitet. Ved undersøgelsen af de vigtigste brancher viste følgende resultat sig:

For det første: Kun i tre brancher forbedredes kapitalrentabiliteten i 60'erne, nemlig indenfor kemiindustrien, mineralolieforarbejdningen og kunststofforarbejdningen. Her spillede de ekstraprofitter, som disse industrigrene kunne erhverve sig som følge af deres særstilling i kapitalens reproduktionsproces (branchegruppe III) sikkert også en rolle.

For det andet: Hos næsten alle de brancher, der i 1960 lå over gennemsnittet for industrien i kapitalvaloriseringen, og som i 1971 er sunket til under gennemsnittet (branchegruppe I), viser der sig en ensartede konstellation: kapitalintensiteten og arbejdsproduktiviteten ligger under gennemsnittet for den samlede industri, kapitalproduktiviteten er overgennemsnitlig høj, ligeså også lønkvoten med det resultat, at kapitalrentabiliteten i løbet af 60'erne er blevet lavere end gennemsnittet. Betegnende nok lå alle disse brancher - stål- og letmetalfremstilling, maskinbygning, finmekanisk og optisk industri, finkeramisk industri, glasindustri, læderindustri lige som investeringsvareindustrien i sit gennemsnit - endnu i 1960 over gennemsnittet for den samlede industris kapitalrentabilitet. Hvis man stadig henregner de industrigrene til disse grupper,

113. Vi henviser endnu engang til, at ved beregning af styklønsomkostninger er lønudviklingen ikke blevet deflateret og derfor opstår der naturligvis en forfalskning af styklønsomkostningerne. Alligevel er det muligt at anvende styklønsomkostningerne i denne sammenhæng, da dette problem jo angår alle brancher og derfor er sammenligningsmuligheden fremstillet, hvilket det her drejer sig om. 
hvis kapitalproduktivitet er undergennemsnitlig, og som derfor også allerede i 1960 lå under gennemsnittet for kapitalvaloriseringen (tekstilindustri og skibsbygning), så har vi en relevant gruppe af industrigrene, hvis kapitalrentabilitet er faldet stærkt overgennemsnitligt, fordi styklønsudgifterne ligger meget højt. Som følge af den høje lønkvote søger disse grene deres frelse især ved en nedsættelse af lønandelen.

For det tredje: Derudover er der endnu en række andre industrigrene, hos hvem faldet i kapitalrentabiliteten er indtrådt af forskellige grunde - dels p.gr.a. en høj og stigende lønkvote, dels p.gr.a. meget hurtigt forceret kapitalintensivering eller for langsomt stigende arbejdsproduktivitet. Her kunne detaljerede branchespecifikke unders $\emptyset$ gelser, som vi ikke her kan gennemføre, give flere oplysninger.

\section{Figur 6:}

Kapitalrentabilitetens bevægelse i nogle brancher i den vesttyske økonomi fra 1960 til 1971.

Pct.

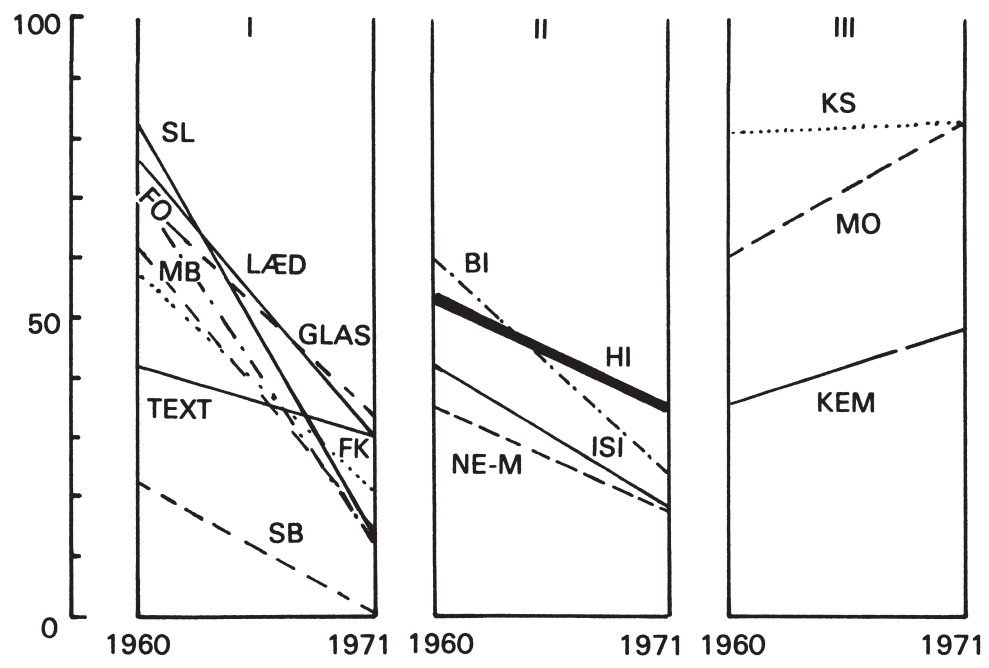

SL = stål- og letmetalanlæg; FO = finmekanik og optik; LÆD = læderindustri; $\mathrm{MB}=$ maskinbygning; FK = finkeramisk industri; TEXT = tekstilindustri; $\mathrm{SB}=$ skibsbygning; $\mathrm{BI}=$ bilindustri; JSI = jern- og stålindustri; NE-M = NE-metalindustri; $\mathrm{KS}$ = kunststofindustri; $\mathrm{MO}$ = mineralolieindustri; $\mathrm{KEM}=$ kemisk industri; GLAS = glasindustri; $\mathrm{HI}=$ hele industrien.

Kilde:

Egne beregninger på basis af data fra Krengel, o.a., op. cit. 
Ved hjælp af figur 6 kan vi tydeliggøre denne forskellighed i brancheudviklingen. Vi har opdelt de undersøgte brancher i tre grupper. I gruppe I befinder alle de brancher sig, hvis kapitalrentabilitet i tiåret fra 1960 til 1970 falder overgennemsnitligt p.gr.a. undergennemsnitlig kapitalintensitet og arbejdsproduktivitet, til dels overgennemsnitlig kapitalproduktivitet, men relative høje lønudgifter. I gruppe II befinder sig de vigtigste brancher med forholdsvis lav kapitalrentabilitet, men med høj kapitalintensitet, således at faldet $\mathrm{i}$ kapitalrentabiliteten her fremfor alt beror på kapitalintensiveringen. Den fedt optrukne linie i figuren for branchegruppe II betegner den samlede industris gennemsnit. I branchegruppe III befinder endelig alle de brancher sig, som i det forgangne tiår kunne notere en stigning i kapitalrentabiliteten. Det er alle de brancher med forholdsvis. høj arbejdsproduktivitet og lav lønandel.

Vi koncentrerer vores interesse om den første gruppe af industrigrene, hos hvem - for at gentage det - kapitalintensiteten og arbejdsproduktiviteten ligger under det industrielle gennemsnit, kapitalproduktiviteten som kombineret udtryk må ikke være ubetinget negativ og lønkvoten er overgennemsnitlig høj. Åbenbart beror den negative udvikling for kapitalrentabiliteten fremfor alt på de stærkt stigende styklønsudgifter. I hvert fald ser det sådan ud fra enkeltkapitalistisk standpunkt. Nu består der principielt to muligheder for at klare dette problem, nemlig for det første at spare på lønudgifterne gennem rationalisering, dvs. under de givne forhold at forhøje kapitalintensiteten, eller for det andet at udvandre til regioner, hvor lønudgifterne er meget ringe p.gr.a. særlige lave lønninger. Her må man skelne mellem to »typer« af brancher p.gr.a. deres forskellige arbejdsproces: de brancher, der har høj lønudgiftandel og samtidig høj andel af de højtkvalificerede arbejdskræfter og de brancher, der har høj lønudgiftandel og samtidig et stort antal af kun ringe kvalificerede arbejdskræfter. Særlig for den anden kategori af brancher, der udover tekstilindustrien består af den elektrotekniske industri, til dels bilindustrien den finmekaniske og optiske industri, læderindustrien, spiller den seneste udvikling, der kan iagttages i forbindelse med exporten ikke blot af varekapital, men også af pengekapital til anlæg i såkaldte lavtlønslande, en vigtig rolle. Uden nu at kunne gå nøjagtigere ind på de problemer, der ligger heri, skal vi blot pege på nogle tendenser, der er vigtige i vores sammenhæng.

For de enkelte kapitaler synes det, som om kapitalrentabilitetens fald fremfor alt beror på de meget stærkt stigende lønstyksudgifter. Den af os fremhævede sammenhæng mellem arbejdsproduktivitetens stigning, merværdiratens forh $\varnothing$ jelse, den uproduktive sektors stigende andel er skjult for den enkelte kapital. Således forsøger man at unddrage sig »omkostningsfaktoren « ved de høje lønninger, som efter den enkelte kapitals opfattelse er skyld i miseren med de forringede valoriseringsbetingelser. I den forbindelse spiller to »strategier « en rolle alt efter hvilken karakter, som sammenfletningen har indenfor verdensmarkedet. Når den vesttyske kapital ikke kan holde trit med priserne overfor konkurrenter 
fra andre lande, fordi der i produktets markedspris - ved meget arbejdsintensiv produktion - indgår høje lønninger, som de kapitaler, der producerer i de andre lande, ikke behøver at betale, så bliver først råbet om »beskyttelse mod udenlandsk konkurrence « højt. Handelsbegrænsninger, effektiv beskyttelsestold, protektion gennem forskellige subventionsformer er så midlerne for at genoprette konkurrenceevnen, om end ikke på verdensmarkedet, så dog på det indenlandske marked. Oplysningerne om den effektive beskyttelsestold i Vesttyskland viser også en korrelation mellem effektive handelsbarrierer og betydningen af lønudgifter i de enkelte industrigrene. Således udgør den effektive toldbetkyttelse for tekstilindustriens produkter ca. $21 \%$, for beklædningsindustrien ca. $22 \%$, for NE-metalindustrien ca. 25\%. Uden disse toldforanstaltninger havde kapitalrentabiliteten i de nævnte grene sikkert været endnu lavere. Men hertil kommer endnu noget som betegner situationens modsigelsesfuldhed: Nogle brancher i den vesttyske kapital er henvist til høje exportkvoter; mens andre brancher må beskytte sig mod »billigimport« gennem handelsbarrierer. Men i længden bliver også exporten truet af importbarrieren, da importen - om end ikke alene - påvirker andre landes betalingsdygtighed. Men ved ophævelse af handelsbarriererne kommer de pågældende vesttyske brancher i økonomiske kriser.

Derfor bliver den anden strategi så meget desto vigtigere, nemlig at flytte selve vareproduktionen til såkaldte lavtlønslande. For BRD forekommer den antagelse os plausibel, at nogle traditionelle industrigrene som tekstilindustrien, beklædningsindustrien, læderforarbejdning, dele af den finmekaniske og optiske industri og den elektrotekniske industri næppe vil kunne forsvare bastionen i Vesttyskland overfor konkurrencen fra de såkaldte lavtlønslande uden effektiv toldbeskyttelse. For mulighederne for en yderligere omkostningsbesparende substitution af arbejde med kapital bliver begrænset sålænge som en meget arbejdsintensiv produktionsmåde i mange regioner på jorden medfører $\varnothing$ konomiske fordele p.gr.a. de meget lave lønninger. Således er det i de næste år sandsynligt, at den tendens, der i stigende grad har kunnet iagttages siden 1969, til også at exportere pengekapital med det formål at oprette produktionssteder i lavtlønslandene vil fortsætte. Især bliver følgende produktioner ramt, fordi lønudgifternes andel af produktionen er meget høj: tekstiler, beklædningsartikler, elektrotekniske og elektroniske produkter, finmekaniske og optiske produkter. De industrier, der fremstiller disse produkter, bliver koncentreret i enkelte regioner på jorden, i Sydøstasien, i de såkaldte »frie industrizoner«, f.eks. i Sydkorea og Taiwan, Singapore eller Mexico.

Disse tendenser antyder, at der med tiden vil udvikle sig nye branchestrukturer. Arbejdsintensive produktionsprocesser bliver tendentielt flyttet til lavtlønslande, hvorimod kapitalintensive produktionsprocesser vil forblive i de højtudviklede kapitalistiske lande. Således skriver Gerhard Fels: »at en branche er mere konkurrencedygtig i arbejdsdelingen, desto mere kapitalintensivt den producerer, fordi lønforskellen er mindre relevant ved kapitalintensiv produk- 
tion ... Mens udviklingslandene har konkurrencefordele ved produktioner, der kræver mindre fastkapital og mindre kvalificerede arbejdskræfter end andre produktioner $\aleph^{114}$. Af den følgende figur 7 kan man iagttage branchernes struktur i overensstemmelse med deres rangfølge i kapitalintensitet og styklønsudgifter. Ved første blik er det påfaldende, at kapitalintensitet og styklønsudgifter i høj grad korrelerer negativt, dvs. at en høj kapitalintensitet modsvarer en relativ lav lønandel af nettoproduktonsvolumen og omvendt. Dette kan forklares dermed, at kapitalintensiet og arbejdsproduktivitet i reglen korrelerer positivt. En høj arbejdsproduktivitet betyder jo, at lønningernes andel af produktions resultatet (i vor sammenhæng: nettoproduktionsvolumen) er relativ ringe i forhold til den i markedspriser værdisatte brugsværdimasse. Fra en høj arbejdsproduktivitet i en branche og tilsvarende lav lønandel af nettoproduktionsvolumen (som fremstillet) kan man dog ikke slutte til en tilsvarende høj branchemerværdi, som det f.eks. sker hos Zschocke ${ }^{115}$. Merværdiraten kan kun totalsamfundsmæssigt bestemmes gennem arbejdskraftens reproduktionsomkostninger, dvs. produktivitetsudviklingen i hele $\varnothing$ konomien. Men når man går ud fra hele økonomien, så må nødvendige overvejelser om forholdet mellem produktivt og uproduktivt arbejde anstilles, som vi har forsøgt det i del 3.3.2.

Af de fire kvadrater er vi kun interesseret i den første og den tredje. Når de karakteriserede tendenser til at omstrukturere brancherne efter udenrigshandelen bliver virksomme, så skulle de især ramme de brancher, der ligger i det tredje kvadrat, altså de der opviser en forholdsvis høj lønandel ved samtidig relativ lav kapitalintensitet. Dette gælder naturligvis kun omtrentligt; nærmere oplysning herom kan man kun opnå gennem en brancheanalyse, der går i detalje. Det kan også være, at kun den arbejdsintensive del af produktionen bliver flyttet som det allerede er sket indenfor den optiske industri i Vesttyskland, mens de processer, der kræver kapitalintensitet og høje kvalifikationer, bliver drevet videre i Vesttyskland ${ }^{116}$.

Konsekvenserne af disse omstruktureringstendenser for arbejderklassen kan allerede nu iagttages. For det første opstår der tendenser til branchespecifik og regional arbejdsløshed. For det andet bliver der udøvet tryk på lønningerne. For det tredje bliver dekvalificerings- og rekvalificeringsprocesser fremtvunget.

114. G. Fels, Der Wandel der weltwirtschaftlichen Arbeitsteilung und seine Konsequenzen für die Branchenstruktur der westdeutschen Wirtschaft, i: WSI-Studien, nr. 22, Köln 1973.

115. H. Zschocke, op.cit., s. 102f.

116. Det kendteste eksempel for det er Rollei. Mens den tekniske udvikling og andre processer, der kræver højt kvalificeret personale, bliver drevet i Vesttyskland, finder den arbejdsintensive produktionsted under gunstige lønforhold i Singapore. De kameraer, der bliver produceret der, er ikke bestemt for det nære- og fjernøstlige, men frem for alt for det vesttyske marked. Den billige arbejdskraft udligner endog de extra transportomkostninger. 


\section{Figur 7:}

Korrelation mellem kapitalintensitet og styklønsomkostninger i den vesttyske industri.

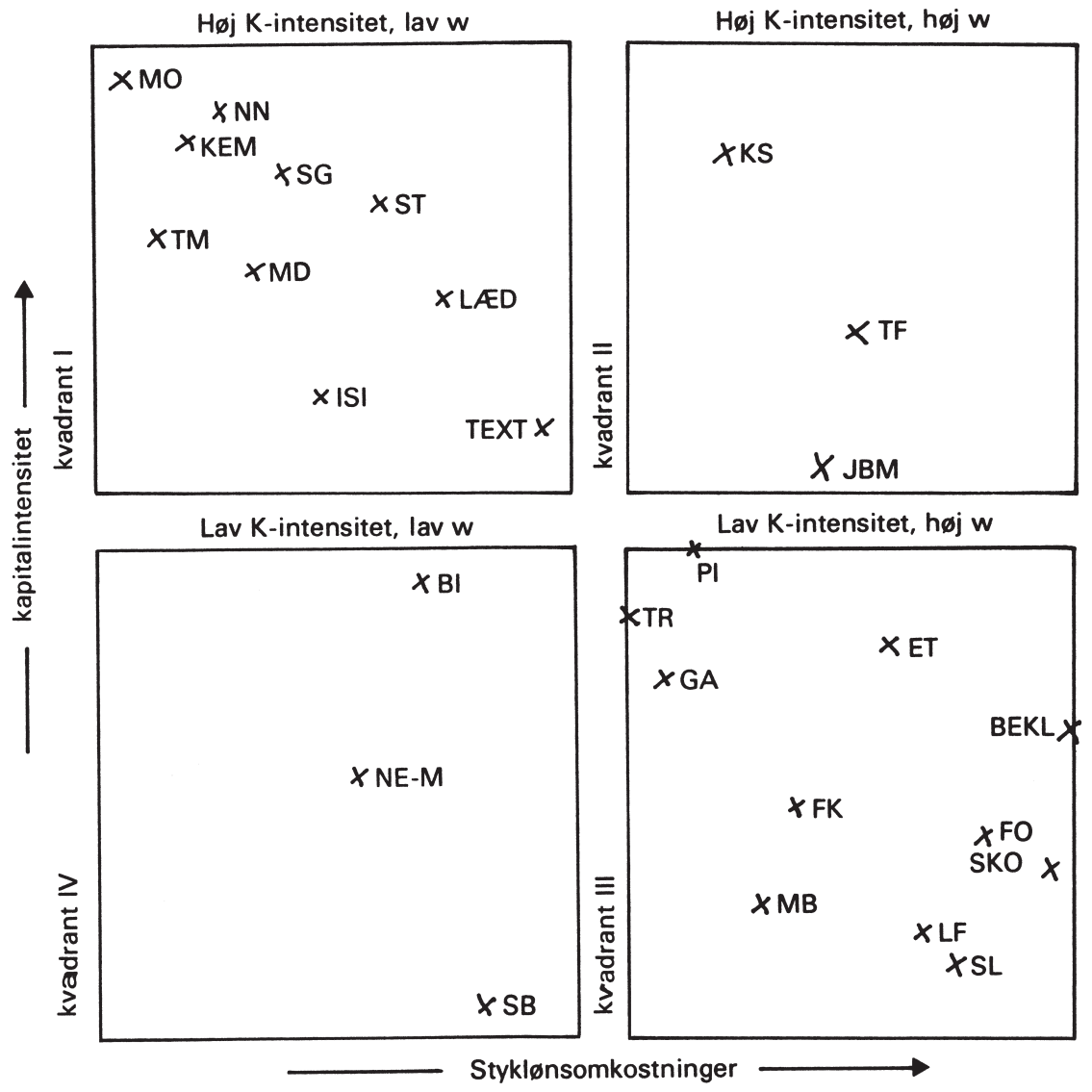

Signaturtegn for forkortelse af industrigrene: $\mathrm{MO}=$ mineralolieindustri; $\mathrm{NN}=$ nærings- og nydelsesmiddelindustrien; KEM = kemisk industri; $\mathrm{SG}=$ sten, grus m.v. industri; $\mathrm{ST}=$ savværk og træ-

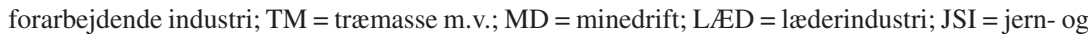
stålindustri; TEXT = tekstilindustri; TF = træforarbejdning; JBM = jern-, blik-, metalvareindustri; $\mathrm{PI}=$ papirindustri; $\mathrm{TR}=$ trykkeri; $\mathrm{ET}=$ elektroteknisk industri; $\mathrm{GA}=$ gummi- og asbestforarbejdning; BEKL = beklædningsindustri; FK = finkeramik; FO = fimmekanisk og optisk industri; NE-M = ikke-jern-metalindustri; SKO = skotøjsindustri; $\mathrm{MB}=$ maskinbygning; $\mathrm{LF}=$ luftfart $\varnothing j \mathrm{j}$ industri; SL = stål- og letmetalanlæg; SB = skibsbygning; $\mathrm{BI}=$ bilindustri; $\mathrm{KS}$ = kunststofindustri.

Kilde:

Egne beregninger, data fra $R$. Krengel, o.a., op. cit; w = styklønsomkostninger. 


\section{De nuværende betingelser for kapitalakkumula- tionen i BRD.}

Efter at vi har fremstillet tendenserne for kapitalakkumulationen i de forgangne år, kan vi forsøge at angive de grundlæggende udviklingstendenser for de næste år. Dermed gør vi på ingen måde krav på at opstille en prognose for kapitaludviklingen, snarere drejer det sig om at fremstille de $\varnothing$ konomiske nødvendigheder, som arbejderbevægelsen og de politiske organisationer for arbejderklassen i Vesttyskland står overfor, såvel som materialistisk at bestemme deres handlingsspillerum. Vi vil i den forbindelse gå frem som hidtil og undersøge de faktorer, der har indflydelse på kapitalrentabilitetens bevægelse. Allerede ud fra resultaterne af denne undersøgelse kan der drages bestemte slutninger med hensyn til handlingsspillerum. Men til yderligere konkretisering vil det være nødvendigt at udvide unders $\varnothing$ gelsen med flere aspekter og områder - et forehavende, hvis nødvendighed vi ud fra beskrivelsen af de åbne problemer kan klargøre, uden i denne artikel at kunne indfri disse krav.

1. Den langsigtede stigning i kapitalintensiteten, der i afgørende grad har bestemt den langsigtede tendens for kapitalvaloriseringen i Vesttyskland, vil også fremover blive afgørende for kapitalens udvikling. Dette er ikke alene resultatet af de særlige betingelser for kapitaludviklingen, som de især har været fremherskende i BRD - det vil vi straks gå ind på -, men af immanente lovmæssigheder for produktionsmåden. For kapitalen stiller sig overfor lønarbejdet i den stoflige form, der modsvarer dens begreb: maskineriet $\mathrm{i} \gg d e n$ store industri«, altså som konstant kapital. Dermed gør den sig uafhængig af alle begrænsninger ved arbejdskraften, hvad enten de nu er af psykisk eller fysisk natur, eller resultatet af arbejdets sociale karakter, der ikke fuldt ud er under kapitalens kontrol. Da kapitalen er et samfundsmæssigt forhold og selvom kapitalen er subjekt i bevægelsen i den kapitalistiske produktionsmåde, så er den dog ikke et autonomt subjekt, der er uafhængig af lønarbejderklassens interesser og kampe. Denne autonomi forsøger den netop at skaffe sig i den tendentielle substitution af arbejde med kapital; for maskineriet har ingen psyke, er fremmed for arbejdstidbegrænsninger og strejker. Heraf kommer det, at kapitalen, idet den gennem substitution af lønarbejde med kapital vil undgå modsigelsen og arbejderklassens særlige interesser, principielt producerer en ny modsigelse, der finder sit udtryk i kapitalens stigende tekniske sammensætning eller i stigende kapitalintensitet.

Denne almene tendens finder sikkert ikke nogen betydningsfuld historisk modadgående virkning i de kommende år i Vesttyskland - så som en dyb økonomisk krise, der radikalt og voldsomt ville mobilisere de ellers ikke virksomme modtendenser. Hvis vi foreløbigt ser bort derfra, viser sig følgende billede: 
For det første lader det ikke til, at produktionsprocessens organisation kan ændres så betydeligt, at det nødvendige kapitalindskud til konstant kapital på denne måde afgørende vil kunne forringes ${ }^{117}$.

For det andet vil kapitalen også i fremtiden være tvunget til at »substituere « arbejdskraft med maskineri; for arbejdsvolumen vil kun stige ubetydeligt ${ }^{118}$, mens yderligere en $h \varnothing j$ lønkvote vil forstærke rationaliseringsinvesteringer som $»$ konomisk fornuftige«. Produktivitetsstigninger vil derfor kun opnås gennem forhøjelse af kapitalintensiteten, dvs. gennem anvendelse af »arbejdsbesparende « metoder i produktionsprocessen ${ }^{119}$.

For det tredje, og denne faktor angår ikke blot den fixe kapital, men hele den konstante, vil den del af den konstante kapital, der må tilvejebringes til $k \emptyset b$ af råstoffer og energi, ikke gå tilbage i de næste år i betragtning af de verdensomspændende stigende råstofpriser ${ }^{120}$. De stigende råstofpriser har altså ikke kun betydning for kapitalen i metropolerne derved, at milliardbel $\varnothing \mathrm{b}$ af pengekapital og betalingsmidler flyder til de råstofproducerende lande (især til de olieproducerende lande), hvad der stærkt belaster forbrugerlandenes betalingsbalance, men også derved, at udlæggene til konstant kapital tilsvarende stiger og følgelig forhøjer den organiske sammensætning. (Også arbejdskraftens produktionsomkostninger bliver af denne grund forøget, fordi råstofpriserne, der indgår i arbejderklassens konsumtion, stiger).

2. Arbejdsproduktiviteten, således kan man slutte ud fra vore hidtidige overvejelser, kan sikkert ikke ved den fremherskende tvang til kapitalintensivering af produktionen hæves i den grad, at den negative effekt ved stigningen i kapitalintensiteten vil kunne udjævnes af kapitalrentabiliteten. Dvs. kapitalkostabare metoder til stigning i arbejdsproduktiviteten vil også være bestemmende i 70'erne. For selv en arbejdsorganisatorisk »optimalisering « af produktionsprocessen, der omfatter såvel den økonomiske anvendelse af c (konstant kapital) som også intensiveringen af arbejdet, er ikke ubegrænset muligt. Netop nyere undersøgelser har vist, at med den »fremherskende mekaniseringsgrad « bliver grænserne for stigningen i arbejdsproduktiviteten tydelig $^{121}$, mens en yderligere intensivering af arbejdet bliver umuligt såvel p.gr.a. grænsen for den fysiske belastning af arbejderne. som p.gr.a. arbejdernes afværgekampe mod forringede arbejdsbetingelser. Også i 70'erne vil den

117. Jvf. RKW-Forschungsprojekt, 7 Bericht, op.cit. s. 82. »(Man kan) i reglen gå ud fra, at (under bestemte tekniske betingelser, forf.) udformes produktionsforløbet så rationelt, at ingen organisatoriske fremskridt længere kan nås «. På den anden side er ifølge RKW-Berichtsband det tekniske niveau (mekaniseringsgraden) atter væsentlig afhængig af den herskende lønsats.

118. Jvf. ibid., s. $22 f$.

119. Jvf. ibid. s. 36 .

120. Jvf. artiklen af Masserat og Tamassebi i: Probleme des Klassenkampfs nr. 11/12 (1974).

121. Jvf. RKW-Berichtsband, op.cit., s. 82 (Jvf. fn. 117). 
såkalete struktureffekt blive uden stor betydning ${ }^{122}$. Derimod bliver den kontinuerlige fulde udnyttelse af kapaciteterne endnu mere nødvendig end tidligere på grund af stigningen i kapitalintensiteten, der samtidig indbefatter en stigning $\mathrm{i} »$ fixomkostningsandelen «, selv om »kapitaludgiften pr. produkt « stiger hhv. kapitalproduktiviteten falder (hvad vi påviste for 60'erne). ${ }^{123}$. Netop den faldende kapacitetsudnyttelse i enkelte brancher, for tiden cyklisk mere forstærket, vil i de næste år ${ }^{124}$ begrænse stigningen $\mathrm{i}$ arbejdsproduktiviteten.

3. Resultatet af denne proces vil med stor sandsynlighed være en også fremover faldende kapitalproduktivitet. For at denne proces ikke skal slå negatovt igennem på kapitalrentabiliteten, er der for den vesttyske kapital kun den udvej at sænke styklфnsomkostningerne. Denne sammenhæng kan man også udtrykke anderledes: Når en forhøjelse af merværdiraten ved hjælp af arbejdets stigende produktivkraft vil være sværere i 70'erne end i årene før, for at kompensere den nødvendige stigende organiske kapitalsammensætning, så vil kapitalen vende tilbage til at forhøje merværdiraten gennem politisk begrænsning af lønraten. Denne almene sammenhæng er det, der begrunder de mangfoldige foranstaltninger af indkomstpolitik - fra »konzertierten Aktion « (samordnet indgreb) over mobilisering af den borgerlige offentlighed mod fagforeninger, politimæssig undertrykkelse af strejkebevægelser til statslig skattepolitik.

4. Når vi sagde, at profitraten hhv. kapitalrentabiliteten er faldet i de forgangne år og yderligere vil falde, så gælder dette på ingen måde for profitmassen. Den høje udbytningsrate af lønarbejderne sørgede for, at profitten, som de produktive lønarbejdere producerede, forøgedes hurtigt. Hvis man udregner stigningen i bruttogevinsterne, så når de med udgangspunkt i 1950 (=100) i 1960 en værdi af 176 og i 1970 en værdi af 551, dvs. de forøgedes med mere end det femdobbelte. I betragtning af denne udvikling kunne man tale om, at »profitmassen opvejer profitraten « og derfor ville det være relevant $\mathrm{i}$ vurderingen af de fremtidige udviklingstendenser for den vesttyske kapital mindre at inddrage den forventede profitrateudvikling end udviklingen i profitmassen. Denne antagelse holder dog kun stik i begrænset omfang. For kun allerede bestående store kapitaler kan være tilfreds med profitmassen uden at skulle sammenligne deres egen valoriseringssituation med andre kapitaler. Men en sammenligning kræver stadigvæk, at resultatet - profitmassen - kan sættes i forhold til omkostningerne ved at opnå den (det samlede kapitalindskud), dvs. profitraten kan lægges til grund herfor.

Men når en enkelt kapital kalkulerer med alternative anvendelsesmuligheder for den producerede profit til akkumulerbare fonds, så bliver profitraten igen vigtig; den er og bliver under kapitalistiske forhold »produktionens stimu-

122. Jvf. RKW-Forschungsprojekt, bd. 2, op.cit., s. 58.

123. RKW-Berichtsband, op.cit., s. 122: På grund af den stigende »fixomkostningssokkel « forekommer »kravet om fuld udnyttelse af anlæggene ... endnu mere påtrængende end før«. Jvf. også vores fremstilling af den $\varnothing$ konomiske verdenskrise.

124. Jvf. Monatsberichte der Deutschen Bundesbank, oktober 1974. 
lerende ild «. Store kapitaler, hvor profitmassen endnu kan opveje profitraten, akkumulerer i begrænset omfang. Modsigelserne bliver med det sagtnede akkumulationstempo snarere skærpet; for klassemodsigelserne tilspidses. Men når profitraten falder så meget, at der fra den voksende profitmasse ikke længere industrielt vil kunne anbringes nogen tillægskapitaler til den hidtidige profitrate, så synes kapitalen at være overflødig, at være »overakkumuleret«.

Før vi kan gå ind på dette, må vi i det mindste nævne en fremtrædelse, der hænger smmen med den stigende profitmasse. Som vi har set er kapitaludgifterne pr. arbejdsplads steget enormt. Dermed var nødvendigvis forbundet en voldsom koncentrations- og centralisationsproces af kapital, der fremfor alt efter krisen i 1966/67 har antaget et hidtil ukendt omfang. Koncentrationen og centralisationen af kapital udtrykker sig for det første i den langsigtede tendens til, at andelen af selvstændige kapitalister i forhold til det samlede antal af erhvervsaktive kontinuerlig aftager, nemlig fra 31,6\% i 1950 til $15,6 \%$ i 1972. Næsten $85 \%$ af alle erhvervspersoner er altså lønarbejdere, hvis produktive del producerer en stigende profitmasse. For det andet har også koncentrations- og centralisationsprocesserne en cyklisk forløbsform. Dette er en konsekvens af den kendsgerning, at kapitalen forsøger at klare valoriseringsvanskelighederne med koncentrationsforanstaltninger. Ledsagsfremtrædelser og udtryksformer for koncentration og centralisation er derfor regelmæssige rationaliseringer i produktion og cirkulation, virksomhedsstandsninger for at »sanere « produktionsprogrammer, fallitter og virksomhedsovertagelser af større koncerner, dvs. kapitaltilintetgørelsesprocesser, produktionsflytninger til andre regioner. For det tredje er det her afgørende, at tendensen til koncentrations- og centralisationsprocesser fører ud over de nationale grænser og til internationalisering af produktion og cirkulation. Der opstår også i Vesttyskland internationalt agerende koncerner - med de modsvarende konsekvenser for kapitalens totalreproduktionsproces ${ }^{125}$. Det bliver en væsentlig fremtrædelse, at med kapitalens internationalisering bliver forskellene i de nationale reproduktionsmuligheder, især forskellene $\mathrm{i}$ lønhøjde, i skattelovgivning og i rentefodens højde udnyttet for totalt at få en højere profitrate af den i forskellige nationer indskudte kapital, end det ved et nationalt begrænset aktionsfelt ville være muligt.

Dermed er vi allerede ved konsekvenserne af den faldende kapitalrentabilitet, som allerede antydedes i 60'erne, men som i 70'erne opnår en stærkere betydning. I denne sammenhæng vil vi kun gå ind på fire punkter, nemlig akkumulationsbevægelsens cykliske forløbsform, tendenserne for pengekapitalexporten, oprindelsen til en industriel reservearme, indkomstpolitik for at sikre kapitalens valorisering.

125. Jvf. bl.a. K. Busch, Multinationale Konzerne - op.cit. 


\subsection{Akkumulationsbevægelse og krisecyklus}

De cykliske krisefremtrcedelser, der også i 50'erne og i første halvdel af 60 'erne optræder med betegnende regelmæssighed, dog kun som afsvækkelse i væksten, er blevet forstærket til manifest krise. Recessionen i 1966/67 var efter vores interpretation så stærk, fordi de tendenser, der virkede mod profitratefaldet, nu kun kunne mobiliseres periodevis gennem en dybtgribende »renselse « af valoriseringsvanskelighederne. Ved hjælp af det udførlige citat fra det $\emptyset$ konomiske råd (i afsnit 3.3.3.) har vi vist de vigtigste renselsesprocesser, der virkede gennem krisen. Også ud af de statistiske oplysninger kan det uddrages, at krisen fremskyndede tilvækstraterne for arbejdsproduktiviteten, sagtnede væksten i kapitalintensiteten og for en tid sænkede lønstyksomkostningerne. Alt $i$ alt fulgte heraf - som det let ses af figur 3 - en positiv virkning på kapitalrentabiliteten. Det er altså intet under, at der efter krisen kunne udfolde sig et nyt voldsomt boom i kapitalakkumulationen. Men de grundlæggende modsigelser i kapitalakkumulationen kunne kun reduceres, men ikke ophæves og således måtte nødvendigvis opsvinget lede over i en stagnationsfase og endelig en ny, sværere krise - som vi nu oplever.

Denne krisecyklus i kapitalakkumulationen kunne kun fremtræde som en række af »vækstscykler « ${ }^{126}$ så længe som vækstsraterne og kapitalrentabiliteten tilsammen var høje, dvs. de modsigelser, der er tilgrundlæggende for væksten, endnu ikke var tilspidset. Siden de tendenser, der virker mod profitratefaldet (høj udbytningsrate, formindskelse af kapitalens organiske sammensætning, mobiliserbare produktionsreserver uden større kapitalindskud osv.) har mistet deres kraft i selve kapitaludviklingens proces, så kan disse tendenser kun mobiliseres i krisen. Et nyt opsving har derfor krisen som forudsætning. Fordi vi kan angive, hvilke modsigelser det drejer sig om at klare, kan vi også angive krisens grundlæggende forløbsform: Kapitaludgiften må sænkes gennem tilintetgørelse af kapital såvel i brugsværdiform (virksomhedsstandsning, ophugning af anlæg osv.) som i værdiform (konkurser, særafskrivninger, prisfald osv.); arbejdsproduktiviteten må forøges gennem intensivering af arbejdet, som i krisen er det mest probate middel for kapitalens rationalisering, for såvidt ingen nyanlæg kræves af kapitalen; styklønsudgifterne må sænkes gennem reducering af lønningerne, altså gennem »nedsættelse af levestandarden ${ }^{127}$, gennem nedsættelse af virksomhedsmæssige og offentlige sociale ydelser osv. Hvordan denne proces i detalje vil udfolde sig, kan vi dog svært vurdere. for det afhænger væsentlig af statslige indgreb og arbejderklassens reaktioner og dens organisationer.

126. Jvf. Undersøgelserne af Hopp, Wagner, Bombach, Sachverständigenrat, der taler om vækstcykler.

127. Jvf. Helmut Schmidt, cit. i Frankfurter Rundschau d.4.10.1974: Levestandarden falder, »de vesteuropæiske industristaters befolkninger må efter Forbundskansler Helmut Schmidts mening finde sig i en sænkelse af levestandarden...« 
Hvis vor analyse passer, hvis der i 70'erne ikke er nogen muligheder for den vesttyske kapital for at forøge arbejdsproduktiviteten uden kapitalintensivering, og også hvis styklønsudgifterne ikke i tilstrækkelig grad kan falde, så er det kun sandsynligt, at der opstår periodiske kriser. Nu er en $\varnothing$ konomisk krise ikke slet og ret en episode i kapitalakkumulationens forl $ø b$, men et dybtgående snit ikke blot i kapitalvaloriseringens proces, men i alle samfundsmæssige områder og forbindelser. Forhøjelsen af arbejdsproduktiviteten er ikke kun en økonomisk formel, men en reel proces, der griber hårdt ind i arbejds- og produktionsbetingelserne. Sænkningen af styklønsomkostningerne er ikke en egentlig omkostningsdæmpning, men indeholder en forandring i fordelingsforholdet af det producerede værdiprodukt til fordel for kapitalen og til skade for lønarbejdet. Dette kan derfor ikke finde sted uden sociale stridigheder og kampe.

\subsection{Verdensmarkedsindflydelse}

At den vesttyske kapitals kriseagtighed, hvis cykliske forløbsform vi her har opridset og som har sin årsag i akkumulationstendenser i 60'erne, endnu ikke tidligere er fremtrådt i stærkere grad, skylder den vesttyske kapital sin stærke stilling på verdensmarkedet. Den stærke efterspørgsel efter vesttyske varer på verdensmarkedet bevirkede først og fremmest, at reproduktionsprocessens kontinuitet blev sikret. Det var således muligt for den vesttyske kapital at gennemføre en udvidet reproduktion og en stigning i arbejdets produktionskraft gennem udvidelsen af de udenlandske markeder, uden at en sådan stigning i produktionen var begrænset af efterspørgselsforholdene. Dette blev netop tydeligt, da det nationale marked indsnævredes i de cykliske kriser (som i krisen i 1966/67), mens den ubrudte efterspørgsel efter vesttyske varer i udlandet reducerede krisens mulige omfang. Vi kan fastslå denne betydning af verdensmarked for alle cykliske nedgangne i Vesttyskland. Denne stærke stilling muliggjorde også at den vesttyske kapital kunne betale fordyrelsen af råstofindførslen gennem en forstærket export af varer - på bekostning af de lande, der importerede disse varer. Denne stærke stilling på verdensmarkedet virker »desarmerende « også i den aktuelle krise (1974/75), hvad der særligt viser sig i enkelte brancher som stål- og kemiindustri. Således er - trods revalueringen exportoverskuddet i Vesttyskland i 197333 mia. DM højere end nogen sinde tidligere siden 1967. Også i 1974 fortsætter denne tendens. Alene fra januar til august i 1974 udgør overskuddet på handelsbalancen 32,8 mia. DM.

For det høje exportoverskud og den absolutte og relativ betydningsfulde produktion af varer til det ydre markedet er to momenter afgørende: For det første profitable produktionsbetingelser i indlandet og for det andet gunstige realiseringsbetingelser på verdensmarkedet. Da produktionsbetingelserne - ligesom det er blevet fremstillet i vores hidtidige fremstilling - er blevet forringet i BRD p.gr.a. den faldende valoriseringsgrad, men da realiseringsbetingel- 
serne for den vesttyske kapital på verdensmarkedet stadigvæk er usædvanlig gode, medfører det, at der siden slutningen af 60'erne, ved siden af den stærke export, er en tendens til at exportere den overflødige pengekapital i forventning om at kunne opnå en højere profitrate i udlandet end i indlandet.

Denne forstærkede interesse for at anbringe kapital i udlandet er ganske vist blevet fremkaldt af »billiggørelsen« af kapitalanbringelse i udlandet som fulgte med DMs opskrivning ${ }^{128}$. Men derudover har de forandrede betingelser for profitproduktionen i Vesttyskland medført en forskydning i forhold til verdensmarkedet. Var exporten af varekapital indtil slutningen af 60'erne alene dominerende, så sætter der sig åbenbart også efterhånden en forstærket export af anbringelsessøgende pengekapital igennem.

Grunden til denne forskydning er den relative forringelse af mulighederne for kapitalanbringelse i produktionssfærerne, der fremstiller varer til afsætning i det indre og ydre marked. (Dermed menes på ingen måde, at produktionen af varer allerede har været uprofitabelt for kapitalen).

For ved siden af den hidtidige fremherskende motivation for pengekapitalexport, nemlig at sikre og udvide exportmarkederne, sætter tendenser til at flytte selve produktionsprocessen sig stærkere igennem siden begyndelsen af 70'erne: Dele af produktionsprocessen, der er »kapitalintensiv«, bliver gennemført i indlandet og andre dele, der er »arbejdsintensiv«, bliver flyttet til såkaldte lavlønslande. En sådan omplacering kan ikke kun betragtes under aspektet den »interne « kapitalrentabilitet, men må også ses i sammenhæng med den internationale arbejdsdeling. For verdensmarkedskonkurrencens virkning på de brancher, der allerede tidligere blev karakteriseret som »arbejdsintensive« og i hvilke lønnen er en relativ vigtig faktor i kostprisen, medfører en skærpelse af kapitalens rentabilitetskrise i disse brancher. Som vi allerede har fremført, er den antagelse plausibel, at arbejdsintensive industrigrene og/eller arbejdsintensive produktionsområder (dele af tekstil- og beklædningsindustrien, dele af ESBM-forarbejdningen, den finmekaniske og optiske industri, den læderforarbejdende industri) næppe kan opretholde deres bastion i BRD. Den relative høje toldbeskyttelse og de forholdsvis lave lønninger - i 1970 er timelønnen for arbejdere i gennemsnit af den samlede industri 6,95DM; i minedrift 8,76DM, i elektroteknisk industri 6,46DM, i finmekanisk og optisk industri 6,05 DM, i læderforarbejdningen 5,03 DM, i tekstilindustrien 5,72DM og i beklædningsindustrien 4,94 DM (»Kvindearbejde « $)^{129}$ - er ganske vist en vis beskyttelse for verdensmarkedskonkurrencen fra lavlønslandene. Men da lønandelen tilsammen overfor fixkapitalens andel af kostprisen er meget stor, betyder lønforskelle meget. De arbejdsin-

128. Den gennemsnitlige opskrivningssats for DM over for valutaerne i den samlede vestlige verden i slutningen af november 1973 er i sammenligning med slutningen af 1969 22,4\%, over for dollaren $39,8 \%$ og over for Pund Sterling 43,1\%.

129. Statistisches Jahrbuch 1971, s. 206 egne beregninger. 
tensive industrigrene er derfor før end andre brancher tvunget til at skifte stadeplads, fordi deres kapitalrentabilitet gennem lønbesparelser - lønniveauets forskellighed mellem udviklede og underudviklede lande - vil kunne opretholdes eller endog forhøjes ved omplacering til »lavlønslande«. For så vidt kapitalintensive industrigrene ligeledes flytter deres produktion eller dele af deres produktion skyldes det, at arbejdsproduktiviteten ikke yderligere kan (i store spring) forøges ved teknisk modnede og standardiserede produktionsmetoder, mens produktionsmetoderne tillader indsatsen af ukvalificeret arbejde. Også indenfor disse brancher - elektroteknik, optisk og finmekanisk industri - vil en omplacering af produktionen under de nævnte betingelser hæve kapitalrentabiliteten ${ }^{129 a}$.

\subsection{Overakkumulation og arbejdsløshed}

Vor analyse har vist, at der for BRD empirisk kan påvises en tendens til overakkumulation af kapital, som åbenbart finder sin pendant i andre vigtige kapitalistiske lande; dér oven i købet forstærket gennem nationale strukturkriser, forringet stilling på verdensmarkedet (valutaproblemer etc.) og skærpede klassekampe. Ved overakkumulation af kapital forstår vi her ikke kun udvidelsen af produktionskapaciteten i forhold til en i ringere grad stigende »effektiv efterspørgsel «. Snarere forstår vi herunder det fænomen, at en yderligere kapitalanbringelse giver aftagende profit, kapitalvaloriseringen falder, hvorved nyanlæg af kapital bliver indskrænket, og følgelig stagnerer eller falder også »investeringsefterspørgslen «, pengekapital bliver ikke anvendt til produktive anlæg, men flyder ud på »penge- og kapitalmarkedet«. Overakkumulation er derfor kun bagsiden af den faldende profitrate. Det

129a. En profitabel anbringelse af produktiv kapital st $\varnothing$ der derimod indenfor den industrialiserede kapitalistiske verden (EF, USA og Japan) på stigende vanskeligheder, selvom kapitaleksport p.gr.a. forskydelsen mellem de enkelte lande eller inden for de enkelte brancher vil være fornuftigt hhv. udvikler sig til det (Eksempler er de i senere år forstærkede investeringer i automobilindustrien og kemiindustrien i USA og andre højt udviklede kapitalistiske lande). Disse direkte investeringer har en anden karakter end investeringer i lavlønslandene. De er ikke fors $\varnothing \mathrm{g}$ på undvigelse fra høje lønninger, men er fors $\emptyset \mathrm{g}$ på for det første at få fodfæste på exportmarkederne med produktionsanlæg i det tilfælde, at handelsforhindringerne indskrænker vareexporten, og for det andet $\mathrm{i}$ betragtning af olieprisstigningerne at formindske de enormt stigende transportomkostninger. Disse kapitalexporter beror så at sige på »gensidighed «; for andre kapitalistiske lande må, for at kunne opnå og udvide positionen på det vesttyske marked, også investere direkte. Dette er endog i forhold til den vesttyske pengekapitalexport den - i det mindste kvantitativ - mere betydningsfulde eksistens. For lige så typisk som de permanente exportoverskud på handelsbalancen er de permanente overskud af pengekapitalimporten på kapitalomsætningsbalancen. Blot kan man ikke over for den globale udvikling af pengekapitalomsætningen negligere den nye tendens for den vesttyske kapital til pengekapitalexport med det formål at oprette produktionsanlæg i »lavlønslandene «. 
er en omskrivelse af en overflod af kapital, der ikke længere kan anbringes produktivt, fordi den ikke længere kan opnå en »passende « profitrate, selvom store koncerner endnu kan udvide kapitalen p.gr.a. de høje profitmasser, som disse koncerner tilegner sig.

Overakkumuleret kapital eksisterer i alle kapitalformer:

- som ikke sælgelig varekapital (f.eks. de ikke sælgelige bilbjerge i BRD)

- som ikke udnyttet produktivkapital (således er den vesttyske kapitals kapaciteter kun udnyttet ca. 80\% i anden halvdel af 1974);

- som overflødig »vagabonderende« pengekapital, da den ikke kan tilbageforvandles til produktiv kapital (den eksisterer f.eks. på Europengemarkedet som spekulationspenge og er en permanent urofaktor på det internationale pengemarked).

Overakkumulation af kapital omfatter altså forandring i reproduktionsforbindelserne, et fald i efterspørgslen efter produkter fra afdeling I (produktionsmidler). Overakkumulation af kapital kan også gøre sig gældende som indskrænkning i kapitalisternes og arbejdernes konsumtion (p.gr.a. faldende profit, faldende reallønninger og arbejdsløshed) hvilket medfører, at efterspørgslen efter konsumtionsmidler også falder, hvilket igen berører de samlede efterspørgselsforhold. Overakkumulation er altså også fald i den »effektive efterspørgsel «.

På den anden side betyder dette arbejdsløshed, fordi udvidelsen af produktivkapitalen ikke længere sker i tilstrækkeligt omfang. Kapaciteterne bliver således uudnyttet og kapitalen tvinges til pengemarkedet og kriseforstyrrelsen inden for penge- og kreditvæsnet griber fat $\mathrm{i}$ andre områder.

Lægger vi disse almene sammenhænge, der passer for BRD, og de i den forgangne fremstilling påviste påvirkninger fra verdensmarkedet til grund, så kan vi - bortset fra den cykliske industrielle reservearme - fastslå tre med hinanden formidlede årsager til dannelsen af arbejdsl $\phi$ sheden i BRD i den aktuelle $\phi k o-$ nomiske udvikling:

(1) som udtryk for overakkumulation af kapital, faldende kapitalvalorisering, ringere kapitalanbringelse og produktionsindskrænkning; karakteristisk herfor er arbejdsløsheden, der er forstærket gennem nedgangen i cyklen, $\mathrm{i}$ investeringsvareindustrien (især i metalindustrien);

(2) som såkaldt »teknologisk « arbejdsløshed, der skyldes det »arbejdsbesparende tekniske fremskridt « dvs. frisættelse af arbejdskræfter gennem forandring i kapitalens sammensætning, uden at de frisatte arbejdere igen har kunnet absorberes gennem udvidelsen af produktionen

(3) som arbejdsløshed, der opstår af den strukturelle krise i de enkelte brancher, som vi tidligere har kendetegnet som »arbejdsintensive« og som særligt er truet af verdensmarkedskonkurrencen (tekstil- og beklædningsindustri, sko- og lædervareindustri) 
Figur 8:

Arbejdsløse og ledige stillinger 1969-1974.

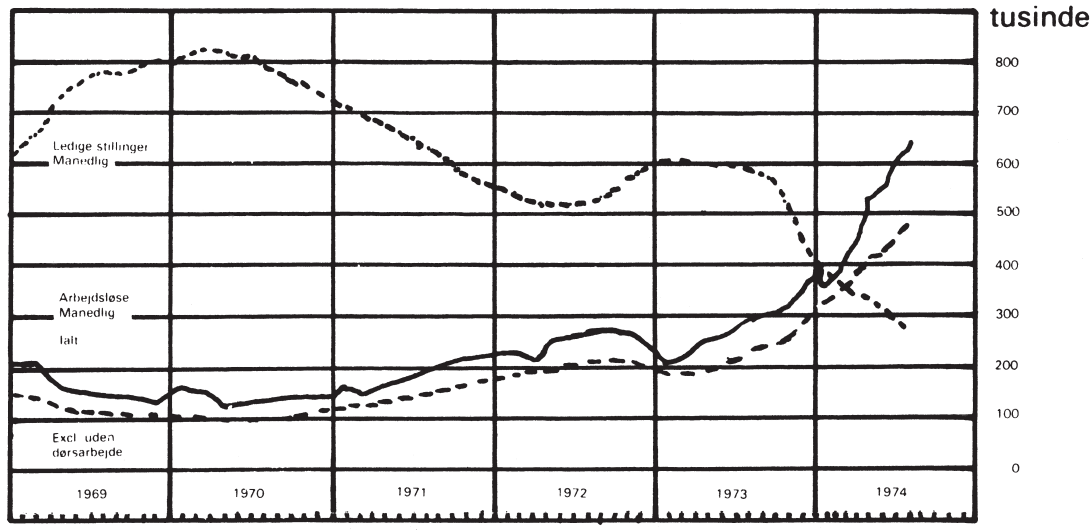

1. Såvel som andre stærkt sæsonafhængige erhverv.

Kilde:

Statistische Beihefte zu den Monatsberichten der Deutschen Bundesbank, Reihe 4: Saisonbereinigte Wirtschaftszahlen, Nr. 8 (August 1974), s. 5.

Men den nuværende »arbejdsløsheds« omfang (jvf. vores figur 8, som dog slet ikke udtrykker den aktuelle tilspidsning i slutningen af 1974) er væsentligt bestemt af, at det ikke længere er muligt for kapitalen (p.gr.a. sin valoriseringssituation) at akkumulere acceleret i en sådan grad, at de arbejdere, der er blevet frisat gennem rationaliseringsinvesteringer og strukturkriser, igen kan indlemmes i den kapitalistiske produktionsproces. Investeringsniveauet viser sig at være for lavt. En sådan antagelse bliver bekræftet gennem den borgerlige konjunkturforskning, der konstaterer, at nettoinvesteringerne går tilbage og forstærket »rationaliseringsinvesteringer « bliver foretaget: »Investeringsudgifterne har ganske vist (1974 forf.) værdimæssigt tiltaget lidt, men det kunne væsentligt tilbageføres til prisstigninger på investeringsvarerne. Efter volumen gik sæsonrenset udstyrinvesteringerne tilbage i andet kvartal af 1974; de har nu i de sidste 4 år bevæget sig (!) ... på et og det samme niveau. Virksomhedernes tilbageholdenhed med nye investeringer skulle ikke mindst forklares ud fra, at gevinstmarginerne i økonomien er kommet under stadig stærkere tryk « ${ }^{130}$.

Med den stigende arbejdsløshed og den vedvarende inflation er et dilemma dog under opsejling for den statslige økonomiske politik: »Postulatet om fuldbeskæftigelsespolitik « kommer mere og mere i konflikt med den fors $\varnothing$ gte fastholden af en politik om »pengeværdistabilitet«, omvendt, selv ved (relativ) høj arbejdsløshed falder raten for pengeværdiformindskelsen ikke længere.

130. Monatsberichte der Deutschen Bundesbank, september 1974. 


\subsection{Dilemmaet for den statslige økonomiske politik ${ }^{131}$}

Siden midten af 60'erne har den statslige $\varnothing$ konomiske politik først og fremmest fors $\emptyset$ gt at overvinde krisen i 66/67; tilsyneladende med held og det syntes at give de kritikere af den marxistiske kriseteori ret, der gik ud fra en principiel autonomi for den senkapitalistiske stat overfor $\varnothing$ konomien og som hævdede, at staten kunne styre $\varnothing$ konomien. Men den statslige regulering af krisen i 66/67 havde sin materielle årsag i, at under og efter krisen gjorde de årsager, der modvirker faldet i kapitalrentabiliteten, sig igen gældende og staten kunne i sin politik knytte an til netop disse modvirkende momenter og fremskynde disse, uden at den i dette tidsrum samtidig fyrede op under inflationen med »deficitspending «. Men samtidig kunne den ikke ophæve de tendenser der ligger til grund for akkumulationsprocessen; stadigvæk stiger kapitalintensiteten i det følgende tidsrum hurtigere end arbejdsproduktiviteten og - med kortere afbrydelse - falder kapitalproduktiviteten og kapitalrentabiliteten. Heraf kommer det, at disse tendenser i skærpet grad gør sig gældende i 70'erne; med det igen indtrufne fænomen af cyklisk overakkumulationskrise og standsende kapitalakkumulation og stagnation.

Derved viser det sig, at arbejdsløsheden i 70'erne fremtræder stærkere end i krisen 1966/67. Er derfor statsapparatet (af politiske grunde) tvunget til »anticykliske interventioner « mod udviklingen af arbejdsløsheden og forsøger det at standse den proces af kapitaltilintetgørelse, der sker i krisen, så fremtræder på den anden side mere og mere inflationaere processer, der bliver fremmet gennem anvendelsen af instrumenter i den statslige politik (deficit-spending, billiggørelse af penge- og kreditoptagelse, begunstigelse af kapital-, handelsog konsumentkriser). Men gennem inflationen bliver den statslige »beskæftigelsespolitik « igen begrænset.

Vi kan ikke her gå nærmere ind på årsagerne til den »permanente inflation«, det må blive forbeholdt senere undesøgelser. Men vi kan her godtgøre, at den modgift, som den statslige $\varnothing$ konomiske politik foranstalter mod den statslige $\varnothing$ konomiske politiks »modgift « mod den inflationære udvikling: fordyrelse af penge- og kreditoptagelse, formindskelse af statsudgifterne, yderligere begrænsninger af massekonsum gennem lønbegrænsning (»statslig indkomstpolitik «) ${ }^{132}$ ikke blot er relativ virkningsløs mod inflationen, men samtidig også forstærker de tendenser, der fører til braklægning af kapital og til arbejdsløshed. (Bortset fra, at den statslige restriktionspolitik kan modarbejdes af de store enkeltkapitaler gennem muligheden for kreditoptagelse i udlandet).

131. Vi vil i en kommende artikel forsøge akkumulationsteoretisk at undersøge de nuværende inflationære processer på basis af vores empiriske analyse. Her vil vi derfor ikke gå nøjere ind på inflationen og dens forklaring.

132. Jvf. dertil J. Hoffmann, W. Semmler, Kapitalreproduktion, Staatseinflüsse auf den Arbeitslohn und Gewerkschaften, referat på kongressen for Deutschen Vereinigung für Politische Wirtschaft i Hamburg, 1-4. oktober 1974, Politische Vierteljahresschrift. Sonderheft 1974. 
I dette dilemma, som den statslige politik er i, bliver det - på den økonomiske bevægelses overflade - tydeligt, at staten ikke autonomt kan styre og regulere akkumulationsbevægelsen, men er indviklet i kapitalproduktionens lovsmæssigheder. I sidste insstans er den statslige politik netop afhængig af profitproduktionens og akkumulationens betingelser. Sålænge keynesianske illusioner endnu kunne være fremherskende, nemlig at produktionen efter (politisk) forgodtbefindende kunne sættes igang gennem efterspørgselsstyring, syntes antagelsen om en autonomi for staten at være begrundet. Men så snart den formindskede profitrate begrænser mulighederne for keynesiansk reguleringspolitik, kommer den statslige økonomiske politik i vanskeligheder: Det »kan (nemlig) godt være, at selv en tilbagevenden til et højt økonomisk aktivitetsniveau ikke ville have til resultat at hæve profitraten til niveauet for den tidlige efterkrigsperiode... I dette tilfælde har den $\varnothing$ konomiske politik, der er bestemt til at fremme væksten gennem de private investeringer, en svær opgave for sig... $\ll^{133}$.

Staten er altså indfanget lige som selve kapitalen i produktionsmådens modsigelser. Dens kvalitet som kriseregulator for kapitalen følger blot af, at staten kan fremskynde og afkorte mange processer, ligesom den er et politisk magtinstrument, der formår at undertrykke de sociale konflikter, der viser sig i krisen og som kan true kapitalens eksistensmåde. Staten undgår derfor ikke krisen, men den sætter den på spidsen, idet den med sine politiske midler skærper den $\varnothing$ konomiske voldsomhed i dens løsning (sammenbringelse af »modstridende agentier «). Alt efter de muligheder som lovmæssighederne sætter for staten og alt efter de politiske betingelser for det herskende partis apparat vil den politisk formidlede kriserenselse forløbe hurtigt og brutalt eller langsomt. Kapitalakkumulationens cykliske krise kan staten altså ikke forhindre; den kan kun fremskynde dens rensende funktion og dermed fremme krisens værk.

Det ovenfor beskrevet dilemma kan staten derfor kun unddrage sig, idet den påvirker kapitalens profitbetingelser, forbedrer den disse. Ganske vist bliver den statslige indkomstpolitik begrundet ud fra den påståede sammenhæng mellem lønstigninger og prisstigninger; men denne lønbegrænsnings-politik sigter mod - set fra produktionssiden - at stabilisere profit og profitrate.

Efter at den keynesianske $\varnothing$ konomiske politik således er »slidt op«, aftegner der sig en tilbagevenden til de neoklassiske instrumenter for den økonomiske politik under de betingelser, en faldende kapitalrentabilitet stiller, nemlig lønbegrænsninger, undertrykkelse af fagforeniner og af spontane lønstrejker osv. Samtidig accepteres en vis underbeskæftigelsesrate, som på »klassiske « måde skal inddæmme lønudviklingen: En »naturlig arbejdsløshedsrate« bliver propaganderet som løsningen på kapitalvaloriseringens krise, mens indkomstpo-

133. R. M. Solow, Capital Theory and the Rate of Return, Amsterdam (North-Holland Publishing Company) 1963, s. 93. 
litikken i denne sammehæng endnu kun har »flankerende« funktion, nemlig at holde den »uomgængelige « beskæftigelsestilbagegang, der er nødvendigt for at genvinde stabiliteten, i skak ${ }^{134}$.

\section{DEN RØDE LISTE}

Nyhedsbulletin for venstrefløjens udgivelser.

Følg med i venstrefløjens udgivelser:

DEN RODE LISTE udkommer én gang om måneden, undtagen i juli. Den indeholder oplysninger om bøger, pjecer, plakater, foldere, større lobesedler, duplikater, nye tidsskrifter, særnumre/temanumre af tidsskrifter, film, plader og kassettebånd.

Send bud efter et prøvenummer ved indsendelse af $3 \mathrm{kr}$. i frimærker eller abonner straks:

Et årsabonnement ( 11 numre) koster:

Enkeltpersoner ........................................ kr. 50,-

Bogcafeer/organisationer/grupper .................. kr. 75,Biblioteker/institutioner .............................. kr. 125, -

Abonnementet løber fra sidstudkomne nummer, medmindre andet er oplyst på girotalonen. (Nr. 21975 er udsolgt).

DEN RODE LISTE / TIDSSKRIFTCENTRET Rådhusstræde 13 stuen, 1466 København K.

Giro 32828 21. Tel. (01) 129949 (12.30 til 17.30) 


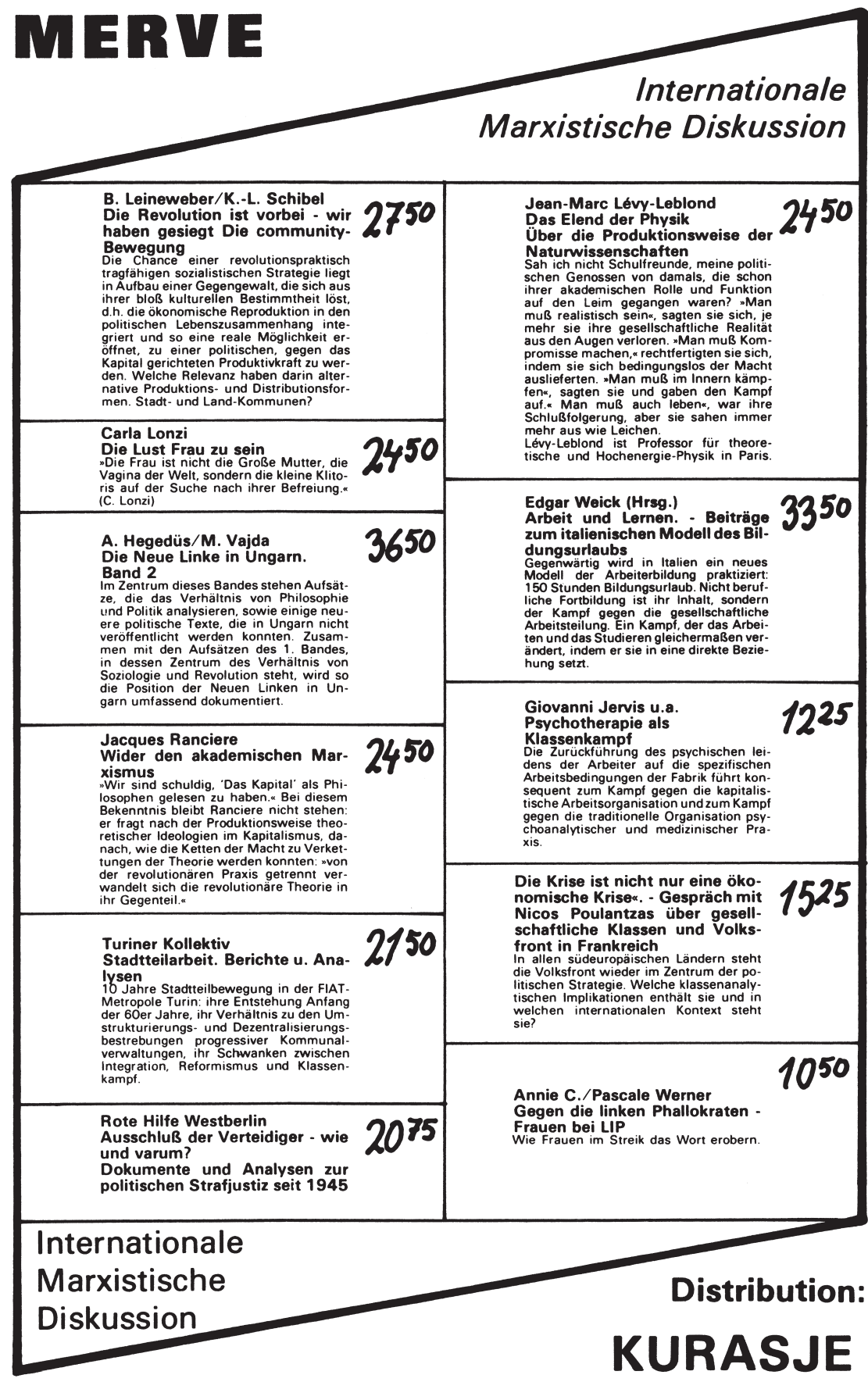




\section{tidsskrift for universitets- og forskningspolitik}

\section{nordisk forum}

Nordisk Forum er et forsknings- og universitetspolitisk tidsskrift, udgivet af Nordisk Sommeruniversitet.

Tidsskriftet bringer analyser af universitets- og forskningspolitiske problemer, beretter om forsøg på at udvikle en progressiv praksis på universiteterne og andre forskningssteder, fremlægger diskussioner af teoretiske udviklingstendenser inden for enkelte forskningsområder og videregiver konkrete informationer om universitets- og forskningspolitik.

nordisk forum 1975

NF 5

Videnskabens arbejdsgivere og forskernes situation

\section{NF 6}

Forskning i samarbejde med arbejderbevægelsen

\section{NF 7}

Erhvervsorienterede universitetsreformer

\section{NF 8}

Tekniker-socialisering og teknisk uddannelse. Demokratisk styring og planlægning i arbejdslivet

abonnement 1975:

kr. 60,00

enkeltnumre, pr. nr:

kr. 18,50 nordisk forum 1976 NF 9

Pædagogik, uddannelsespolitik og uddannelsesforskning

NF 10

Samfundsplanlægning, forskning og social teknologi

NF 11

Om udviklingen i social- og sundhedssektoren (udk. oktober)

\section{NF 12}

Arbejdsmiljø, forskning og fagbevægelse

(udk. december)

abonnement 1976:

kr. 65,00

enkeltnumre, pr. nr:

kr. 19,50

Abonnement/enkeltnumre bestilles i boghandel/bogcafe eller ved indbetaling af abonnementspris/pris for enkeltnumre til

RUC BOGHANDEL \& FORLAG MARBJERGVEJ . DK 4000 ROSKILDE GIRO 3215431 